\title{
ECOLOGIA DE POPULAÇÕES DE ESPÉCIES DE Amaranthus L., QUE OCORREM NO ESTADO DE SÃO PAULO, BRASIL
}

MARIA DE FÁTIMA POLLASTRINI VARGAS

Orientador: Prof. Dr. PAULO SODERO MARTINS

Dissertação apresentada à Escola Superior de Agricultura "Luiz de Queiroz", da Universidade de São Paulo, para obtençāo do título de Mestre em Agronomia - Área de Concentração: Genética e Melhoramento de Plantas.

PIRACICABA

Estado de São Paulo - Brasil ..

Fevereiro, 1985 
O grande problema da rumanidade nao está no domínio da ciência, mas nos corações e mentes.

Einstein 


\section{AGRADECIMENTOS}

0 autor agradece o apoio recebido durante a realização do curso e deste trabalho, às seguintes pessoas e entidades:

Professor Doutor Paulo Sodero Martins, pela seriedade em sua posição de orientador;

Conselho Nacional de Desenvolvimento Cientifico e Tecnológico - CNPq, pelo auxilio financeiro durante uma parte da realização do curso;

Empresa Brasileira de Pesquisa Agropecuāria - EMBRAPA, pelo auxilio financeiro durante o curso; .

Meus pais, pelo incentivo e confiança na con clusão deste trabalho;

Maria Lūcia Carneiro Vieira, pelo carinho com que me ofereceu sua ajuda, tornando possivel a concretização deste trabalho;

Itamar Soares de Mello, pelo interesse e apoio nas primeiras tentativas de anālise dos dados,

Senhora Angela Monnerat, pela datilografia dos manuscritos. 


\section{N D I C E}

T. INTRODUÇAO • . . . . . . . . . . . . . . 01

2. REVISAO de literatura . . . . . . . . . . . . 04

2.1. Aspectos botânicos do gênero Amaranthus. . 04

2.2. Aspectos históricos e potencialidades de algumas espécies do gênero Amaranthus . 13

2.3. Aspectos do crescimento vegetativo e reprodutivo . . . . . . . . . . 1.6

2.4. Fracionamento de energia . . . . . . 18

2.5. Caracterização da competição intraespecîfica " 23

2.6. Caracterização da competição interespecifica 27

3. MATERIAL E METODO • • . • . . . . . . . . 33

3.1. Determinação do ciclo vital . . . . . 33

3.1.1. Instalação do experimento . . . 33

3.1.2. Caracterização do crescimento vegetativo e reprodutivo de $A^{\circ}$. hybridus, A. retroflexus, A. spinosus. e A. viridis . . . . . . . . 34

3.1.3. Distribuição fracionāria de energia 35

3.2. Estudo de aspectos da dinâmica populacional 36

3.2.1. Instalação do experimento . . . . 36

3.2.2. Ensaio de densidade para caracterização da competição intraespecĩfica

3.2.3. Ensaio de competição para caracterização da competição interespecífica 
4. RESULTADOS E DISCUSSAO • • • • • • • • . 40 4.1. Determinação do ciclo vital . . . . . 40

4.1.1. Caracterização do crescimento vegetativo e reprodutivo de A. hybridus,

A. retroflexus, A. spinosus e A. viridis . . . . . . . . . . 40

4.2. Estudo de aspectos da dinâmica populacionai . 65

4.2.1. Estudo referente a populações naturais de A. hybridus e A. deflexus. . . 65

4.2.2. Caracterização da competição intraespecífica • . . . . . . . . 67

4.2.3. Caracterização da competição interespecîfica . . . . . . . . . . 69

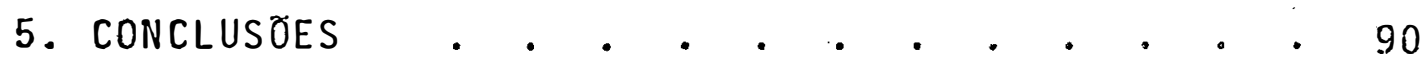

6. LITERATURA CITADA • • • . . . • • . . 9 92 


\section{LISTA DE TABELAS}

Tabela 1. Comprimento médio, em $\mathrm{cm}$, da haste principal e da intlorescência principal de 10 plantas duran te o ciclo vital de A. hybridus, A. retrofiexus, A. spinosus e A. viridis. Ensaio em vasos. Piracicaba, 1983.

Tabela 2. Medidas das taxas de crescimento calculadas a partir dos grāficos $3,4,5$ e 6 , considerando intervalos constantes de 10 dias, onde $V=S / T$, sendo $V=$ taxa de crescimento em $\mathrm{cm} / \mathrm{dia}, S=$ comprimento $(\mathrm{cm})$, $T$ = tempo (dias); calculados para haste principal e inflorescência de A. hybridus, A. retroflexus, A. spinosus e A. viridis. Ensaio em vasos. Piracicaba, 1983.

Tabela 3. Medidas do comprimento em $\mathrm{cm}$, refe rentes à haste principal, raiz e inflorescência, efetuadas apōs o término do experimento em condições de laboratório, para 10 plantas de A. hybridus, A. retroflexus, A. spinosus e A. viridis. Ensaio em vasos. Piracicaba, 1983. 
Tabela 4. Anālise da variância segundo delineamento inteiramente casualizado dos dados apresentados na tabela III. Ensaio em vasos. Piracicaba, 1983.

Tabela 5. Teste de Tukey aplicado aos dados $\underline{a}$ presentados na tabela 3 , utilizando valores de $\Delta$ a $5 \%$ e a $1 \%$ de probabilidade, onde letras iguais unem médias que não apresentam diferenças significativas.

Tabela 6. Medidas do peso seco em gramas, referentes a ramos + folhas, inflorescencias + sementes e raiz em 10 plantas de A. hybridus, A. retroflexus, A. spinosus e A. viridis e suas respectivas médias $(\bar{x})$ e coeficientes de variação (CV). Ensaio em vasos. Piracicaba, 1983.

Tabela 7. Anālise da variancia segundo delineamento inteiramente casualizado dos dados apresentados na tabela 6. Ensaio em vasos. Piracicaba, 1983.

Tabela 8. Teste de Tukey aplicado aos dados a presentados na tabela 6 , utilizando valores de $\Delta$ a $5 \%$ e a $1 \%$ de probabilidade, onde letras iguais unem médias que não apresentam diferenças significativas. Ensaio em vasos. Piracicaba, 1983:

Tabela 9. Dados referentes à alocação de ener gia, expressos em porcentagem (\%) de matēria seca, destinada a ramos + folhas, inflorescências + sementes e raiz, para 10 plantas de A. hybridus, A. retroflexus, A. spinosus e A.- viridis, com suas respectivas médias $(\bar{x})$ e coeficientes de variação (CV). Ensaio em vasos. Piracicaba, 1983. 
Tabela 10. Número total de plantas e número de $\mathrm{plantas} / \mathrm{m}^{2}$ observadas em quadrados de $1 \mathrm{~m} \times 1 \mathrm{~m}, 2 \mathrm{~m} \times 2 \mathrm{~m}$, $3 \mathrm{~m} \times 3 \mathrm{~m}, 4 \mathrm{~m} \times 4 \mathrm{~m}$ e $5 \mathrm{~m} \times 5 \mathrm{~m}$, em populações naturais de $\underline{A}$. de flexus e A. hybridus. Piracicaba, 1983.

Tabela 11. Peso seco e porcentagem de alocação de energia para ramos + folhas e inflorescências + sementes, em 5 plantas provenientes de populações naturais de A. deflexus e A. hybridus. Piracicaba, 1983.

Tabela 12. Dados médios de 3 repetições, refe rentes a número de plantas sobreviventes, peso médio por planta sobrevivente e porcentagem de sobrevivência nas densidades de semeadura de $6,12,24,48,96$ de A. deflexus. e A. hybridus. Ensaio em vasos. Piracicaba, 1983.

Tabela 13. Peso seco médio em gramas total, de ramos + folhas, inflorescēncias + sementes e raiz, de trēs repetições, obtidos a partir da média do número de sobreviventes de cada vaso em ensaio de densidade em vasos de A. deflexus. e A. hybridus. Piracicaba, 1983.

Tabela 14. Dados médios de 3 repetições relativas a porcentagem de alocação de energia, tomados a partir do peso em gramas, destinados a ramos + folhas, inflcrescēn cias + sementes e raiz, nas densidades de semeadura de 6 , $12,24,48,96$, em condições experimentais de vasos, para A. deflexus. e A. hybridus. Piracicaba, 1983.

Tabela 15. Dados médios de 3 repetições relativos a número de plantas e respectivas porcentagens de so brevivencia em ensaio de competição em vasos, de $A$. deflexus. (D) e $\underline{A}$. hybridus. $(H)$, onde $P_{0}=100 \% \mathrm{D}, P_{1}=75 \% \mathrm{D} 25 \% \mathrm{H}$ 
$P_{2}=50 \% \mathrm{D} \quad 50 \% \mathrm{H}, P_{3}=25 \% \mathrm{D} \quad 75 \% \mathrm{H}$ e $P_{4}=100 \% \mathrm{H}$, num total de 100 sementes para cada repetição. Piracicaba, 1983.

Tabela 16. Dados mëdios referentes a 3 repet $\underline{i}$ ções do peso seco em gramas de ramos + folhas, inflorescências + sementes e peso seco total obtidos em ensaio de com-

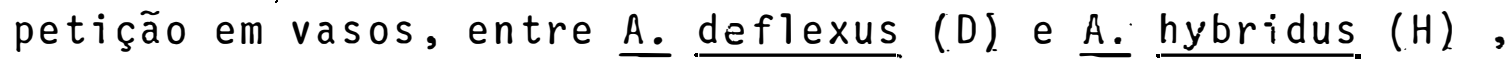
onde $\mathrm{P}_{0}=100 \% \mathrm{D}, \mathrm{P}_{1}=75 \% \mathrm{D} \quad 25 \% \mathrm{H}, \mathrm{P}_{2}=50 \% \mathrm{D} \quad 5 \mathrm{G} \% \mathrm{H}, \mathrm{P}_{3}=25 \% \mathrm{D}$ $75 \% \mathrm{H}, \mathrm{P}_{4}=100 \% \mathrm{H}$, num total de 100 sementes por repetição. Piracicaba, 1983.

Tabela 17. Dados mëdios referentes a 3 repeti ções da alocação de energia obtidos atravēs do peso em gramas para ramos + folhas e inflorescências + sementes, em en saios de competição em vasos entre A. hybridus (H) e A. deflexus (D), onde $P_{0}=100 \% \mathrm{D}, P_{1}=75 \% \mathrm{D} 25 \% \mathrm{H}, P_{2}=50 \% \mathrm{D}$ $50 \% \mathrm{H}, \mathrm{P}_{3}=25 \% \mathrm{D} 75 \% \mathrm{H}, \mathrm{P}_{4}=100 \% \mathrm{H}$, num total de 100 sementes por repetição. Piracicaba, 1983.

Tabela 18. Dados referentes ao cālculo da pro dutividade relativa da espécie A. defiexus (RD) \& A. hybridus $(R H)$, calculados a partir da seguinte fórmula

$$
R x=\frac{\bar{x} x}{V x}
$$

onde $\mathrm{Rx}$ = produtividade relativa da espécie $\mathrm{x}$ em gramas, $X_{X}=$ produtividade da espécie $x$ em mistura ( $\left.g\right)$, e $\mathrm{YX}_{\mathrm{X}}=$ produtividade da espécie $\mathrm{x}$ em mistura. A produtividade total relativa (PTR) é obtida através da soma dos valores RD + RH nas diferentes proporções de espēcies estudadas. En saio em vasos. Piracicaba, 1983. 


\section{LISTA DE GRAFICOS}

Gräfico 1. Curva de crescimento da haste principal em cm, de A. hybridus, A. retroflexus, A. spinosus e A. viridis, durante o ciclo vital. Ensaio em vasos. Piracica ba, 1983.

Gráfico 2. Curva de crescimento da haste principal e da inflorescéncia em cm, de A. hybridus, A. retrofle xus, A. spinosus e A. viridis, onde $V_{4}, V_{5} \ldots$ correspondem a taxas de crescimento da inflorescencia tomadas em $\mathrm{cm} / \mathrm{dia}$. Ensaio em vasos. Piracicaba: 1983.

Gräfico 3. Curva de crescimento da haste principal e da inflorescência em $\mathrm{cm}$, durante o ciclo vital de A. hybridus, onde $v_{1}, v_{2} \ldots$ correspondem às taxas de cresci mento da haste principal e da inflorescência, tomadas em -cm/dia. Ensaio em vasos. Piracicaba, 1983.

Gráfico 4. Curva de crescimento da haste principal e da inflorescência, em $\mathrm{cm}$, durante o ciclo vital de A. retroflexus, onde $v_{1}, V_{2} \ldots$ correspondem a taxas de crescimento da haste e da inflorescência, tomadas em $\mathrm{cm} / \mathrm{dia}$. Ensaio em vasos. Piracicaba, 1983.: 
Grāfico 5. Curva de crescimento da haste principal e da inflorescência, durante o ciclo vital de A. spino sus, onde $v_{1}, v_{2} \ldots$ correspondem às taxas de crescimento da haste principal e da infiorescência, tomadas em $\mathrm{cm} / \mathrm{dia}$. Ensaio em vasos, Piracicaba, 1983.

Gráfico 6. Curva de crescimento da haste principal e da inflorescência em $\mathrm{cm}$, durante o ciclo vital de $\underline{\text { A. }}$ viridis, onde $v_{1}, v_{2} \ldots$ correspondem a taxas de crescimento tomadas em cm/dia. Ensaio em vasos. Piracicaba, 1983.

Grāfico 7. Representação esquemätica da interseção dos dados referentes ao peso em gramas para ramos + fo lhas, inflorescências + sementes e raizes, em A. viridis, A. spinosus, A. hybridus e A. retroflexus. Ensaio em vasos. Piracicaba, 1983.

Grāfico 8. Representação esquemātica da interseção dos dados referentes a comprimento $(\mathrm{em} \mathrm{cm})$ para haste, inflorescência e raiz principais, em A. viridis, A. hybridus, A. spinosus e A. retroflexus. Ensaio em vasos. Piracicaba, 1983.

Grāfico 9. Comparação esquemātica da alocáąão de energia (\%) utilizando-se a média dos dados apresentados na tabela 9 e seus respectivos coeficientes de variação. En saio em vasos. Piracicaba, 1933.

Grāfico 10. Representação grāfica da média da porcentagem de sobrevivēncia de 3 repetiçóes, em ensaio de densidade em vasos de A. hybridus e A. deflexus, cujas densidades de semeadura foram $6,12,24,48,96$. Piracicaba, 1983. 
Gráfico 11. Gräfico comparativo do nūmero mēdio de plantas e peso mëdio por planta, referentes à mëdia de 3 repetições, em ensaio de densidade em vasos de A. defle xus e A. hybridus, cujas densidades de semeadura foram 6 , $12,24,48,96$. Piracicaba, 19.83.

Grāfico 12. Comparação grāfica da alocação de energia em porcentagem, obtida atravēs do peso seco médio de 3 repetições, nas densidades de semeadura em vasos, de 6 , $12,24,48,96$, para ramos + folhas, inflorescēncias + sementes e raiz, de A. deflexus e A. hybridus. Piracicaba, 1983.

Grāfico 13. Porcentagem de sobrevivēncia mēdia de 3 repetições ao finai do ciclo, em ensaio de competi ção em vasos de A. deflexus (D) e A. hybridus. (H), onde $P_{0}=100 \% \mathrm{D}, P_{1}=75 \% \mathrm{D} \quad 25 \% \mathrm{H}, \mathrm{P}_{2} 50 \% \mathrm{D} \quad 50 \% \mathrm{H}, \mathrm{P}_{3}=25 \% \mathrm{D} \quad 75 \% \mathrm{H}$ $P_{4}=100 \% \mathrm{H}$, num total de 100 sementes para cada repetição. Piracicaba, 1983.

Grärico 14. Produtividade média de matēria se ca total, em gramas, medida ao final do cicio, em ensaio de competição em vasos, de A. deflexus. (D) e $\underline{A}$. hybridus (H), onde $P_{0}=100 \% \mathrm{D}, \mathrm{P}_{1}=75 \% \mathrm{D} \quad 25 \% \mathrm{H}, \mathrm{P}_{2}=50 \% \mathrm{D} \quad 50 \% \mathrm{H}, \mathrm{P}_{3}=2.5 \% \mathrm{D}$ $75 \% \mathrm{H}$ e $\mathrm{P}_{4}=100 \% \mathrm{H}$, num total de 100 sementes para cada repe tição. Piracicaba, 1983.

Grāfico 15. Porcentagem mēdia da alocação de energia de 3 repetições, obtida atravēs do peso seco em gra mas, em ensaio de competição entre A. deflexus. (D) e A. hybridus. $(H)$, onde $P_{0}=100 \% D, P_{1}=75 \% \mathrm{D} \quad 25 \% \mathrm{H}, \mathrm{P}_{2}=50 \% \mathrm{D}$ $50 \% \mathrm{H}, \mathrm{P}_{3}=25 \% \mathrm{D} 75 \% \mathrm{H}, \mathrm{P}_{4}=100 \% \mathrm{H}$, num total de 100 sementes para cada repetição. Piracicaba, 1983. 
Grāfico 16. Comparação grāfica da produtividą de total relativa (PTR), produtividade relativa de A. hybri dus $(R x)$ e produtividade relativa de A. deflexus (Ry). Ensaio de competição em vasos. Piracicaba, 1983. 
ECOLOGIA DE POPULAÇOES DE ESPECIES DE AMARANTHUS L., QUE OCORREM NO ESTADO DE SÃO PAULO, BRASIL

Maria de Fátima Pollastrini Vargas

Paulo Sodero Martins

- Orientador -

RESUMO

Este trabalho discute aspectos da ecologia de populações de espécies de Amaranthus, encontradas no Estado de São Paulo, Brasil. Para tanto, são analisadas caracterís ticas do ciclo vital, fracionamento de energia em atividades vegetativas e reprodutivas e aspectos da competição intra e interespecifica das espēcies A. deflexus e A. hybridus, participantes da mesma estrutura populacional em condi ções naturais.

Através de ensaio em vasos, determinaram-se as taxas de crescimento, duração do ciclo vital, época de florescimento e modelo de alocação de recursos para ramos + foThas, inflorescênciatsementes e raízes das espécies A. hybri dus, A. retroflexus, A. spinosus. e A. viridis.

Para caracterizar a competição intraespecífica de A. hybridus e A. deflexus, foi feito ensaio de densidade em vasos, utilizando-se parāmetros como taxa de sobrevivência e alocação de recursos. No estudo da competição in terespecífica, foi feito ensaio por substituição em vasos, de acordo com modelo proposto por de Wit (1960).

os resultados obtidos indicaram semelhanças en tre as espécies A. hybridus e A. retroflexus na duração do 
ciclo vital e época de florescimento, enquanto A. spinosus caracterizou-se como a espécie mais tardia e $\underline{A}$. viridis como a espécie mais precoce. Valores de esforço reprodutivo fó ram elevados para A. hybridus, A. retroflexus e A. viridis, enquanto $\underline{A}$. spinosus apresentou valores comparativamente bai xos.

Em A. deflexus o aumento da competição intra específica implica num aumento dos recursos sendo alocados para atividades reprodutivas, enquanto o A. hybridus, nas mesmas condições, aloca mais recursos para atividades vegetativas. A severidade do "self-thinning" intraespecífico é mais intensa para 0 A. hybridus do que para 0 A. deflexus.

A anālise dos dados da competição interespecî fica mostrou que as duas espēcies demandam diferentes recur sos limitantes do ambiente para sua sobrevivência, sendo que o A. hybridus apresenta crescimento tipicamente vertical, conseguindo uma maior captura da energia solar e o A. defle xus, um crescimento do tipo radial, próximo ao solo e sendo sombreado pelas plantas de $\underline{A}$. hybridus. A severidade do "self-thinning" interespecifico foi maior para o A. deflexus que para o A. hybridus. 
POPULATION ECOLOGY OF AMARANTHUS L. SPECIES, OCCURRING IN THE STATE OF S. PAULO, BRASIL

Maria de Fátima Pollastrini Vargas

- Author -

Paulo Sodero Martins - Adviser

SUMMARY

This work discusses aspects of the population ecology of Amaranthus found in São Paulo State, Brazil. The characteristics of the life cycle, energy partitioning and characterization of intra and interespecific competition between $\underline{A}$. hybridus and A. deflexus were analysed. These species take part of the same populational structure under naturà conditions.

Through pot experiments, growth rates, life cicle duration and resource allocation models for branches + leaves, inflorescence + seeds and roots of A. hybridus, A. retroflexus, A. spinosus and A. viridis species were determined.

Observations under natural conditions showed that A. deflexus $_{\text {. }}$ and $A$. hybridus species take part of the same populational structure. Density test was performed to characterize the intraspecific competition using parameters as survival rate and resource allocation. For the study of interespecific competition a test was made by replacement in pots as proposed by de Wit (1960).

The results obtained reveal similarities 


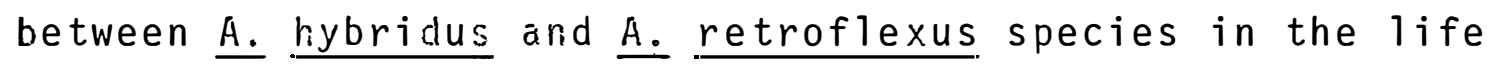
cycle duration and flowering time, while A. spinosus was characterized as the latest specie and $A$. viridis as the most precocius. The reproductive effort rates were high for A. hybridus, A. retroflexus, while A. spinosus comparatively showed low rates.

The increase in the intraspecific competition in A. deflexus implied on the increase of resources allocated for reproductive activities, while A. hybridus under the same conditions, allocated more resources for vegetative activities. The severity of intraspecific self-thinning was more intense in A. hybridus than in $\underline{A}$. deflexus.

The analysis of the interspecific competition data showed that the two species demand different limited resources of the invironment for their survival, being that A. hybridus presented a typically vertical growth with consequent large interception of solar energy and A. deflexus presented a radial growth close to the ground being shadowed by $A$. hybridus. The severity of interspecific self-thinning was larger for A. deflexus than for A. hybridus. 


\section{INTRODUÇAOO}

0 gēnero Amaranthus comporta cerca de 50 espēcies, distribuijdas preferencialmente pelas regiões tropicais do globo e, dentre estas espēcies, pelo menos uma deze na são invasoras cosmopolitas (Leitão Filho, 1968). Esta ca racterizaçăo do gênero possibilita antever a importância que este assume em relaçăo ao homem. Primeiramente, por ser um gênero de região tropical, onde estão situadas as populações humanas mais carentes e, em segundo lugar, devido a sua caracteristica invasora, competindo com culturas comerciais.

Por outro lado, estudos arqueológicos recentes, na América Central e Amērica do Sul, revelaram que algumas espēcies de Amaranthus têm estado associadas ao homem desde tempos pré-histōricos, sendo portanto, uma das plantas mais antigas cultivadas pelo homem. Este cultivo é data do de 4.800 A.C. (Pal e Khoshoo, 1974).

Dentre as potencialidades do grupo destacam- se a produção de grãos e folhas, sendo que as espēcies apresentam ciclo C4 de fotossintese e um crescimento rápido, completando seu ciclo vital em aproximadamente 90 dias. Anāa lise dos aminoäcidos contidos nas sementes de A: edulis revelaram conteúdo em 1 isina 23 a $30 \%$ maior do que no milho $\underline{0}$ paco-2, aproximadamente a mesma que apresenta a carne de so 
ja (Downton, 1973).

No que se refere à produção de folhas, Grubben (1976) enfatiza o valor do amaranto como excelente fonte de vitaminas $A$ e C. Altos niveis de oxalato e nitrato são algumas limitações para seu uso como hortaliça, mas alguns estudos têm mostrado que o consumo de $100 \mathrm{~g}$ ou menos por dia, não causa problemas dietēticos (Hauptli e Jain., 1980).

Os estudos deste grupo de plantas no Brasil, sao bastante escassos e aspectos referentes à ecologia de populações vêm acrescentar dados tanto no sentido do aprimo ramento de medidas de controle destas plantas, quando encaradas como ervas daninhas como tambēm, oferecer dados que auxiliem futuros trabalhos de melhoramento, visando o aproveitamento do potencial alimentar de algumas espécies do gènero.

A ecologia de populações pode ser analisada e interpretada sob três aspectos gerais: distribuição espacial e temporal dos individuos componentes da população, es tudos energëticos e dinâmica de populações. Apesar destes irês aspectos serem bem definidos, eles estão intimamente relacionados, principalmente quando se trata de populações. de plantas (Harper, 1977).

0 presente estudo foi realizado tendo como base os seguintes objetivos específicos:

a) determinar as caracteristicas do ciclo vi tal das espēcies A. hybridus, A. retroflexus, A. spinosus. e A. viridis:

b) comparar a distribuição fracionäria de energia entre estas espécies e associā-la a aspectos do ciclo vital e da arquitetura das plantas,

c) determinar aspectos da dinâmica populacio nal de A. deflexus e A. hybridus, no que se refere à compe- 
tição intra e interespecïfica, utilizando-se para tanto do enfoque da alocação de energia para atividades vegetativas. e reprodutivas. 
2. REVISAOO DE LITERATURA

2.1. Aspectos botânicos do gênero Amaranthus

o gēnero Amaranthus é cosmopolita, inciuindo plantas invasoras e cultivadas. Algumas espécies são consideradas daninhas, como A. spinosus L. em regiões tropicais, A. hybridus L., A. powellii. S. Wats e A. retroflexus L. em regiones temperadas. Entre as cultivadas, encontram-se pseidocereais, como A. caudatus L., A. cruentus L. e A. hypochondriacus L., hortaliças como A. tricolor L. e värias outras espécies ornamentais, isto $\overline{\bar{e}}$, formas ou raças pigmenta das dos três pseudocereais e de A. tricolor (Coons, 1981). Segundo Elias (1977), o teor mēdio de proteĩna encontrado nas sementes foi de $14,5 \mathrm{~g}$ e de $7,5 \mathrm{~g}$ de 1 ipídeos em $100 \mathrm{~g}$ de material analisado. Nos amarantos usados como hortaliça, foram encontrados valores médios de $3,6 \mathrm{~g}$ de proteinas e $0,5 \mathrm{~g}$ de lipídeos também em loog de material analisado.

Os problemas taxonömicos concernentes a este grupo de plantas são bastante complexos. Segundo. Sauer (1950), existem fatores básicos para esta complexidade. 0 primeiro deles é a ampla distribuição das espécies e as sutīs diferenças entre elas, o que leva, muitas vezes, uma es pécie a ser classificada diferentemente, quando esta ocorre 
em diferentes regiões.

0 segundo fator é um tanto mais complexo. Nas primeiras descrições botânicas, era dada importância a carac teres triviais como a pigmentação, além dessas descrições serem extremamente suscintas. Com a atribuição de maior importância às características florais na classificação, este problema foi, em parte, resolvido. As espécies foram descri tas e denominadas de acordo com regras, mas muitas ficaram completamente irreconhecīveis em relação as suas descrições originais, trazendo ainda mais complexidade aos" pröbtemas taxonömicos.

0 primeiro trabalho analisando caracteristi cas florais foi feito por Thellung (1914), utilizando-se de um cuidadoso estudo em herbārio. Posteriormente, Standley (1917), estudou o gênero para "Flora Norte Americana", prin cipalmente as espécies endēmicas da Amërica do Norte. O seu tratamento sistemātico dado à Seção Amaranthopypus. é nada mais que uma simplificaçäo do tratamento dado por Thellung (1914).

A seç̧ão Amaranthus inclue todos os grãos domesticados, corantes, ornamentais e muitas das ervas daninhas mais comuns, inclusive as pertencentes ao presente tra balho.

Baseando-se nos trabalhos de Sauer. $(1950$ e 1967), a seç̧ão Amaranthus distingue-se dentro do gênero pe las seguintes combinações de caracteres: plantas monóicas, cimeira continuando acima da folha superior para formar uma comprida inflorescência terminal, 5 tēpalas e estames (ou va riando entre 3 e 5 em flores de uma mesma planta), utrículo cir cunciso, sendo indeiscente em mutantes ocasionais e hibridos individuais. Alguns destes caracteres estão estreita- 
mente relacionados com o sucesso dos membros deste grupo co mo plantas invasoras, como hábito monōico, utrículo deiscen te levando a uma fäcil dispersão das sementes pelo vento e grandes inflorescências produzindo enormes quantidades destas.

As barreiras de cruzamento entre as espécies não são absolutas, mesmo quando estas apresentam diferentes nūmeros de cromossomos (Sauer, 1967). Há referēncias em 1iteratura (Pal e Khoshoo, 1973, 1974) à presença de hỉbridos envolvendo membros desta secção. A importāncia des tes hibridos, segundo Sauer (1967) tem sido exagerada, porque muitos são estéreis ou rapidamente eliminados pela sele ção natural. Entretanto, algumas ervas daninhas e populações cultivadas apresentam padrões de variaçã que sugerem efeti va introgressão (Coons, 1981).

O gēnero é polico estudado no Brasil, apesar de englobar plantas invasoras. Foi tratado originalmente na Flora Brasiliensis de Martius, sendo que esta classificação vem sendo revista mais recentemente. Há estudos feitos nos estados de São Paulo (Leitão Filho, 1968), Santa Catarina (Smith e Downs, 1972) e Minas Gerais (Coons; 1981).

Segundo Leitão Filho (1968), em seu trabaiho de descrição e caracterização das espēcies mais comuns do estado de São Paulo, as plantas do gēnero Amaranthus têm ci clo bastante curto, variāvel entre 60-j0 dias. Para a germi nação, necessitam temperaturas mëdias ao redor de $20^{\circ} \mathrm{C}$, de forma que, nos meses de maio, julho e agosto, praticamente não existe germinação de Amaranthus. No final da primavera e durante o verão ocorre a maior incidencia destas plantas, coincidindo com a época de máximo desenvolvimento vegetativo de diversas culturas anuais de grande importāncia economica, como amendoim e algodão e, por esta razão, as espécies de Amaranthus são bastante prejudiciais a estas culturas, neste periodo do ano. 
Bialoskorski e Martins (1981) constataram que a luz e a temperatura são fatores ecológicos de alta importância na germinação de algumas espécies de Amaranthus. Con dições de alternância de temperatura e ausência de luz indi caram um aumento de germinação em condições de teste de ger minação em cāmara ūmida para a A. hybridus, A. viridis, A. deflexus e A. hybridus subesp. cruentus. Uma grande variação tanto inter como intraespecífica foi observada.

Estes resultados permitem destacar fatores $1 \underline{i}$ mitantes para a colonização desta planta, uma vez que obterão um maior percentual de germinação aquelas sementes que, caindo no solo, estiverem protegidas da luz, ou, quando estiverem expostas à luz, estiverem sob choque térmico com temperacuras elevadas à superfície do solo.

As espēcies encontradas no Brasil e atê hoje descritas, são do tipo selvagem, caracterizadas por semen tes de coloração preta ou marrom escuro. Apresentam grande polimorfismo e são tipicas de locais abertos e alterados pe 10 homem. Sua grande plasticidade pode ser observada quando esta germina em rachaduras de muros e pequenos espaços aber tos nas calçadas.

Segundo Leitão Filho (1968), de uma forma geral, pode-se observar que o gênero Amaranthus tem marcada preferēncia por solos ricos e ūmidos, não aparecendo em áreas secas e āreas de cerrado. Baseando-se neste mesmo tra-balho de Leitão Filho (1968), serão descritas as espëcies $\underline{u}$ tilizadas neste estudó experimental.

A. hybridus L., Sp. P1. 990. 1753. Standley in North American Flora 21 pt 2:111, 1917.

Erva anual, ereta e pouco ramificada, de porte variāvel desde $30-40 \mathrm{~cm}$ até $130 \mathrm{~cm}$. Diâmetro da haste, na 
base, podendo atingir até $115 \mathrm{~cm}$ quando a planta atinge sua māxima dimensão.

Folhas simples, alternas, pecioladas, inteiras e com os bordos levemente ondulados. Limbo foliar gla bro, com a face interior mais clara e nervuras mais salientes. Folhas de dimensões variadas, atingindo de $3-20 \mathrm{~cm}$ de comprimento por $1,2-8,0 \mathrm{~cm}$ de largura. Forma foliar oval, oboval ou romboédrica, com extremidade subaguda.

Inflorescência terminal e axilar. A inflorescência axilar aparece apenas nas axilas das folhas superiores, onde surgem pequenos glomérulos de flores sésseis concrescidas, pēndula ou ereta, com tamanho variāvel de 8 - $9 \mathrm{~cm}$ até $35 \mathrm{~cm}$. Flor masculina com 5 tēpalas uniformes e lanceola das, ligeiramente acuminadas; flor com 5 estames, que possuem filetes longos maiores que as tēpalas. Flor femirina com 5 tépalas elipticas curtamente aristadas (principalmente as exteriores) que apenas se tocam, raramente uma encobrindo a outra, e de dimensões variadas (as exteriores geralmente maiores). O ovārio unilocular e uniovulado com 3 estigmas bem desenvolvidos e persistentes. A flor masculina 'e a flor feminina acham-se protegidas por 2 brācteas do tamanho ou pouco maiores que as tēpalas e ligeiramente arista das. Fruto pixidiforme com semente lenticular de coloraça pūrpura escura.

Pode-se, dentro da espécie, distinguir duas variedades muito comuns:

- variedade patulus (Bertol) Thell. Com inflo rescência verde e planta não pigmentada de antocianina..

- variedade paniculatus (L) Thell. Com toda a planta fortemente pigmentada de antocianina 
As duas variedades acima mencionadas são de $\underline{0}$ corrência muito comum no estado de São Paulo, principalmente em áreas de terra roxa. Näo poucas vezes, as folhas da variedade patulus. são usadas como verdura de mesa.

Amaranthus retroflexus L., Sp. P1. 991, Amaranthus hybridus L. subesp. cruentus (L) The 11 . in Aschers et. Graebn. Synopsis V. 1 p 236 (1914).

Erva anual, de porte ereto, variável entre 80 $-130 \mathrm{~cm}$. Plantas ramificadas desde a base, o que é muito caracteristico. Haste principal bem desenvolvida, com diāmetro de aproximadamente $1,5 \mathrm{~cm}$ na base e, no geral, pigmentada de antocianina.

Folhas simples, alternas, inteiras e pecioladas (com peciolo de tamanho variável entre 1,5-8,0cm). Limbo foliar glabro, de cerca de $4.12 \mathrm{~cm}$ de comprimento por 2,5 $-6,5 \mathrm{~cm}$ de largura. Folha de forma oboval ou romboédrica.

Inflorescéncia terininal e axilar. As inflores cências axilares são, no geral, pouco desenvolvidas, ao pas so que as inflorescencias terminais são bastante pronunciadas, atingindo em alguns casos, até $40 \mathrm{~cm}$ de comprimento.Mui to caracterïstico também, desta espēcie, é o fato de que, hạ vendo ramificações desde o colo da planta, aparecem diversas inflorescēncias terminais, uma na extremidade de cada ramificação. As inflorescēncias apresentam-se ligeiramente pigmentadas de antocianina.

Flores masculinas com 5 tépalas uniformes e ligeiramente acuminadas, flor com 5 estames com filete bem desenvolvido, de forma que as anteras são totalmente exclusas. Flores femininas com 5 tépalas, sendo que as 2 tépalas mais externas são maiores que as 3 outras e ligeiramente apiculadas. o ovário, unilocular e uniovulado com 3 estigmas. 
As flores, tanto masculinas como femininas, são protegidas por duas brácteas, cujo comprimento excede em pelo menos duas vezes o tamanho do perigônio (ou pouco menos), sendo que estas bräcteas assim desenvolvidas emprestam à inflores cência um aspecto caracteristico.

Fruto pixidiforme, com semente lenticular, es cura e brilhante.

Esta espécie é de difĩcil distinção no campo, onde, como elemento identificador, pode-se recorrer ao seu porte, a sua ramificação desde a base da planta e ainda, ao aspecto das inflorescências.

Amaranthus spinosus. L., Sp. P1. 991. 1753

Standley in North American Flora 21, pt 2:114 (1917).

Erva anual, de porte médio semi prostrado ou ereta, totalmente glabra, com haste verde escura, com ou sem antocianina e ligeiramente reluzente. A altura da haste é bastante variāvel, chegando algumas vezes atē $80 \mathrm{~cm}$, mas, no geral, com $50-60 \mathrm{~cm}$.

Folhas simples, inteiras, alternas e pecioladas, com peciolo de tamanho variāvel desde $1 \mathrm{~cm}$ até $4 \mathrm{~cm}$ de comprimento. Na base do peciolo encontram-se 2 espinhos intra axilares, resistentes, de 0,3-1,0 cm de comprimento, característico da espécie.

Inflorescência terminal e axilar. A inflorescência axilar é formada por glomérulos de flores sésseis, quase que, na sua totalidade, constituído de flores femininas de tamanho reduzido. A inflorescencia terminal, que pode atingir atē $13 \mathrm{~cm}$ de comprimento, é formada igualmente por glomérulos de flores sésseis; os glomérulos inicialmente são independentes, mas da metade para o āpice da inflo - 
rescência säo confluentes.

Perigônio da flor masculina formado por 5 tépalas lanceoladas, que protegem 5 estames nitidamente exclu sos. Perigonio da flor feminina formado por 5 tépalas de ta manho variado, que protegem o ovārio unilocular encimado por 3 estigmas. Tanto a flor feminina como a masculina são protegidas por 2 brácteas menores que as tépalas.

Fruto seco e deiscente, com semente escura e lenticular. Espécie comum como invasora, preferindo terrenos sujos. E das espécies mencionadas neste trabalho, a que melhor se adapta a terrenos secos, embora tenha preferéncia por solos ricos e ümidos.

Amaranthus viridis L., Sp. PJ. ed.2, 1405 $(1963)$

Erva ereta, de porte médio, atingindo até $70 \mathrm{~cm}$ de altura, embora no geral, seu tamanho oscile entre 40-50cm. Diānetro da haste, na base, variāvel, atinge o māximo de $1,0 \mathrm{~cm}$. A haste é glabra, com pouca ou nenhuma antocianina; embora este carácter seja variável, não é raro encontrar plantas bastante pigmentadas. Folhas simples, alter nas, pecioladas, com pecĩolo de tamanho variável desde $0,5 \mathrm{~cm}$ até $6,0 \mathrm{~cm}$. Limbo das folhas glabro e com bordos ondulados, variando o comprimento de $1,5-2,0 \mathrm{~cm}$ até 8,0 a $10,0 \mathrm{~cm}$. Fo1has de coloração verde escura, combordo inferior mais cla ro e com nervuras salientes.

Inflorescência terminal e axilar formada por glomérulo de flores sésseis. As inflorescências axilares são de pequeno porte, com apenas flores femininas. A inflores cência terminal é de tamanho variāvel desde $7,0 \mathrm{~cm}$ até $17,0 \mathrm{~cm}$, com flores masculinas e femininas. A inflorescência, 
com a maturação dos frutos, exibe aspecto encarquilhado mui to caracteristico. Flor feminina formada por 3 tépalas lanceoladas e livres, do tamanho ou pouco menores que o ovário. ovário coroado por 3 estigmas hialinos. Flor masculina com 3 tépalas uniformes e sub iguais, com extremidades ligeiramente acuminadas. Estames em nūmero de 3, com filetes curtos, de forma que as anteras são parcialmente exclusas.

Fruto seco, indeiscente, com exocarpo rugoso, caracteristico. Semente escura e lenticular, ligeiramente fosca.

Espēcie bastante comum em āreas de cultura do café, algodão e amendoim. Tem marcada preferência por solos de terra roxa e por locais ümidos.

Amaranthus deflexus L., Mant. 295. Willd.

Hist. Amar. 10 nọ $10 \mathrm{fig} 20$.

Erva de pequeno porte, no geral prostrada (ou raras vezes ereta, então com $30-40 \mathrm{~cm}$ de altura) e totalmente glabra. Raizes avermelhadas, pigmentadas de antocianina enquanto o resto da plarta quase nunca apresenta pigmenta ção. Folhas simples, alternas, pecioladas (com peciolo de tamanho variável entre $1,0-5,0 \mathrm{~cm})$. Limbo foliar glabro e a parte apical das folhas apresenta-se quase sempre perfeitamente excisa.

Inflorescência terminal, não se notando a não ser nas axilas das folhas superiores, algumas inflorescên cias não excedendo a $10 \mathrm{~cm}$ de comprimento, formada por flores masculinas e femininas, intercaladas, predominando as masculinas nas extremidades e as femininas nas porções intermediārias e basal.

Flor masculina com 3 tēpalas e lanceoladas, 
que protegem os estames que são exclusos. Flor feminina com 3 tépalas de extremidades ligeiramente arredondadas que pro tegem um ovārio unitocular e uniovulado coroado com 3 estig mas. Fior masculina e flor feminina săo protegidas por 2 brácteas pequenas, menores que as tépalas.

Fruto seco, indeiscente com exocarpo liso ou ligeiramente rugoso.

Espēcie comum em lugares sombreados e ümidos, tendo marcada preferência pela cultura cafeeira, embora ocorra em culturas de algodão, amendoim e hortaliças. Aparece ainda em solos de vārzea.

2.2. Aspectos históricos e potencialidades de algumas. espécies do gēnero Amaranthus

Estudos arqueológicos recentes, na Amërica Central e América do Sul, revelaram que os grãos de amarantos têm ěstado associados ao homem desde tempos pré-históri cos, sendo portanto uma das plantas mais antigas cultivadas pelo homem. Este cultivo é datado de 4.800 A.C. (Pal e Khoshoo, 1974l.

Estas evidências permitem destacar a importān cia que este grupo assume para a compreensão das etapas seguidas pelo homem na sua conquista do controle da produção de alimentos.

Por outro lado, de uma maneira mais especifica, permite um contato mais intimo com a histōria dos povos americanós, principalmente da América Central e do Norte.

Para Sauer (1967), alēm de servir como alimen to básico, os grãos de amaranto foram o material cerimonial 
vegetal mais importante para os Astecas e outros povos mexi canos. Cita que Cortēz, em sua segunda carta ao Rei de Espa nha, durante a conquista, relatou como os astecas faziam seus idolos pagãos com sementes moỉdas e amassadas com sangue de sacrificios humanos. Ele não identifica as sementes, mas existem depoimentos de conquistadores que teriam ficado fascinados com os grandes templos e os bārbaros rituais mexicanos e identificam as sementes de amaranto como usadas na confecção destes ídolos.

Um destes relatos, por exemplo, descreve 0 maior festival anual em honra ao deus da guerra HUITZ LIPOCHTLI, envolvendo danças, possessões e dezenas de vidas huma nas sacrificadas. 0 ponio central da cerimónia consistia de um grande idolo do deus, feito com sementes amassadas de amaranto dentre outras, e dentro deste idolo, estava o san.. gue das vitimas sacrificadas, tambëm misturado com sementes. Este idolo era carregado por toda a cidade e na praça central era quebrado e consumido pelas pessoas participantes (Sauer, 1967).

os espanhōis, juigando este ato como uma parō dia pagã da comunhão catōlica, quando subjugaram os Astecas em 1519, baniram sua religião e com ela, o cultivo do amaranto (Marx, 1977).

Por outro lado, a proximidade dos conquistado res possibilitou a introdução de novas culturas, que ajudaram a diminuir pouco a pouco a importância que os grãos de amaranto possuiam para estes povos. Mas, vestigios deste gru po de plantas tem persistido nos dias atuais, entre remotos grupos indígenas do oeste da terra Mãe e 0axaca e também a guns povoados próximos à Cidade do México (Sauer, 19.67).

Enquanto decaía sua importância para os povos americanos, o amaranto aumentava sua importância na Asia, 
como o caso do Amaranthus hypochondriacus. Existem evidências de espécies encontradas na India e no Ceilão durante o século XVIII. Em meados do século XIX estas piantas se dispersaram para o Himalaia. No final do século XIX propagaram - se para a china e o leste da Sibëria. Atualmente tem aumen tado sua importância na India, principaimente nas regiões montanhosas, onde pode ser cultivado até a $2.600 m$ de altura.

No leste da Africa, os grãos de amaranto foram introduzidos mas não conseguiram se estabelecer. Na Europa, as formas ornamentais assumiram importância no periodo colonial, sendo que as sementes eram tipicamente selva gens, de coloração escura. Entretanto, recentemente, foi descoberto em um herbārio alemão plantas do sëculo XVI, que apresentravam sementes claras de $\underline{A}$. hypochondriacus. Evidentemente estas sementes foram levadas à Europa, mas não conseguiram persistir em competiçäo com os grupos selvagens $j \bar{a}$ existentes.

As espēcies de Amaranthus apresentam cicio C4 de fotossintese, sendo que o maior produto fotossintetico inicial ē o àcido aspārtico. Este ē tambëm, o. chave intermediāria da etapa biossintētica que leva à formação de lisina, um aminoācido essencial limitado em muitos cereais. Anälise dos aminoácidos contidos em sementes de A. edulis revelaram conteūdo em lisina 23 a $30 \%$ maior que no milho opaco-2. A quantidade de lisina errcontrada em A. edulis $\bar{e}$ aproximada mente a mesma que apresenta a carne de soja (Downton, 1973).

Por outro lado, o aminoácido essencial limitante nos grãos de amaranto è a leucina, que se apresenta como o aminoācido que apar̉ece em maiores quantidades em ou tros cereais, principalmente o milho. Esta caracteristica possibilita a utilização dos grãos de amaranto em complemen tação protéica com estes outros cereais. 
Grubben (1976) enfatiza o valor do amaranto produtor de folhas como uma excelente fonte de vitaminas A e C. Altos nîveis de oxalato e nitrato são algumas limitações para seu uso como hortaliça, mas alguns estudos têm mostrado que o consumo de loog ou menos por dia não causa problemas dietéticos (Hauptri e Jain, 1980).

\subsection{Aspectos do crescimento vegetativo e reprodutivo}

Bradshaw et al(1964) foram os primeiros a des tacar a importância ecológica de diferentes taxas de cresci mento. Utilizando-se das gramineas Nardus stricta e Festuca ovina, originärias de solos infërteis, constataram que es " tas apresentavam taxas de crescimento mais baixas do que gramineas provenientes de solos férteis. Foi sugerido que es te crescimento mais lento poderia significar uma vantagem seletiva, como se elas não pudessem ultrapassar o suprimento nutricional disponivel.

Utilizando-se de plântulas de Eucalyptus par sons (1968) obteve lentas taxas de crescimento em populacõos provenientes de solos com pouca capacidade de armazenamento de àgua quando comparado com plàntulas provenientes de solos com grande capacidade de armazenamento de àgua.

Por outro lado, existe uma relação entre baixas taxas de crescimento, susceptibilidade à seca e fertili dade do solo. No mesmo trabalho citado anteriormente, Parsons (1968) encontrou para as 3 espécies de Eucalyptus, aumentos nas taxas de crescimento com o aumento da fertilidade do solo. Constatou também uma correlação positiva entre fertilidade do solo e susceptibilidade à seca.

A maior sobrevivência de plântulas tolerantes à sombra, em baixas intensidades de luz, estaria correlacio 
nada a baixas taxas de crescimento. Grime e Jeffrey (1965), sugerem que a adaptaçăo à sombra envolve seleção para baixa respiração e baixas taxas metabölicas.

Para Evans (1972) ocorre uma substancial dimi nuição na taxa respiratōria por unidade de matéria seca em plantas que crescem em baixas intensidades de luz. Para ele, embora mais observações sejam necessärias, se esta redução na taxa respiratōria puder ser demonstrada como sendo conse quência do sombreamento, seria um importante mecanismo componente do sucesso das plantas de sombra, suplementando nes ta operação as consequências do amplo aumento na ärea foliar especifica em plantas de sombra facultativas.

Este caso apresenta-se particularmente importante quando espécies diferentes participam da mesma estrutura po. pulacional e ocupam estratos diferentes, sendo que una $\vec{e}$ adaptada a condições de sombra e a outra, não. Esta relação torna dificil indicar as causas reais que estariam condicio nando esta adaptaçäo, principalmente no que se refere aos fatores internos.

Ná discussão se estas taxas de crescimento se riam adaptações ao ambiente, faz-se necessärio ter-se em mente a grande diversidade de outras adaptaçŏes para baixos niveis de recursos do ambiente. Por exemplo, eni comparações interespecificas, diferentes mecanismos de controle de transpiração poderiam complicar as relações entre taxa de crescimento e susceptibilidade à seca. Entretanto, parece claro que a seleção de plantas pelo ambiente, com baixas taxas de crescimento e frequente e uma forma simples de adaptação a níveis limitantes de fatores ambientais (Parsons, 1968 ).

Em comparações da fisiologia do crescimento em plantas, pode ser esperado que diferenças determinadas 
geneticamente serão exibidas em circunstâncias ótimas de produção de matéria seca, sendo que a experimentação em con dições de laboratório pode oferecer resultados que avaliem - comportamento das plantas em condições naturais (Grime e Hunt, 1969l.

No que se refere ao crescimento populacional, Harper (1977) destaca que a curva de crescimento da população como um todo pode ser dividida em 3 fases. A primeira delas se caracteriza por um crescimento exponencial, sendo o crescimento populacional função do nümero de sementes pre sentes. Na fase 2, a taxa de crescimento declina e começam a se manifestar os efeitos dos recursos limitados do ambien te. Nesta etapa, o crescimento populacional é determinado pelo espaço e recursos disponīveis, não mais pelo capital investido em sementes: Uma hierarquia se estabelece onde existe uma região onde se situam plantas com crescimento mais lento e outra região em que ocorre predomināncia de plantas com crescimento mais rāpido. As diferenças individuais dentro de uma mesma espēcie e entre espēcies assume um valor alto para a sobrevivëncia da população. E, justamente nesta fase, evidencia-se a importāncia ecológica das diferentes taxas de crescimento.

Jā na fase 3 , a população atinge um estado aproximadamente estāvel, onde começa a existir Equilíbrio po pulacional através da morte de plantas velhas.

\subsection{Fracionamento de energia}

Durante o tempo de vida de uma planta, os pro dutos assimilados são alocados para uma variedade de fins: novos orgãos de assimilação, estruturas de suporte e estruturas de reprodução (Harper, 1977).

Através de evidências de que existiam diferen 
ças neste padrão de alocação de recursos, McArthur e Wilson (1967) desenvolveram a teoria de seleção - $r$ e seleção - $k$. Esta teoria pressupõe que genötipos que älocam granides porções de seus recursos para atividades reprodutivas (estrategistas - r) são favorecidos em ambientes com mortalidade indepen dente da densidade, enquanto genōtipos que alocam baixa fra ção de seus recursos para reprodução em favor de um maior crescimento vegetativo (estrategistas - k) são favorecidos em ambientes onde a mortalidade é dependente da densidade (Gadgil e Solbrig, 1972).

Este conceito foi ampliado por Pianka (1970), para quem existe um continuo de seleção - $r$ e seieção - $k$, onde o ponto final representa o quantitativo extremo, um vāa cuo ecoiógico perfeito, com nenhum efeito da densidade e ne nhuma competição. Nestas condições, a estrąēgia é alocar tanta energia quanto possivel para reproduçäo. o outro ponto final k representa um extremo qualitativo, o efeito de densidade é máximo e o ambiente está saturado de organismos. Neste caso, a estratégia é alocar toda energia possîvel na manutenção e na produção de poucos descendentes (a seleção - k implica num aumento da eficiēncia na utilização dos recursos do ambiente).

Entretanto, para Green (1980), a idéia de seleção - k descrita por McArthur e Wilson (1967), é incomple ta, sem considerar-se a competição entre diferentes fenōtipos.

Os conceitos de estratēgia $r$ e $k$ não são abso lutos e sim relativos, mas de uma maneira geral os genótipos $r$ apresentam um maior número de descendentes, maturidade se xuai precoce e um ciclo de vida curto (Pianka, 1970; Gadgil e Solbrig, 1972). 
A fração de energia que uma espēcie destina à reprodução pode variar com fatores genéticos e ambientais (Gadgil e Solbrig, 1972; Abrahamson e Gadgi1, 1973, Abraham son, 1979).

Os conceitos de seleção - $r$ e seleção - $k$ relacionam-se aos efeitos da mortalidade dependente e indepen dente da densidade. Uma vez que os efeitos da mortalidade independente da densidade diminuam com o amadurecimento da comunidade, os individuos desta irão progressivamente alocar menos recursos a atividades reprodutivas (Abrahamson e Gadgil, 1973).

A distribuição da biomassa entre os vārios or gãos vegetativos das plantas deve depender, em grande.parte, da natureza dos recursos limitantes como nutrientes, água, luz, etc. Abrahamson e Gadgil (1973) argumentaram que, se a luz for um fator limitante, então a forma de crescimento do competidor dominante pela luz será importante na determinação se a planta irä responder

(1) alocando mais biomassa para ramos, o que resultará em plantas altas que evitam sombreamento, ou

(2) alocando mais biomassa para folhas, o que resultarā em plantas que interceptam mais a luz disponivel.

Consequentemente, é previsĩvel que a proporção biomassa de folhas/total de biomassa irá aumentar en po pulações limitadas de luz como a forma de crescimento dos competidores aumenta igualmente para maior estatura. Este padrão de alocação foi encontrado por Abrahamson (1979) e Gaines et al (1974).

Afirmar que ambientes estāveis favorecem indi viduos com altas taxas de reprodução, enquanto ambientes 
constantes favorecem indivíduos com alta longevidade năo se caracteriza como regra gerä. A idade com que as flutuações afetam os organismos merece consideraçôes prioritärias (schaffer, 1974).

Tambëm merece questionamento o fato do concej to de seleção $r$ e $k$ pressupor que todas as sementes produzi das por uma planta contribuiram igualmente para a adaptabilidade desta. Na prätica, as sementes produzidas em diferen tes estágios da planta são diferentes em nümero e fisiolo. gia. Por esta razão, as capacidades reprodutivas deveriam ser comparadas com tabelas de tempo (Harper, 1977).

0 tamanho das sementes é um caracter hereditä rio bastante afetado pela seleção natural. Werner e platt, citados por Harper (1977) utilizando-se de seis especites de Solidago, provenientes de estados sucessionajs antigos e re centes, constataram que o nümero e o tamanho das sementes 2 presentavam correlações negativas em habitats diferentes.

Estes dados ilustram que o numero de sementes e o tamanino destas parecem ser alternativas na estratégia reprodutiva.

A seleção natural irä determinar a estratēgia que possibilite um máximo individual de adaptabilidade e re flita o compromisso entre diferentes pressões de seleção.En tretanto, o fato de componentes desta estratëgia poderem ser correlacionados com parāmetros ambientais não demonstra que estes parâmetros tenham sido responsāveis pela evolução des tes caracteres. Para Harper (1977), as diferenças na capacidade reprodutiva das plantas representam diferentes compromis s.os adaptativos. A seleçäo natural age de forma : a otimizar estes compromissos e maximizar a* adaptabilidade individual.

o esforço reprodutivo de um organismo ē me- 
Thor estimado através da fração total de energia medida em calorias (Harper e Ogden, 1970). Contudo, alguns trabalhos tëm demonstrado que a utilização do peso seco da biomassa para os diversos orgáos mostra-se eficiente quando comparado ao método colorimétrico. Soares (1930) utilizando-se de populações de Stylosanthes guianensis concluiu que, para efeitos comparativos de distribuição fracionäria de energia, entre populações aparentadas, não se faz necessärio a deter minação colorimétrica do material. As comparações podem ser feitas utilizando-se apenas o peso seco da biomassa. Entretanto, o método colorimētrico sō seria aconselhável para as espécies que armazenassem altos teores de lipídeos.

Harper e Ogden (1970) chamaram a atenção para o fato de se incluirem -utras estruturas alem das sementes, como esforço reprodutivo. Segundo estes autores, quando estas estruturas não são muito deigadas, super estiman o esforço reprodutivo. Contudo, as estruturas do ovärio e de dispersão, constituem um custo para reprodução e assim, parece lógico inclui-las como parte do esforço reprodutivo. (Barriga, 1979).

De um modo geral, os trabalhos sobre estratēgias reprodutivas têm sido dirigidos no sentido de comparar plantas alluais e perenes, precoces e tardias, selvagens e cultivadas, em suas diferenciações de alocação de recursos (Harper e Oyden, 1970; Ogden, 1974; Pitelka, 1974; Hauptii e Jain, 1978), ou então, como o habitat natural das espécies influencia na sua estratēgia (Gadgil e Solbrig, 1972 ; Abrahamson e Gadgi1, 1973; Gaines et al, 1974, Hickman e Pi telka, 1975 e Abrahamson, 1979). Atualmente, vem sendo desenvolvidos trabalhos para se determinar a variação intrâ-especiffica com relação äs estratēgias reprodutivas, enfatizando a varia bilidade existente entre diferentes populações de uma mesma 
espēcie (Soares, 1980; Barriga, 1979).

2.5. Caracterização da competição intraespecïfica

A presença de uma pianta pode mudar o ambiente de sua vizinhança e alterar sua forma e taxa de crescimento. A este efeito Harper (1961) denominou de interferência. Plantas superiores reagem ao stress de densidade atravës de respostas plásticas, tanto como alterando o risco de morte. Como citado anteriormente, também podem ocorrer variações nas taxas de nascimento e morte de suas partes, co mo ramos, folhas, raizes, etc.

Muitos dos estudos experimentais das reações das plantas a condiçóes de stress foram feitos por agrōno mos e engenheiros florestais, no sentido de determinar densidades de plantio vantajosas economicamente (Harper, 1977 ).

Donald (1951) utilizando-se de duas espécies, Trifolium subterraneum e Lolium ioliaceum, em diferentes densidades, observou que no inicio do ciclo vegetativo a re lação produtividade/biomassa foi linear. Com o decorrer do tempo esta linearidade desapareceu e a produtividade por unidade de ārea tornou-se independente do nümero de sementes semeadas numa ampla faixa de densidades. .

Como este fato foi observado em uma sērie de plantas, foi denominado Lei da Produtividade Final Constante (Kira et al, 1953; Harper, 1977).

Este plató de produtividade final $\bar{e}$ determina do pelos recursos, que são limitados no ambiente. Donald (1951) semeando Bromus unioloides em diferentes densidades e diferentes niveis de fertilizações com nitrogēnio, consta tou que a Lei da Produtividade Final constante se manifesta mas o plató de produtividade final ē maior nos maiores ní- 
veis de fertilizações nitrogenadas.

Entretanto, conforme se aumenta a densidade, a proporção de alocação de produtos assimilados para os diferentes orgãos da planta se altera. Existem indicações de que a produção final de sementes modifica-se nesta realocação (Harper: 1961).

Um problema com o qual se depara no estudo da produtividade/densidade de plantas é a maneira como trabaThar com os dados. Kira et al (1953) sugeriram utilizar-se da anālise gráfica do logaritmo do peso seco total das plantas/densidade. O gräfico, neste caso, caracteriza-sépor uma linha horizontal que se torna inclinada na medida em que a interferencia entre as plantas se manifesta. A inclinação varia de 0 e se aproxima do valor 7 quando a produtividade torna-se independente da densidade (produtividade fi nal constante).

A dificuidade desta metodologia de anālise consiste na necessidade da utilização de duas linhas de regressã̃o numa sequência continua de densidades, sendo que a relação entre elas não passa de uma forma de apresentação (Harper, 1977).

Posteriormente, Shinozaki é Kira (1956) propu zeram a existência de uma relação linear entre o peso médio das plantas/densidade. Esta linearidade (Lei da Produtivida de Recīprocal estā atualmente determinada para uma sērie de plantas (Holliday, 1960), sendo que a equação $1 / w=A d+B$, on de $w$ = peso médio das plantas e $d=$ derisidade, pode ser usada para determinar a curva do gräfico logaritmico do peso médio $\log$ da densidade de plantas. Entretanto, existem crí.ticas no sentido de que as plantas pequenas das altas densi dades comprometerem a anālise de regressão (Harper, 1977). 
Quando as plantas são medidas individualmente, encontra-se uma distribuição desuniforne dos pesos. Esta de suniformidade aumenta com o tempo e a densidade, estabelecendo-se uma hierarquia com a presença de uma grande maioria de individuos "pequenos" e "fracos" e uma minoria de in divỉduos "fortes" (quando em altas densidades).

Obeid, Machin e Harper (1967). encontraram em Linum usitatissimum uma frequência normai de distribuição lo garítmica da matéria seca, quando relacionada ao tempo e $\bar{a}$ densidade. 0 nūmero de cāpsulas por planta mostrou uma distribuição assimétrica, enquanto o peso mēdio e individual de sementes por cäpsula manifestou-se menos sensivel a diferen ças de densidade e tambëm uma frequéncia de distribuição as simétrica. Os autores concluem que è bastante suspeito, em estudo de populações de plantas, usarem-se de recursos arit méticos e de variância para fins comparativos, uma vez que os dados obtidos em seu trabalho não apresentavam atributos de uma distribuição normal.

Com relação à altura de plantas em diferentes densidades, encontra-se um comportamento relativamente normal ou em relação assimētrica negativa ä freqléncia de pesos em plantas anuais (Koyama e Kira, 1956; Harper, 1977).

Em stands naturais de Elastostema rugosum, a distribuição de pesos e alturas de plantas sugere que os in divíduos de peso baixo em populações densas, tendem a manter sua altura na posição abaixo do dossel criado pelas pou cas plantas grandes (Ogden, 1970; Harper, 1977).

o lugar que o indivíduo ocupa na hierarquia da população parece ser determinado nos estägios iniciais de seu desenvolvimento e se apresenta em função dos seguintes parâmetros propostos por Harper (1977): 
(1) capitai inicial (peso do embrião + algumas frações do endospermal;

(2) taxa reilativa do crescimento, caracteristico do genótipo do indivìduo e das condições ambientais;

(3) o espaço de tempo no qual o crescimento se processa,

(4) restrições ao crescimento imposto pela pre sença, caracterīsticas e arranjamento da vizinfıança na popu1 ação.

Com relação à mortalidade, existem duas catego rias: mortalidade dependente da densidade e mortalidade inde pendente da densidade. O termo "self-thinning" tem sido usado quando a mortalidade apresenta-se em decorrēncia da dens dade na população (Harper, 1961; Yoda et al, 1963) em contraste com "allien-thinning" que se refere ao stress de densidade de uma outra espécie como responsävel peia mortali dade (Harper, 1977).

Em Agrostema githago. (L) a mortalidade

en stands puros apresentou-se independente da densidade, embora manifestações plásticas relativas a partes da planta fossem observadas. Por outro lado, quando semeada com outras espëcies, Beta vulgaris ou Triticum sativum, a mortalidade de Agrostema githago manifestou-se bastante dependente da densidade (Harper e Gadgil, 1961).

Em stands florestais, observou-se um aumento da mortalidade dependente da densidade com o aumento da fertilidade do solo, devido a um aumento do vigor e consequente taxas maiores no crescimento dos sobreviventes, levando a uma maior taxa de mortalidade (Sukatschev, 1928; Harper e Gadgil, 1961 ). 
A severidade do "self-thinning" $\bar{e}$ bastante afetada por condições ambicntais e apresenta-se associada a atividades patogenicas (Gibson, 1956; Hiroi e Monsi, 1966; Harper, 1977l.

o nümero de estudos relativos ä mortalidade densidade de plantas é bastante pequeno, sugerindo que o ris co de mortalidade é alto durante a fase de plântulas e vai se tornando constante durante o ciclo de vida. 0 processo de "self-thinning" envoive mudanças nas taxas de assimila ção de energia pelos individuos e as plantas que morrem são aquelas com taxas assimilatorias negativas ou baixas (Har.per, 1977).

\subsection{Caracterização da competição interespecificica}

0 arranjamento espacial dos individuos em relação à vizinhança torna. se ainda mais importante quardo se considera a entrada de poucos individuos de uma nova especie em uma dada população. A principio, enquanto a nova espécie é rara seräo estabelecidos principalmente contatos in terespecificos; na verdade, todos os contatos feitos peio primeiro "invasor" individual serão interespecificos. Se a espēcie nova tem sucesso e se muitiplica, a frequéncia dos contatos intraespecificos aumenta e a chance do novo "invasor" estabelecer contatos interespecificos declinam (Harper, 1977).

Com o desenvolvimento do ciclo vital nas plan tas, as relaçöes de vizinhança, a distância entre os indivi duos e o tempo no qual eles se estabeleceram são rariäveis dificeis de serem analisadas experimentalmente. Alguns mode los foram propostos no sentido de se obter metodologia de estudo apropriada para esta ärea do conhecimento.

0 experimento aditivo (ciements et al, 1924 - 
$a, b)$ consiste de duas espécies crescendo juntas e sendo que a densidade de uma é mantida constante enquanto a outra se apresenta variāvel. A espécie que permanece constante age como um indicador comparativo da agressividade a outra espëcie testada.

Muitos experimentos do tipo aditivo têm sido feitos para medir o efeito das ervas daninhas na produtividade de plantas cultivadas. Infestações experimentais em tri go, como por exemplo, Alopecurus myosuroides em densidades de 30,100 e $300 \mathrm{plantas} / \mathrm{m}^{2}$ acarretaram reduções em 12, 32 , $36 \%$ na produção da cultura de trigo (Naylor, 1972: Harper, 19.77).

Em experimentos de substituição (Wit, 1960), a proporção de cada uma das espécies varia enquanto a proporção total das duas espëcies permanece constante. Neste caso espera-se encontrar dois tipos de respostas em plantas: o primeiro consiste na equiva]éricia do comportamento das duas espēcies em mistura, tendo como consequéncia a demanda de frações semelhantes de recursos do ambiente, possibilitando prever-se atraves de stands puros, o comportamento das espēcies em mistura (Harper, 1977). Num segundo caso, as duas espécies demandam os mesmos recursos do ambiente mas, uma delas se apresenta menos eficiente na captura destes re cursos.

Para o primeiro tipo de respostas, onde existe a possibilidade de se prever, através de stands puros, o comportamento da espécie em mistura, a agressividade de uma espécie sobre a outra pode ser medida a partir do coeficien te coletivo relativo. Este estabelece uma relação de equiva lēncia entre as produtividades mēdias por planta, das espëcies testadas em mistura e em stands puros.

Nos casos em que näo ê possîvel prever-se o 
comportamento das espëcies em mistura a partir dos stands puros, utiliza-se um outro coeficiente, denominado Produtividade Relativa. Neste caso, a relaçäo se estabeiece atravēs do quociente da produtividade da espécie na mistura e a produtividade da mesma espécie em stands puros.

0 estudo de algumas espécies, sob diversas condições ambientais, demonstrou que a produtividade da mis tura comumente excede levemente a produtividade média dos stands puros. Entretanto, o cultivo em vasos quase certamen te força a espécie a usar o mesmo espaço e recursos do solo, enquanto no campo, diferentes espécies podem penetrar dife-rentes zonas com suas raizes e escapar, de alguma forma, do stress interespecifico (Harper, 1977).

0 uso direto da anālise da variancia foi encontrado em estudos de Sakai (1955), Wilitaris (1962) \& de uma maneira mais sofisticada (McGilchrist, 1965; McGiichrist e Trenbath, 1971). Em trabalhos mais recentes introduziumse o conceito de Produtividade Total Relativa (PTR), no qua? se consideram as mudanças proporcionais que ocorrem na mistura (Harper, 1977).

A produtividade total relativa (PTR) e calculada atraves das produtividades relativas obtidas para as duas espécies e a soma dos dois valores permite o cālculo do. PrR, que, por sua vez, irā descrever as relações mūtuas do par de espécies no que se refere à demanda de recursos do ambiente.

Valor de PTR $=1,0$ implica que as duas espe cies estão demandando os miesmos recursos limitados do ambiente. Quando PTR $>1,0$, sugere que as espēcies demandam re cursos diferentes do ambiente, evitando competição entre elas e mostrando alguma forma de relação simbiōtica (pelo me nos no que se refere à produtividade combinada). Valores de 
PTR $<i, 0$ implicam em antagonismo mūtuo (Harper, 1977)

Utilizando-se Panicum maximum e Glycine javanica, Wit et al (1966), testaram, atravēs de experimentação do tipo Séries Repassadas (experimentos substitutivos) o comportamento destas espécies diante de diferentes tratamen tos com adubação nitrogenada, sem adubação e inoculação com Rhizobium. Os dados foram analisados através de valores da produtividade relativa total (PTR) e indicaram que, sem a $\underline{i}$ noculação ou fertilizações, observam-se valores de $P T R<1,0$ existindo um ligeiro aniagonismo entre as espécies. Nos vasos em que se procedeu a fertilizações nitrogenadas, as espécies comportaram-se em relação competitiva simples, compe tindo pelo mesmo espaço. A inoculação com Rhizobium determi nou valores de PTR $>1,0$, indicando que elas não mais demandam dos mesmos recursos limitados; provavelmente a espēcie Glycine javanica, por ser uma planta leguminosa, torna-se independerite do suprimento de nitrogênio do solo, receben do-o de süa associação simbiótica com o Rhizobium. No caso em que Glycine foi inoculada e são adicionadas fertilizações nitrogenadas, os valores de PTR são maiores que 1,0 , mas os efeitos sã̃o menos marcantes do que sem fertilizações nitrogenadas.

Em quatro espécies do gēnero Avena, A. strigosa, A. fatua, A. sativa e A. ludoviciana, semeadas em stands puros e em mistura, Trenbath e Harper (1973) encontraram valores de PTR $>1,0$ quando A. faiua e A. strigosa cresceram juritas em solos profundos, mas, em solos rasos,os valores de PTR aproximaram-se de 1,0. Em trabalho posterior

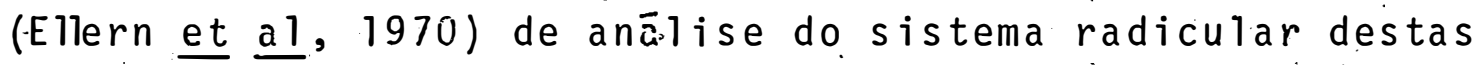
mesmas espēcies, notou que em solos profundos, as raizes de A. strigosa desenvolveram-se mais ativamente nas camadas su periores do perfil do solo, enquanto A. fatua explorou as . camadas profundas do solo com suas raỉzes. 
Estudos referentes a sistemas radiculares são problemäticos devido a dificuldades na utilização de metodo logia apropriada na obtenção de dados; embora pareça lógico que uma compreensão da estrutura dos sistemas radiculares seja um bom caminho na interpretação das relações entre as espécies.

Num outro trabalho utilizando-se do enfoque no sistema radicular e partindo de trabalhos anteriores, que indicavam que, em populaçóes de Plantago lanceolata L. e An thoxanthum odoratum $L$, apresentavam valores de PTR excedendo a unidade, Berendse (1981) delineou os seguintes experimentos.

No primeiro deles foi feita comparação entre uma sērie em que os nutrientes disponĩveis limitavam severa mente o crescimento das plantas e en outra série em que os nutrientes foram aplicados em quantidades que levavam a uma alta produtividade. Nas āreas dos solos pobres, O PTR excedeu a unidade em aproximadamente $20 \%$, enquanto nas sëries ricas em nutrientes, somente um pequeno desvio foi observado. A explicação que o autor oferece para este resultado é que a limitação da produção devido a algum nutriente, nas sēries fertilizadas, poderia explicar este desvio inesperado de 1,0 .

Um segundo experimento visava constatar a con clusão chegada em experimentos anteriores, de que plantas com sistemas radiculares ocupando profundidades diferentes do perfil do solo, apresentavam coeficientes relativos cole tivos diferentes.

o experimento foi dividido em uma sērie de va sos fundos, nos quais os sistemas radiculares das duas espé cies desenvolviam-se livremente, e uma outra série de vasos rasos, nos quais as duas espēcies foram forçadas a habitar o mesmo espaço. 
0 resultado obtido foi que o coeficiente relativo coletivo das duas espécies apresentavam-se independente da frequëncia de plantas na série de vasos rasos, enquanto, nas séries de vasos fundos, o coeficiente relativo coletivo tambēm não decaiu significativamente com o aumento da frequēncia de plantas.

Esta ārea de pesquisa apresenta perspectivas de um desenvolvimento promissor no futuro, embora, na etapa atual, os trabalhos publicados sejam poucos e em busca de formas adequadas de interpretação dos dados obtidos. 
3. MATERIAL E METODO

3.1. Determinação do ciclo vital

3.1.1. Instalação do experimento

Uma vez que são bastante restritos os traba-! Thos relacionados às espēcies do gēnero Amaranthus no Brasil, houve preliminarmente a necessidade de se observar o comportamento das espécies em condições naturais.

Durante o ano de 1982, foram feitas observações e coletas de sementes nos seguintes locais: Fazenda Areião - ESALQ, Piracicaba; Fazenda Experimental de Anhembi, Piracicaba, SP e regiões próximas ao parque da ESALQ-USP. Fo ram observadas as espécies presentes e o possivel padrão, na presença destas espécies, em relação às plantas vizinhas e às condições do solo.

Em janeiro de 1383 foi instalado o primeiro experimento, que constou das seguintes espécies: 
Espécie Procedéncia

A. deflexus L. Campus ESALQ E Fazenda Anhembi

A. hybridus L. Região de Campinas, SP

A. retroflexus L. Região de Campinas, SP

A: spinosus L. Região de Rio Claro, SP

A. viridis L. Região de Campinas, SP

0 plantio procedeu-se no dia 4.1.1983. Foram utilizados para cada espécie, 10 yasos com diàmetro de $30 \mathrm{~cm}$, solo de mata esterilizado e sem adubaçầo quîmica. Foram fei tos dois desbastes. 0 primeiro, uma semana após o plạtio, quando foram deixadas aproximadamente cinco plantas por vaso e o segundo, duas semanas apōs o plantio, quando se deixou apenas uma planta por vaso.

0 verão de 1983 caracterizou-se por um excesso de chuvas, conseqüentemente, foi necessārio tratamento preventivo de doenças com aplicação de Dithane durante. o primeiro més do experimento. Apesar disto, ocorreu em A. de flexus, doença vascular provocada por fungos do gênero Phytium, que dizimou todos os representantes desta espëcie.

3.1.2. Caracterização do crescimento vegetativo e reprodutivo de $A_{\text {. }}$ hybridus, A. retroflexus, A. spinosus e A. viridis

A partir do final do primeiro mês, iniciaramse anotações referentes ao comprimento da haste e do compri mento da inflorescéncia até o finai da fase reprodutiva das plantas, de acordo com metodologia proposta por Hauptli e Jain (1978). Estas medidas foram tomadas em $\mathrm{cm}$, utilizandose escala métrica, a cada quatro dias, no princípio, e no 
final do ciclo, a cada semana.

A partir destes dados, foram determinadas as taxas médias de crescimento da haste e da inflorescencia, a travēs da seguinte fórmula $V_{m}=S / T$, onde $S=$ medida do comprimento em $\mathrm{cm}$, $T=$ tempo medido $\mathrm{em}$ dias e $V \mathrm{~m}=$ taxa mēdia de crescimento.

Os critérios que indicaram o final do ciclo foram: amarelecimento das folhas, parada tanto do crescimen to vegetativo quanto reprodutivo e uma queda abundante de sementes. Nesta fase, foram tomadas medidas do comprimento final da haste principal, inflorescência e raizes, em condi ções de laboratōrio.

\subsubsection{Distribuição fracionāria de energia}

Uma vez a pianta tendo atingido o final do seu ciclo vital, procedeu-se a separação de suas diferentes par tes.

As raizes foram separadas do solo e posterior mente, lavadas. Conforme metodologia citada por Harper (1977) as plantas foram secadas em estufa a $70^{\circ} \mathrm{C}$ por 72 horas. Pro cedeu-se a separação em parte reprodutiva (inflorescências e sementes) e parte vegetativa (folhas, ramos e raĩzes). 0 peso seco foi obtido em halança do tipo Mettier. Foram elaborados cálculos percentuais da alocação de energia.

A anālise dos dados foi executada de duas maneiras: a primeira foi a anālise grāfica das mensurações re ferentes ao comprimento da haste principal e da inflorescēn cia e do peso em gramas das partes vegetativa e reprodutiva.

A segunda se refere à anālise da variäncia se 
gundo delineamento inteiramente casualisados tanto para os dados referentes ao comprimento como para os referentes ao peso.

Como se observou significância nos valores de $F$, a anālise foi completada utilizando-se teste de Tukey (Pi mentel Gomes, 1982). Os valores de $S$ foram de 5 e $1 \%$ de pro babilidade, a fim de se estabelecerem diferenças minimas si gnificativas quanto às características referentes às espe-cies estudadas.

\subsection{Estudo de aspectos da dināmica populacional}

\subsubsection{Instalação do experimento}

Durante as observações de campo, constatou-se que as espécies A. hybridus e $\underline{A}$. defiexus ocupavam áreas co muns, atravēs de um marcante crescimento vertical de $\underline{A}$. hybridus e um crescimento lateral e prostrado de A. deflexus.

Baseando-se numa sërie de trabalhos propostos por Harper (1977), decidiu-se demarcar äreas de ocorrência das duas espécies em questão. Foram tomados quadrados de $1 \mathrm{~m} \times 1 \mathrm{~m}, 2 \mathrm{~m} \times 2 \mathrm{~m}, 3 \mathrm{~m} \times 3 \mathrm{~m}, 4 \mathrm{~m} \times 4 \mathrm{~m}$ e $5 \mathrm{~m} \times 5 \mathrm{~m}$ e foi contado a número de plantas de cada espécie presente nos diferentes quadrados.

Esta metodologia foi desenvolvida a fim de se determinar a capacidade de suporte por $m^{2}$ para cada uma das espécies estudadas. Concomitantemente, foram retiradas cinco plantas de cada uma das espécies e processada a metodolo gia de análise do fracionamento de energia citada anteriormente.

Procedeu-se tambēm, teste de germinação para 
se detectar o vigor das sementes a serem utilizadas nos ensaios de densidade e de competição. Utilizou-se câmara de germinação úmida, temperatura constante de $25^{\circ} \mathrm{C}$ e ausēncia. de 1 uz. Estas condições mostraram-se ideais para germinação de Amaranthus, em ensaio desenvolvido por Bialoskorski e Martins (1981).

3.2.2. Ensaio de densidade para caracterizaçäo da competição intraespecífica

0 objetivo deste ensaio foi testar respostas das plantas de A. hybridus e A. deflexus em 5 condições diferentes de densidade.

Para tanto, utilizaram-se vasos com $3 a \mathrm{~cm}$ de diâmetro, solo esterilizado e sem adubação química. o delineamento experimental foi de blocos inteiramente casualisados e o número de sementes utilizadas em cada tratamento en contra-se no quadro abaixo.

\begin{tabular}{ccccccc}
\hline \multicolumn{5}{c}{ no sementes } \\
\hline Espécie & D1 & D2 & D3 & D4 & D5 \\
\hline A. hybridus & 6 & 12 & 24 & 48 & 96 \\
A. deflexus & 6 & 12 & 24 & 48 & 96 \\
\hline Ao todo foram feitas & 3 repetições para cada
\end{tabular}
tratamento e obtido o peso em gramas da parte vegetativa (ra mos + folhas + raizes) e parte reprodutiva (inflorescēncias + sementes). Com estes dados, confeccionaram-se gráficos que indicam a tendência do comportamento das espēcies sob pressão de competição de densidades crescentes nas condições ex perimentais de vaso. Estes grāficos representam o comportamento médio das espēcies. 
3.2.3. Ensaio de competição para caracterizar a competição interespecîfica

Numa ūltima etapa, precedeu-se ensaio onde as duas espécies, A. hybridus e A. deflexus, foram semeadas em diferentes proporções no mesmo vaso.

0 esquema experimental foi baseado em modelo experimental substitutivo proposto por de Wit (1960) e se constituiu das seguintes proporções de sementes para cada ES pëcie:

\begin{tabular}{lcc}
\hline & A. hybridus & A. deflexus \\
\hline nọ de & 0 & 100 \\
semen & 25 & 75 \\
tes & 50 & 50 \\
& 75 & 25 \\
& 100 & 0 \\
\hline
\end{tabular}

Foram feitas 3 repetições para cada tratamento, num total de 15 vasos, obtido o peso em grama da alocação de energia para atividades vegetativas (ramos + folhas) e reprodutivas (inflorescēncia + sementes), ao final do ciclo vital.

Como metodologia de anālise foram calculadas as produtiviades relativas de A. hybridus e A. deflexus, a partir da seguinte fórmula (Harper, 1977):

$$
R I=\frac{\bar{x} I}{\bar{y} I} " \text { onde }
$$


RI = produtividade relativa da espécie $I$

$\bar{x} I$ = produtividade da espécie I na mistura

$\bar{y} I$ = produtividade da espécie I em stands puros

A produtividade total relativa (PTR) foi calculada através da soma das produtividades relativas referen tes a cada espécie.

Tanto nos ensaios de competição intraespeç̄fica como nos de competição interespecífica, a luz solar in cidente foi a mesma para todas as repetições, tendo sido to mados cuidados no sentido de não haver sombreamentos. 
4. RESULTADOS E DISCUSSÃO

4.1. Determinação do ciclo vital

4.1.1. Caracterização do crescimento vegetativo e reprodutivo de A. hybridus, A. retrofiexus, A. spinosus. e A. viridis.

Evidências citadas em literatura comprovam a importancia ecolögica de diferentes taxas de crescimento na dinämica da estrutura populacional (Bradshaw et al, 1964; Parsons, 1968; Harper, 1977).

os dados obtidos na fase de crescimento encon tram-se nas tabelas 1 e 2 e os gräficos $1,2,3,4,5$ e 6 , que foram confeccionados a partir destes dados, permitem-nos as seguintes considerações:

- as maiores taxas médias de crescimento da haste principal foram apresentadas em ordem decrescente por A. hybridus, A. retroflexus, A. spinosus e A. viridis (tabe 1.a 2, gräfico 1). Quando se observa a arquitetura das plantas, pode-se constatar a ausēncia de ramificações laterais em A. hybridus, enquanto A. retroflexus apresenta ramificações desde a base e A. spinosus e A. viridis um häbito de crescimento sem dominância apical, caracterizado por um a- 
centuado desenvolvimento lateral. Uma vez que as medidas das taxas de crescimento da haste e da inflorescência foram tomadas a partir do eixo principal, os resultados obtidos per mitem estabelecer paralelo entre arquitetura das plantas e taxas de crescimento da haste principal.

No que se refere às taxas mëdias de crescimen to da inflorescéncia, foi encontrada a seguinte ordem decrescente: A. retrofiexus, A. hybridus, A. spinosus \& A. vi ridis (tabela 2, grä́fico 2). Ocorre domināncia apical no crescimento da inflorescēncía em A. retroflexus e A. hybridus, sendo pouco desenvolvidas as inflorescencias iaterais das extremidades da ramificação de R. retrofiexus e as inflorescencias que se estabelecem nas axilas das folhas supe riores de A. hybridus. Já en A. spinosus, as inflorescéncias presentes nas extremidades das ramificaçöes apresentam um desenvolvimento acentuado, o mesmo ocorrendo com A. viridis, embora em proporçöes inferiores.

Apesar de näo haver sido feita uma descrição criteriosa, observou-se a presença de populações naturais das quais faziam parte as quatro espëcies presentes neste trabalho experimental. Evidencia-se consequentemente, a importância ecológica do paralelo entre arquitetura de planta e taxas de crescimento, uma vez que estas diferenças possibilitam a exploração de diferentes arranjamentos espaciais pelas diferentes espēcies.

Para Harper (1977), no crescimento populacional de plantas, após um certo tempo, se estabelece uma hierarquia onde se situam, numa determinada região, plantas com crescimento mais lento e em outra região, ocorre predominân cia de plantas com crescimento mais rápido. Destaca que diferenças individuais de uma mesma espēcie e entre espécies, assumem um valor alto para a sobrevivencia da população. 
Visando estabelecer uma relação entre taxas de crescimento vegetativo e reprodutivo, constatou-se em A. hybridus que as altas taxas de crescimento da haste prin cipal coincidiram com as maiores taxas de crescimento da in florescēncia (tabela 2, gráfico 3), sendo que, apōs esta fa se, ocorreu uma queda acentuada no crescimento tanto da inflorescência como da haste principal. Provavelmente, nesta fase, a planta esteja alocando sua energia para a maturação das sementes.

Já o A. retrofiexus (tabela 2, gräfico 4) caracteriza-se por apresentar altas taxas de crescimento da haste principal antes da planta entrar em fase reprodutiva (V4). No inicio da fase reprodutiva, observa-se uma diminuição do crescimento vegetativo ( $\vee 5-V \delta)$, embora próximo ao final do ciclo (V7) a planta retome o crescimento da haste principal. Aos 80 dias do ciclo (V8), . . retroflexus não mais apresenta crescimento da haste principal nem da inflorescência, devendo estar alocando sua energia para maturàção das sementes.

Em relação a A. spinosus (tabela 2, gräfico 5) ocorre um aumento constante das taxas de crescimento da has te principal durante o ciclo vital, sofrendo uma queda abrup ta ao final dos 80 dias. Já as velocidades de crescimento da inflorescência apresentam uma constância, sencio que, quando a ūitima medida foi tomada, a planta ainda apresenta va crescimento da inflorescência. Esta seria uma indicação de que o ciclo não havia chegado ao seu final quando o expe rimento foi encerrado.

A espēcie com menores taxas de crescimento tan to da haste como da inflorescência, foi o A. viridis (tabela 2, gräfico 6) sendo que o término de seu ciclo ocorreu a proximadamente 60 dias apōs o plantio. As observações de 
campo, nesta época, indicavam o encarquilhamento da planta como um todo e uma queda abundante das sementes.

No que se refere ao ciclo vital, as seguintes generalizações são possîveis:

- A. viridis è a espēcie mais precoce, comple tando seu ciclo em 60 dias;

- A. hybridus e A. retroflexus apresentam ciclo de 80 a 90 dias,

- A. spinosus completa seu ciclo em tempo maior que 90 dias. 


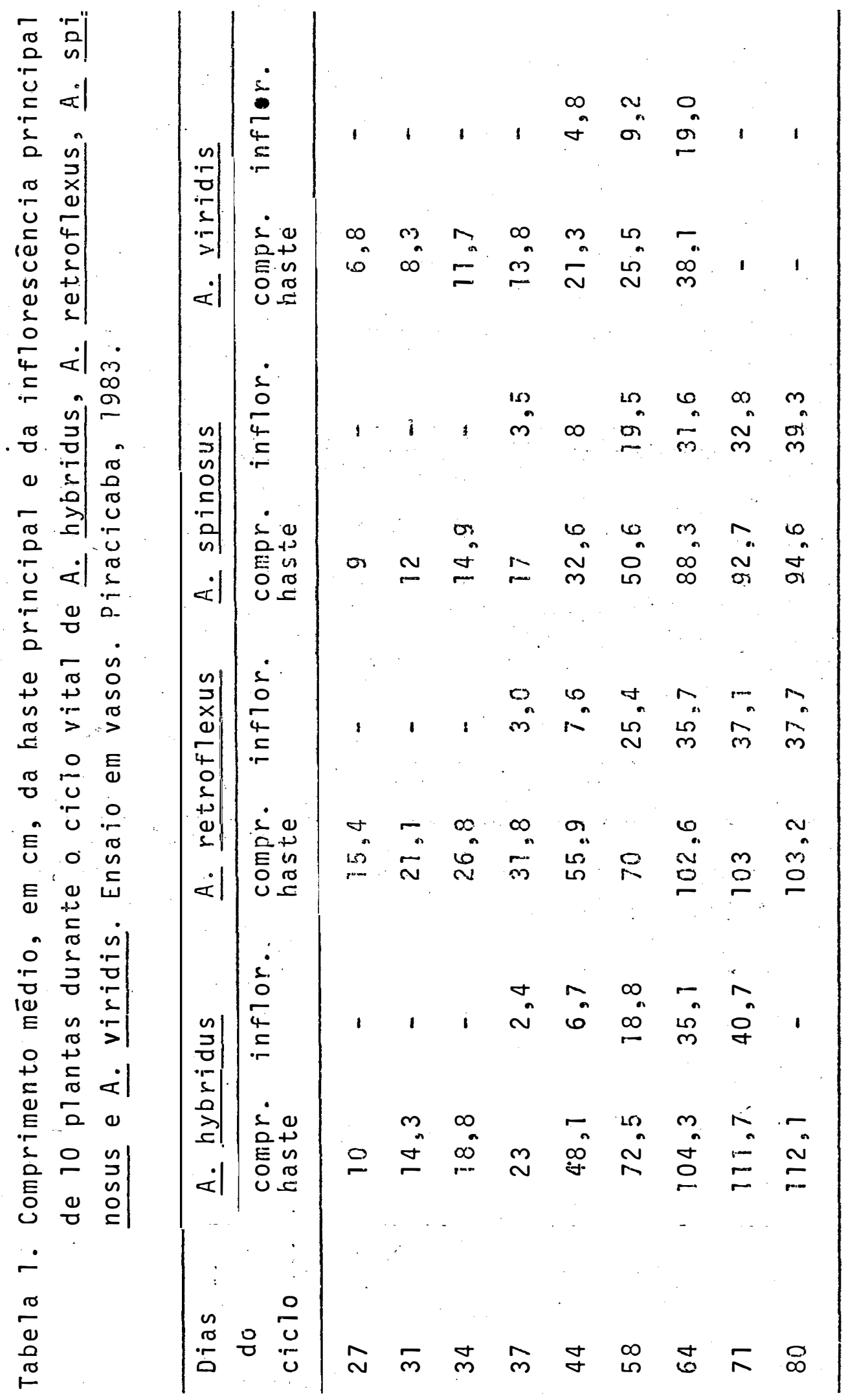




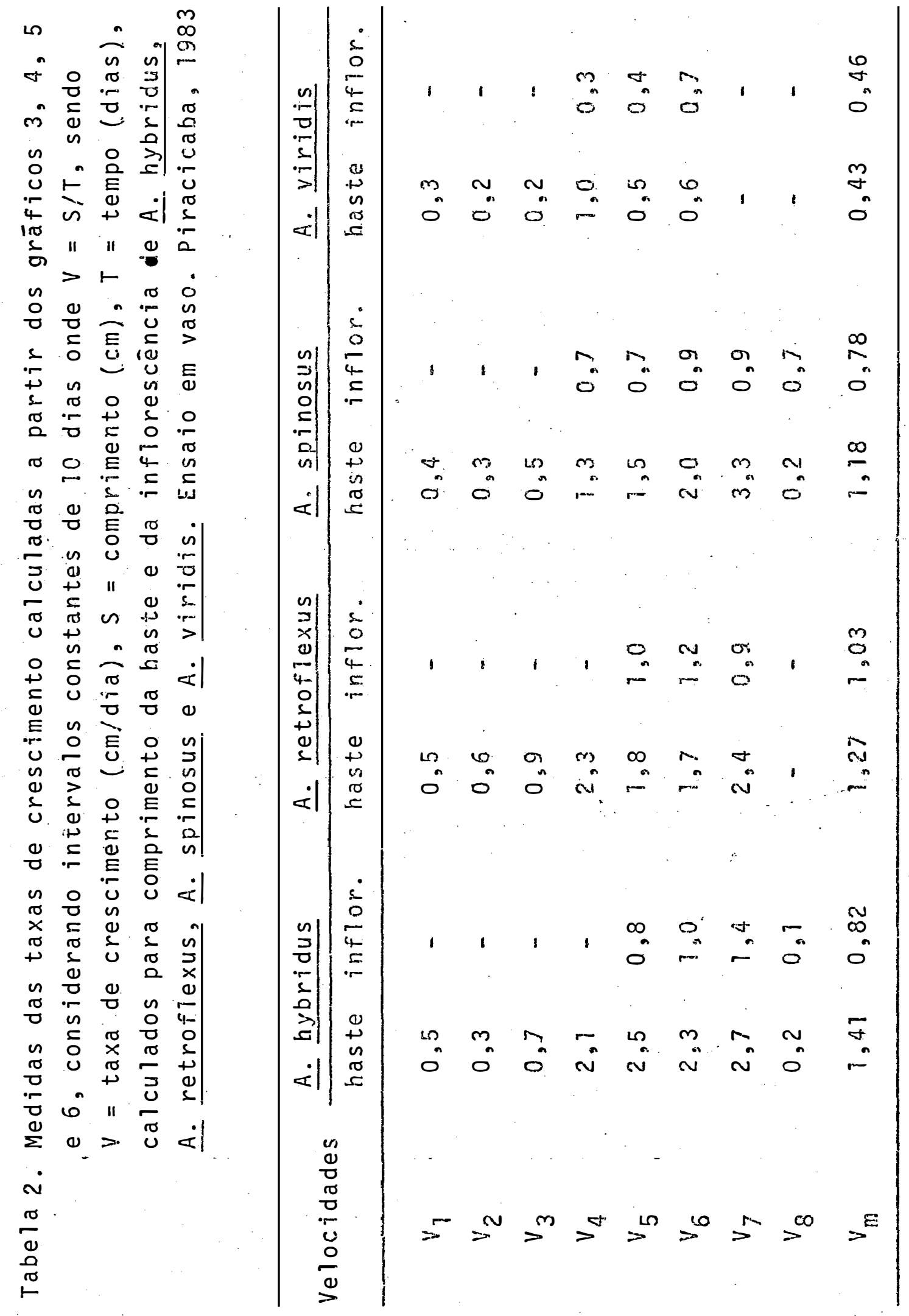




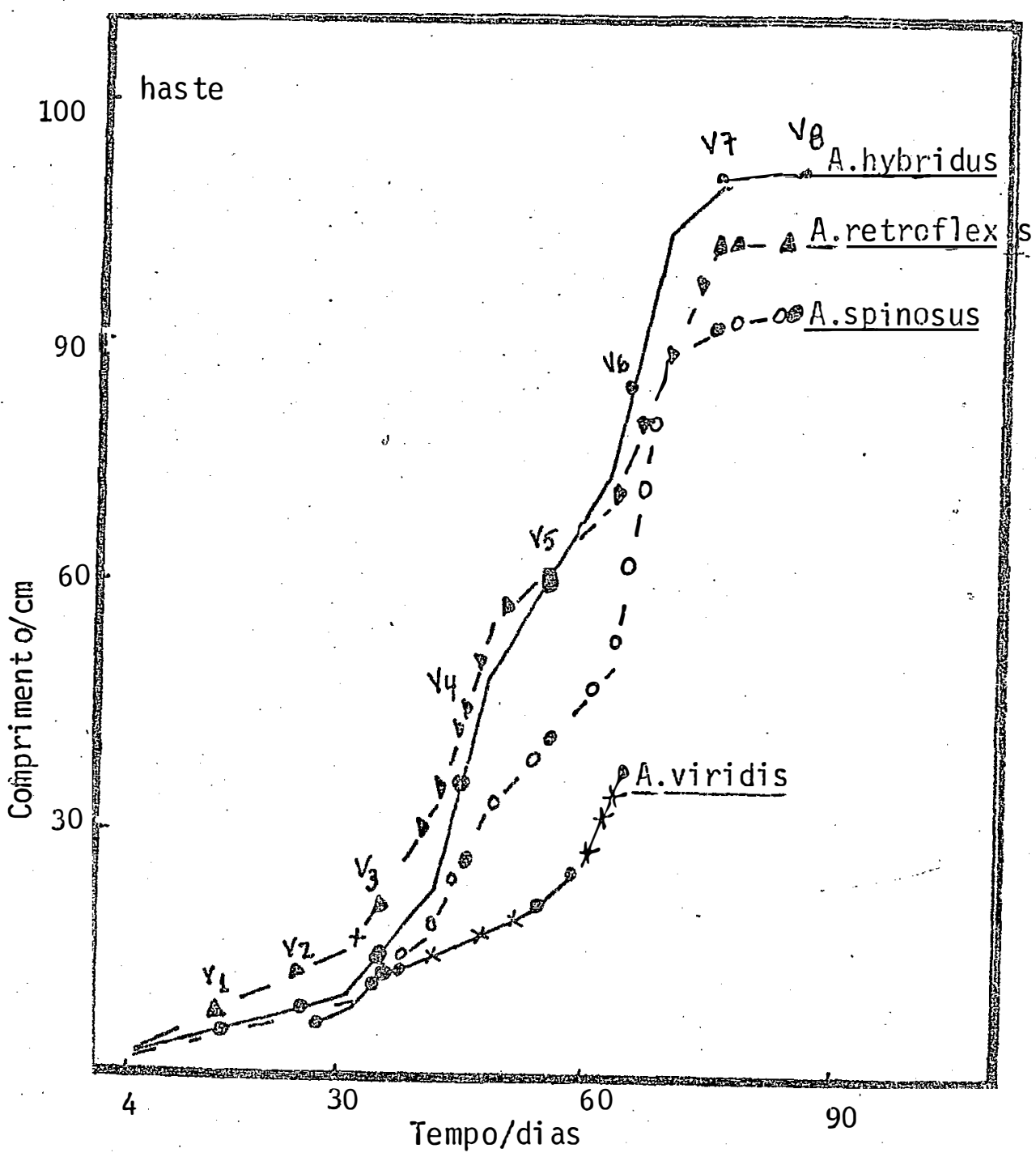

Gráfico 1. Curva de crescimento da haste principal em cm, de A. hybridus (-), A. retroflexus (-..), A. spinosus (-o) e A. viridis $(-*)$ durante o ciclo vital. Ensaio em vasos. Piracicaba, 1983. 


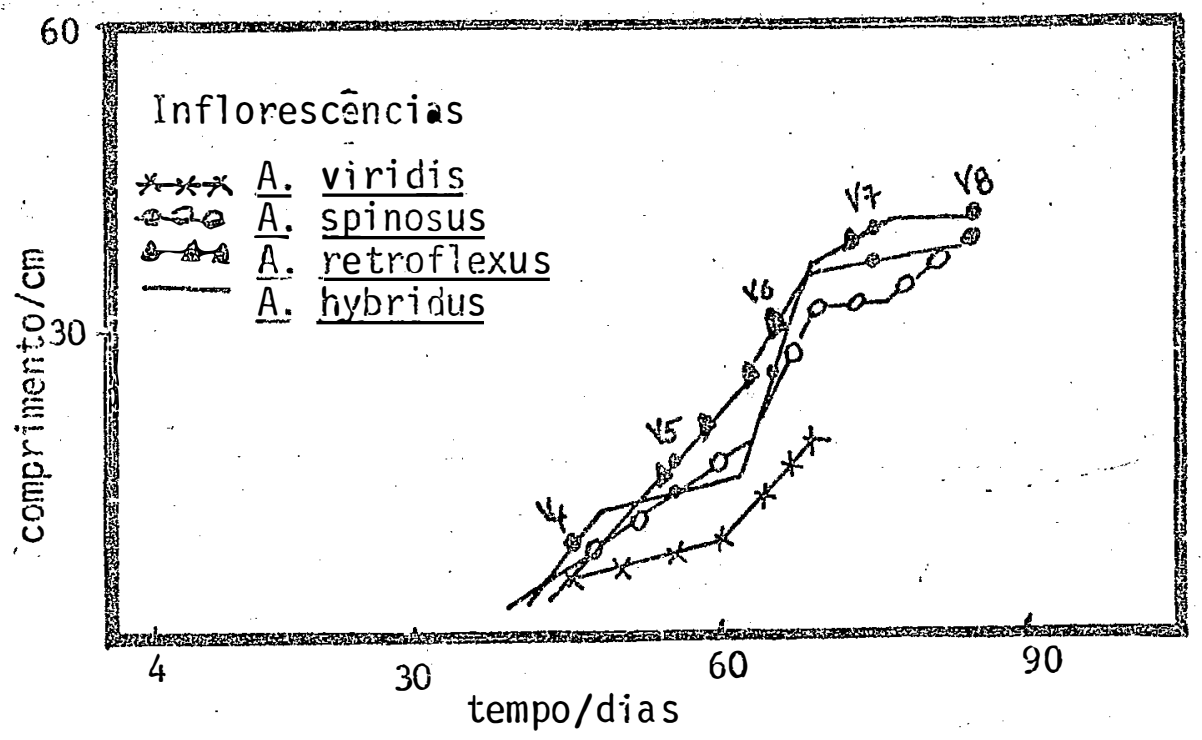

-Gräfico 2. Curva de crescimento da infloréscēncia (em $\mathrm{cm}$ ) principal de A. hybridus, A. retrofiexus, A. spinosus e A. viridis, onde $V_{4}, V_{5} \ldots$ correspondem a taxas de crescimento da inflorescēncia, tomadas em $\mathrm{cm} / \mathrm{dia}$. Ensaio em vasos. Pira cicaba, 1983. 


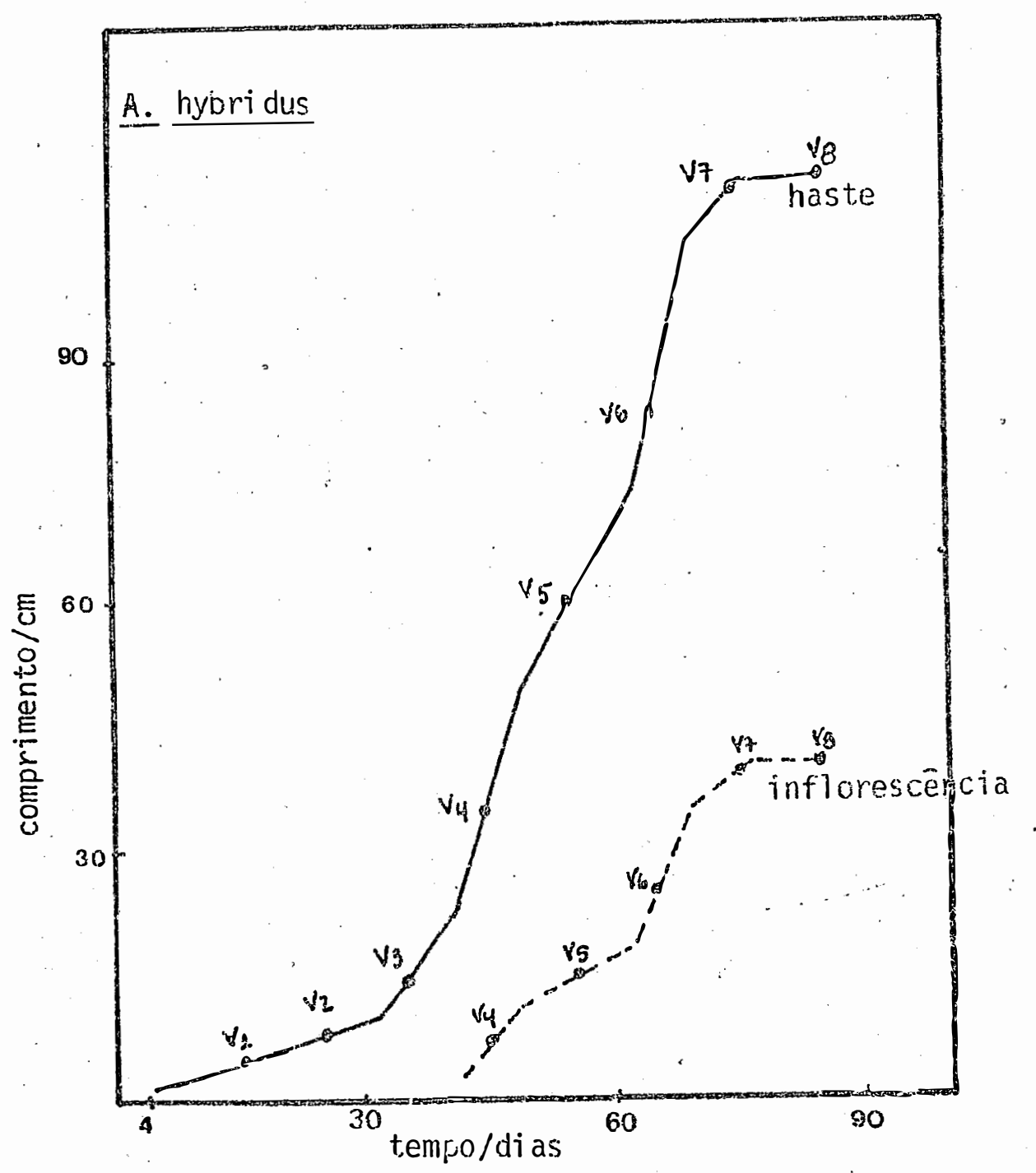

Gräfico 3. Curva de crescimento da haste principal $(\mathrm{cm})$ e da inflorescência $(\mathrm{cm})$ durante o ciclo vital de A. hybridus, onde $v_{1}, v_{2} \ldots$ correspondem äs taxas de crescimento da haste principal e da inflorescéncia, tomadas em $\mathrm{cm} / \mathrm{dia}$. Ensaio em vasos. Pira cicaba, 1983. 


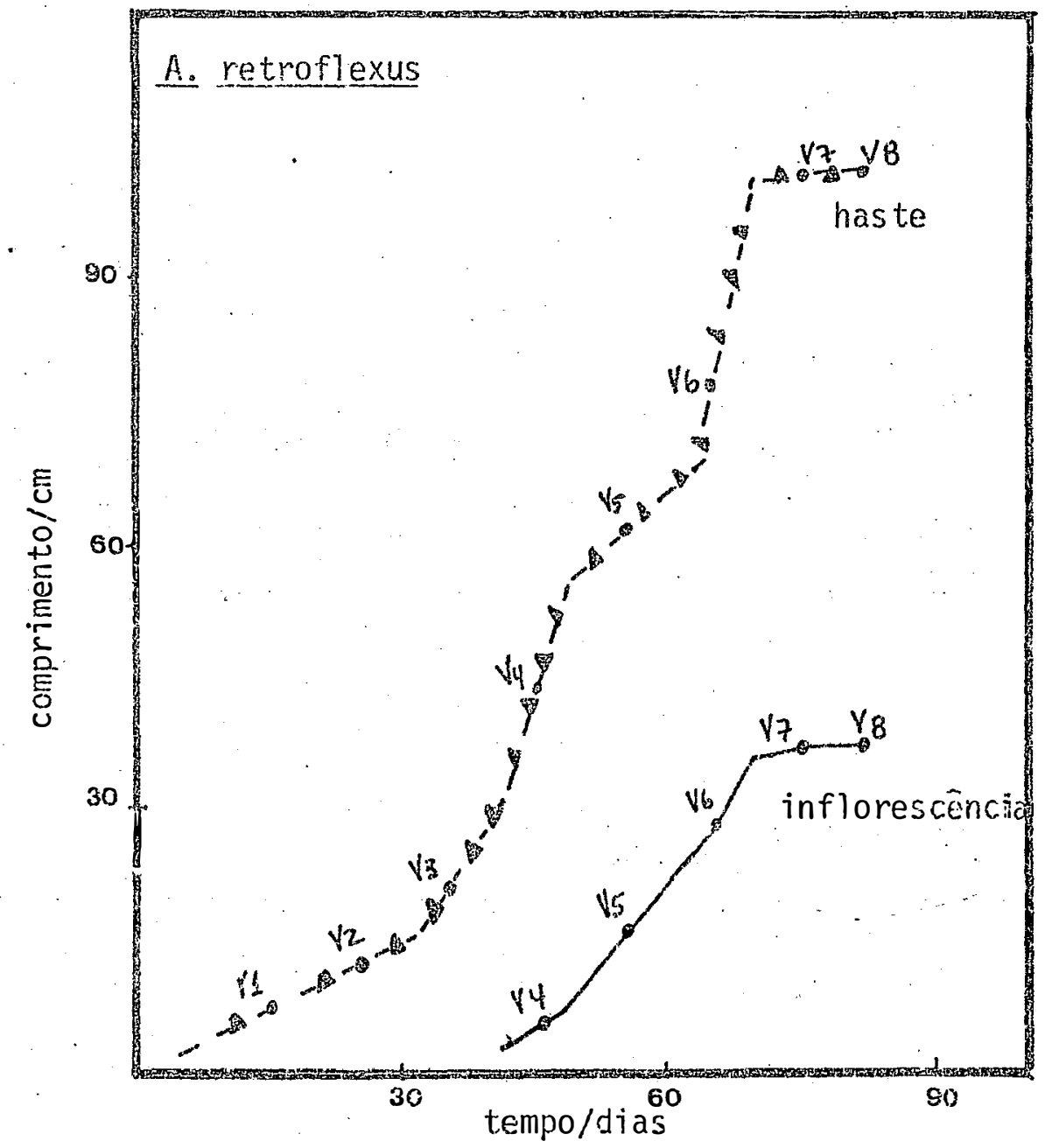

Gräfico 4. Curva de crescimento da haste principal (em $\mathrm{cm}$ ) e da inflorescēncia (em $\mathrm{cm}$ ) durante o ciclo vitalde A. retroflexus, onde $v_{1}, v_{2} \ldots$ correspondem às taxas de crescimento da haste e da inflorescëncia tomadas em $\mathrm{cm} / \mathrm{d}$ ias. Ensaio em vasos. Piracicaba, 1983. 


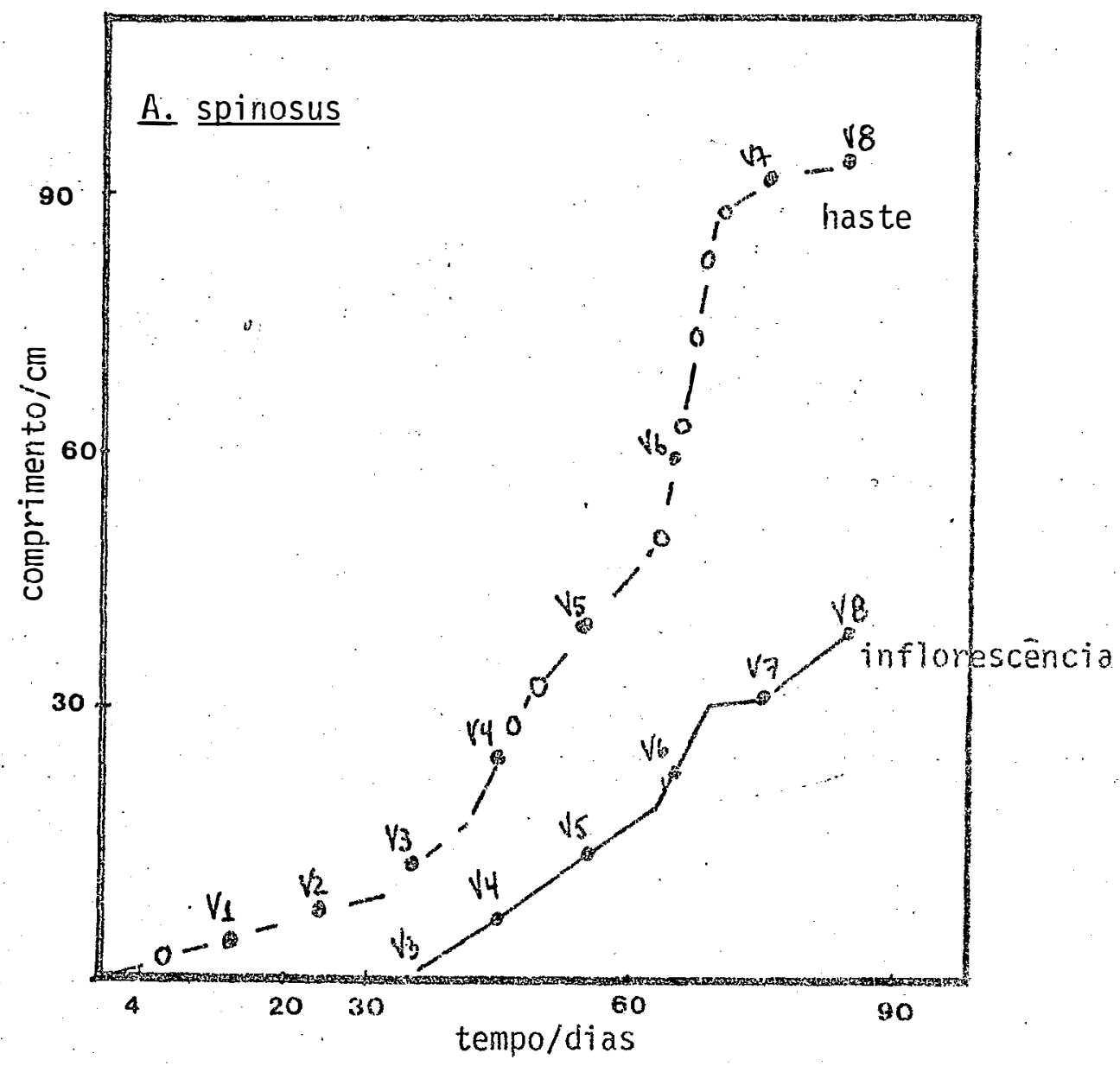

Grāfico 5. Curva de crescimento da haste principal (em cm) e da inflorescëncia $(\mathrm{em} \mathrm{cm}$ ) durānte o ciclo vital de A. spinosus, onde $v_{1}, v_{2} \ldots$ correspondem às taxas de crescimento" da haste principal e da inflorescên cia, tomadas em cm/dias. Ensaios em vasos. Piracicaba, 1983. 


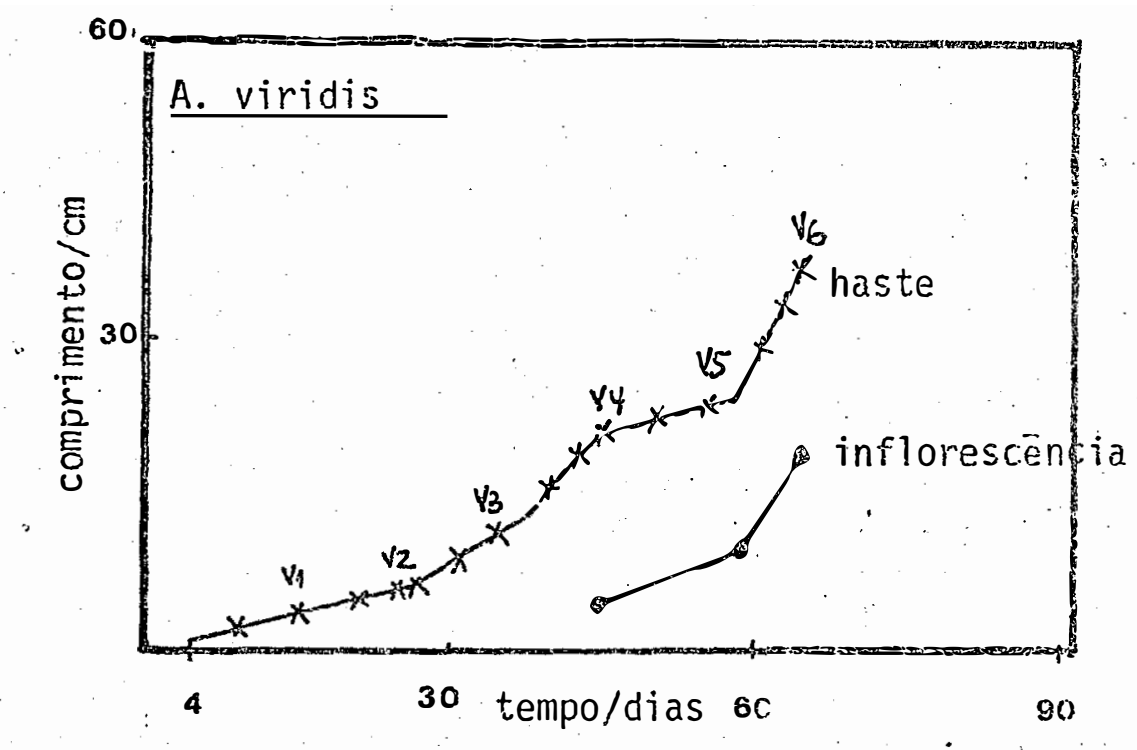

Grāfico 6: Curva de crescimento da haste principal (em cm) e da inflorescéncia (em cm) durante o ciclo vital de A. viridis, onde $V_{1}, V_{2} \ldots$ correspondem às taxas de crescimento tomadas em $\mathrm{cm} / \mathrm{dias}$. Ensaio em vasos. Piracicaba, 1983. 
A anālise da variância do comprimento da haste principa?, comprimento da inflorescência e comprimento da raiz (tabelas 4 e 5 ), a partir dos dados obtidos ao final dos 90 dias, em condições de laboratörio (tabela 3), eviden cia diferenças estatísticas entre as espécies, sendo que o teste de médias (teste de Tukey) revelou diferenças signifi cativas ao nível de $1 \%$ em $A_{0}$ viridis, para as 3 caracteristicas estudadas. Já A. retroflexus e $A$. hybridus não mostra ram diferenças estatîsticas significativas em relação ao comprimento da haste principal, inflorescēncia e raiz, enquanto A. spinosus difere significativamente das 3 outras es pécies estudadas em relação ao comprimento da haste principal e ao comprimento da raiz.

0 grāfico 7.permite a visualização das diferenças detectadas estatisticamente com relação ao comprimen to da haste principal, inflorescència e raizes, para as qua tro espëcies estudadas. A. hybridus e A. retroflexus apresentam-se como um grupo semelhanie, enquanto A. spinosus se situa como um grupo distinto dos demais, o mesmo ocorrendo com A. viridis. Estas diferenças poderiam ser conseqliēncia de diferentes pressões de seleção durante o processo evolutivo destas espécies.

os dados referentes ao peso em gramas, da par te vegetativa (haste, folhas e raizes) e parte reprodutiva (inflorescência + sementes). estão na tabela 6 . Atravēs destes, foi feita anālise da variância e teste de médias (tabe -las 7 e 8, grāfico 8). 0 test de A. viridis com relação às 3 características estudadas.já A. hybridus e A. retroflexus não apresentam diferenças esta tisticas significativas, enquanto $A_{\text {. }}$ spinosus se mostra diferente das outras espēcies com relação ao peso da inflores cência e das raízes.

Atravēs da representação esquemätica do grāfi 
co 8 , estas diferenças se mostram bastante evidentes, levan do à suposição da existiēncia de 3 diferentes padrões na a $\underline{0}$ cação de recursos para A. hybridus, A. retroflexus, A. sp $\underline{i-}$ nosus e $A$. viridis, sendo o grupo semelhante representado pelas espēcies A. hybridus e A. retroflexus.

0 funcionamento da biomassa entre ramos + inflorescência, inflorescēncia + sementes e raïzes (tabela 9 , grāfico 9) é de interesse especial como medida do esforço reprodutivo. Estes valores (esforco reprodutivo) variaram de $27,8 \%$ a $43 \%$, sendo que a espécie que mostrou o menor valor $(27,8 \%)$ foi A. spinosus, que se caracterizou no estudo do ciclo vital como a espęcie mais tardia.

os molelos de alocação de recursos de A. hybri dus, A. retroflexus e A. viridis são semelhantes e destinam frações altas de sua energia para atividades reprodutivas $(40,3 \% ; 43,0 \% ; 44,3 \%$, respectivamente).

De acordo com a bibliografia, os conceitos de estrategista $r$ e $k$ não são absolutos. mas sim relativos,sen do que, de uma maneira geral, os genōtipos $r$ apresentam um maior nümero de descendentes, maturidade sexual precoce e um ciclo de vida curto (Pianka, 1970; Gadgil e Solbrig, 1972). os dados obtidos no presente trabalho se encaixam nesta pre missa e, embora em termos gerais, as quatro espēcies apre sentem caracteristicas de estrategistas - $r$, o A. spinosus se apresenta de uma forma relativa como uma espëcie $k$ (ciclo de vida mais longo, menor fração de sua energia sendo a locada em atividades reprodutivas) enquanto A. hybridus, A. retroflexus e A. viridis se situam como estrategistas - $r$.

Por outro lado, a distribuição da biomassa en tre os värios orgãos vegetativos das plantas, deve depender em grande parte, da natureza dos recursos limitantes, como 
nutrientes, ägua, luz, etc., sendo que as condições de expe rimentação a que foram submetidas as plantas pressupunha que nã estivessem ocorrerido limitaçöes ao potencial de crescimento destas. Porēm, em condições de vaso, sempre ocorre um prejuizo ao desenvolvimento radicular.

Merece destaque o fiato de que os menores valo res de esforço reprodutivo encontrados em A. spinosus. são contrabalançados por valores maiores na energia alocada para as raizes $(17,1 \%)$, indicando que a planta explera com in tensidade os recursos que lhe advëm do solo.

Os coeficientes de variação (CVs) da porcenta gem de energia alocada para diferentes atividades (tabela 9, gräfico 9), evidenciam diferenças acentuadas entre os espēcies estudadas quanto a respostas às condições experimentais a que foram submetidas e, por outro lado, refletem a hetero geneidade genética e plästica das espécies (Haupti e jain, 1978).

os valores mais altos do coeficiente de varia ção foram apresentados por A. viridis, sendo que esta espëcie sofreu durante seu ciclo vital alia incidencia de pragas e doenças. A caracteristica que mostrou cV mais alto em todas as espécies foi a porcentagem de biomassa alocada para as raizes (tabela 9), levantando a hipótese de que as plantas, nas condições de cultivo a que foram submetidas, so freram pressões em seu desenvolvimento radicular.

Não obstante seja geralmente dificil, obter coeficientes de variaçäo razoăveis para peso de matéria ver de e peso de matéria seca em plantas (Green et al, 1952; Mar tins e Vello, 1983), seria de se esperar que o emprego de um maior número de plantas por repetição pudesse conduzir a um maior controle das influencias ambientais. 


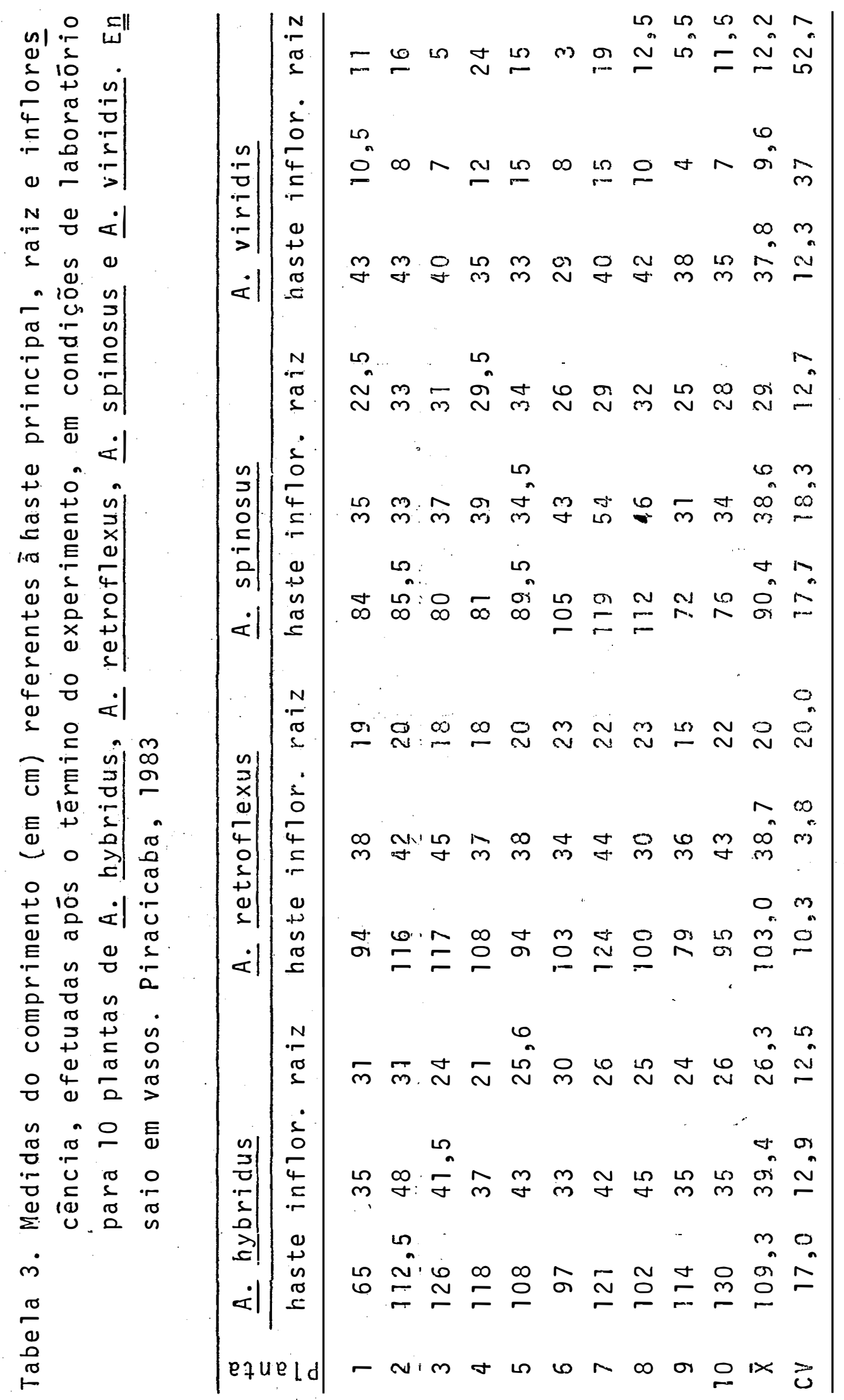




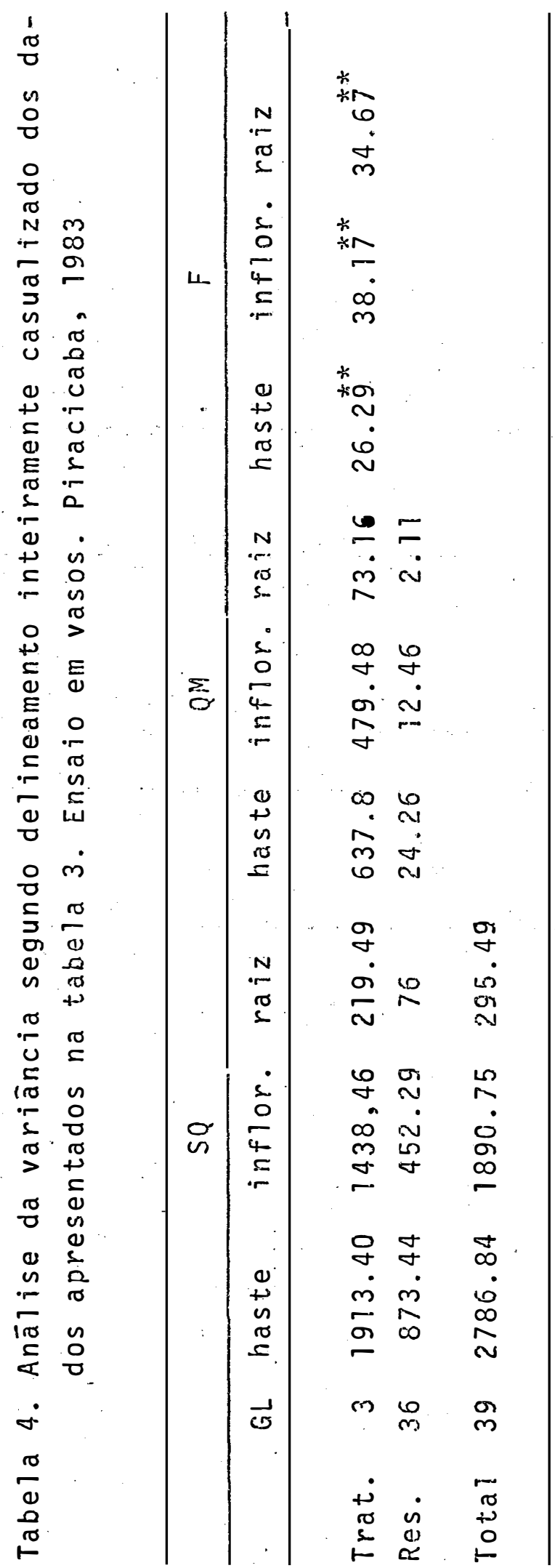




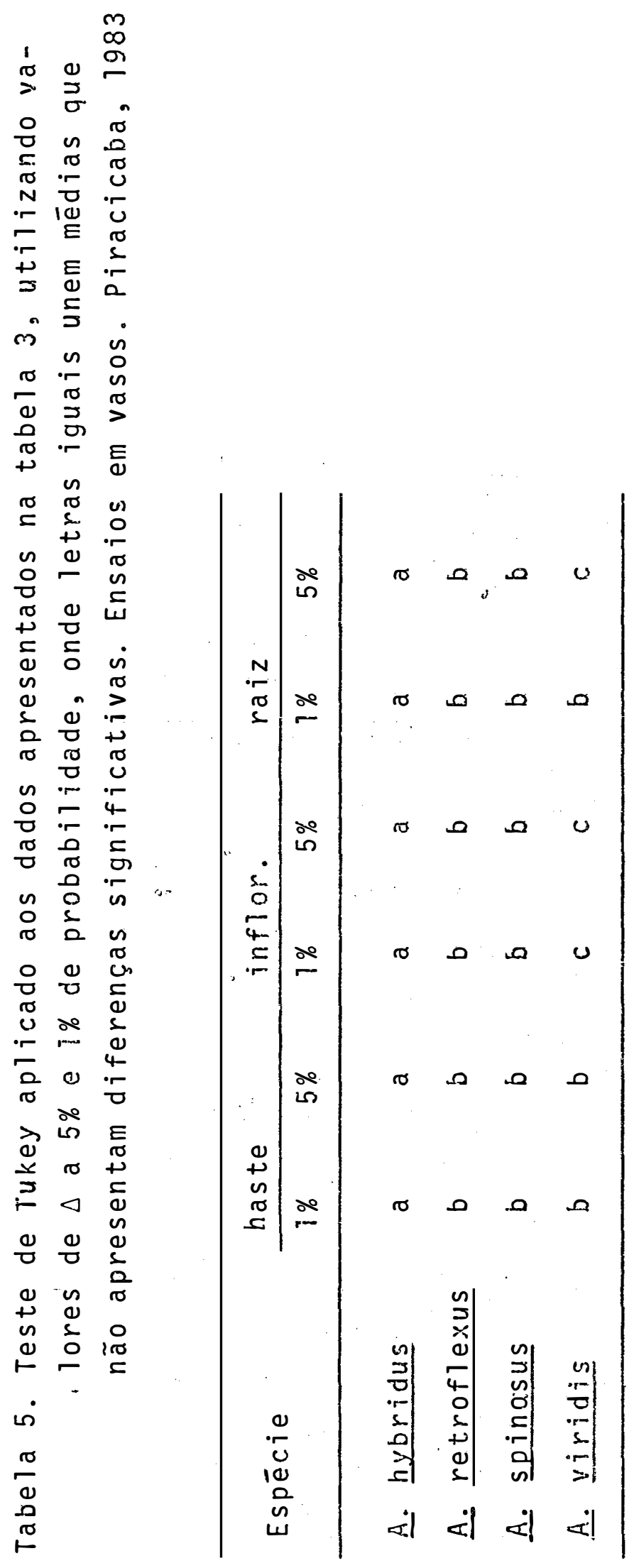




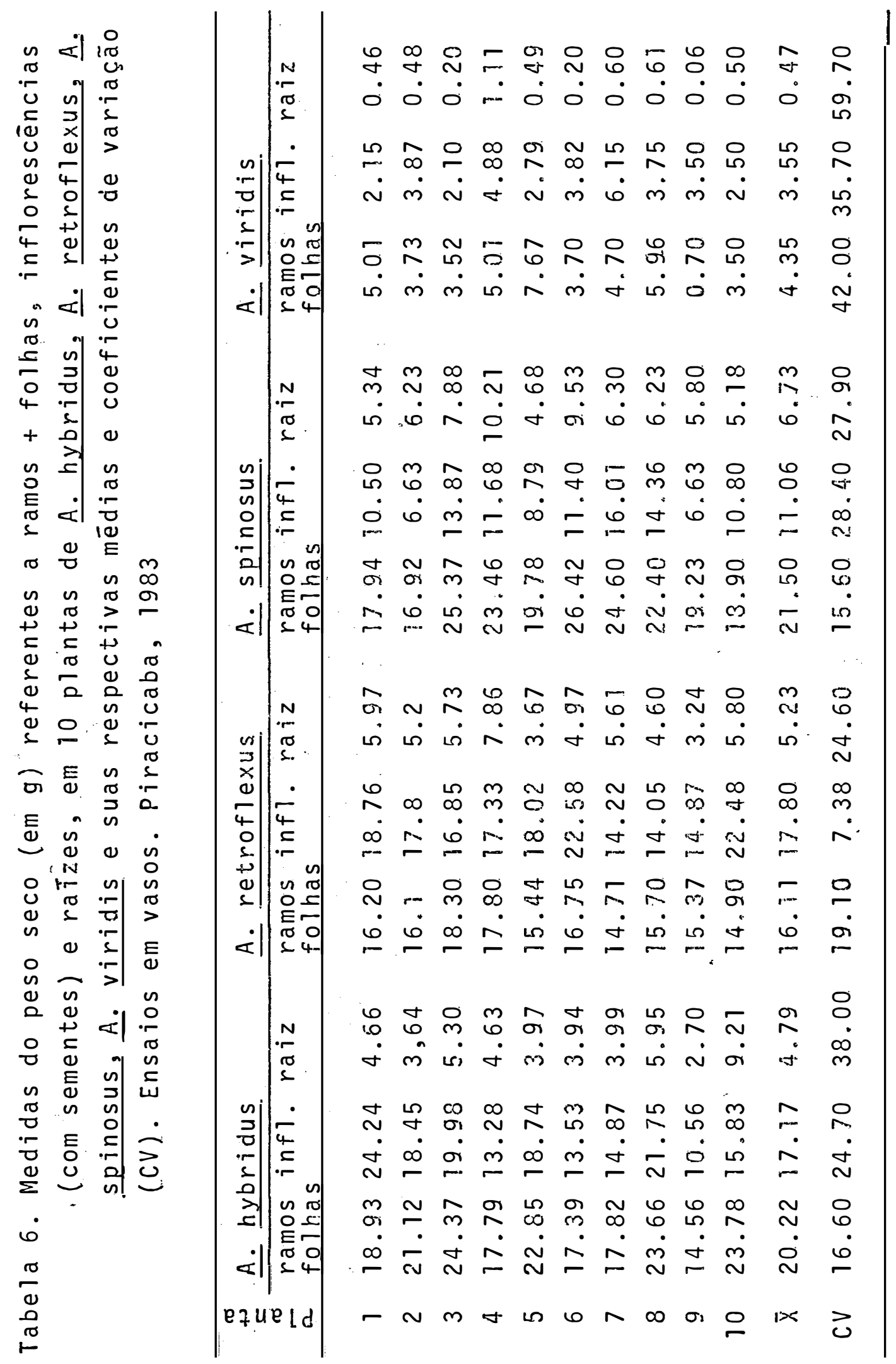




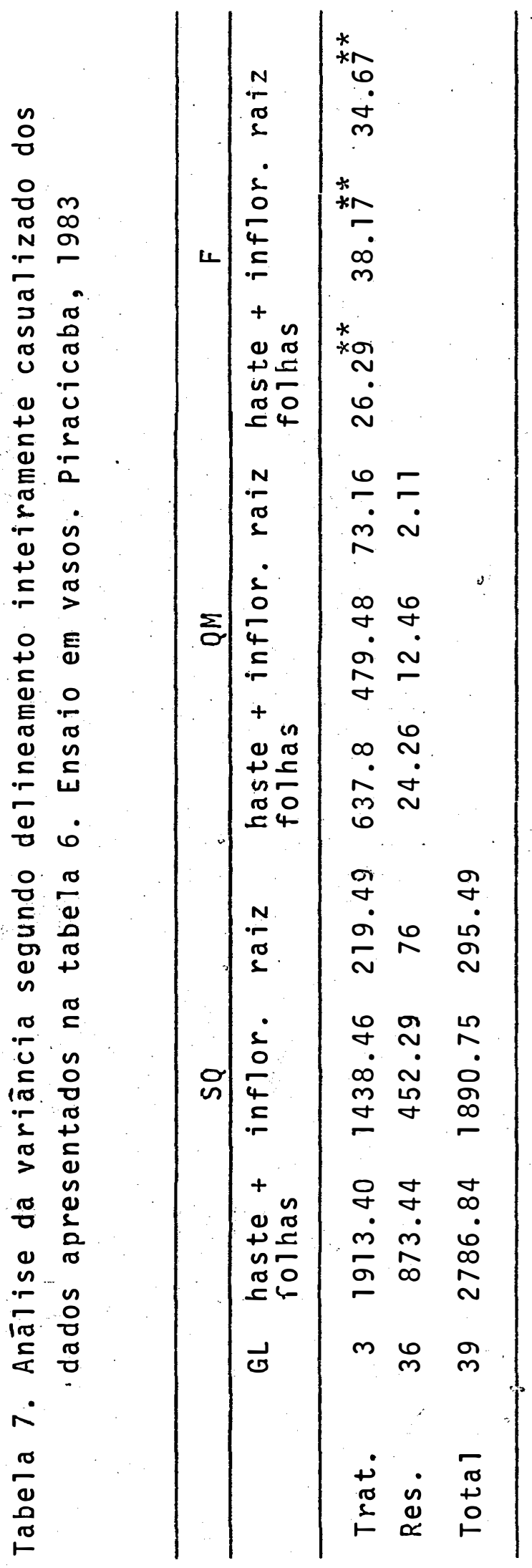




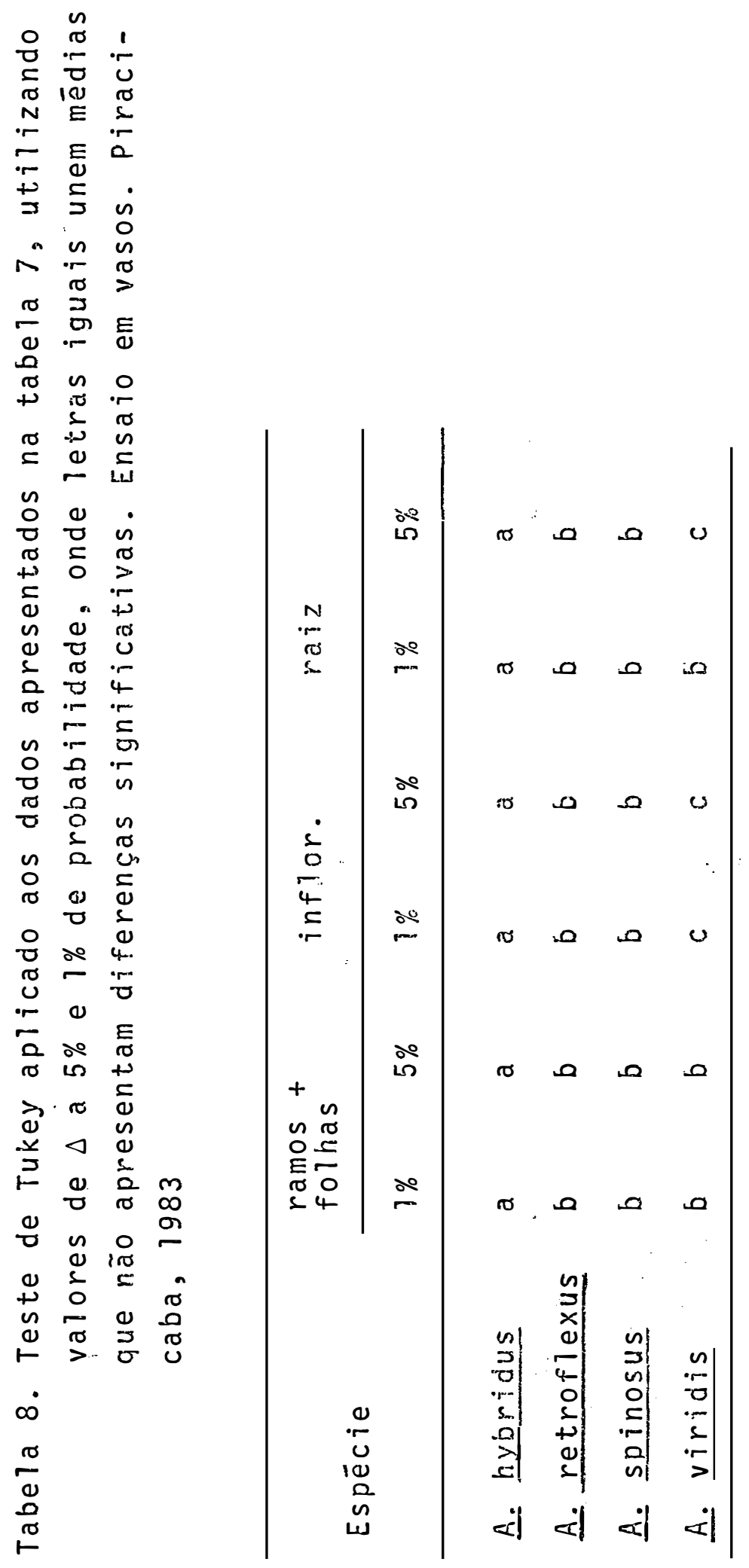




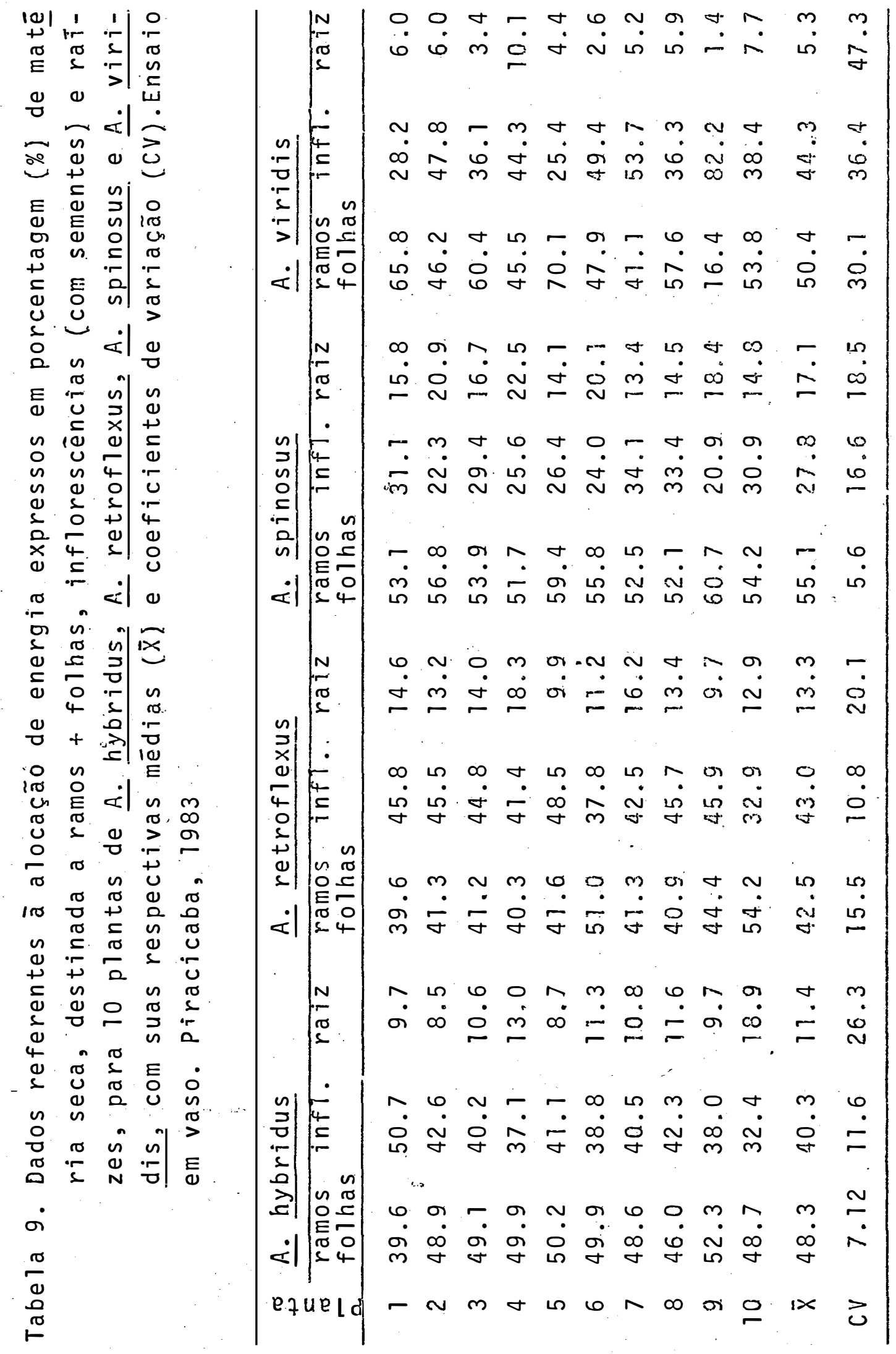




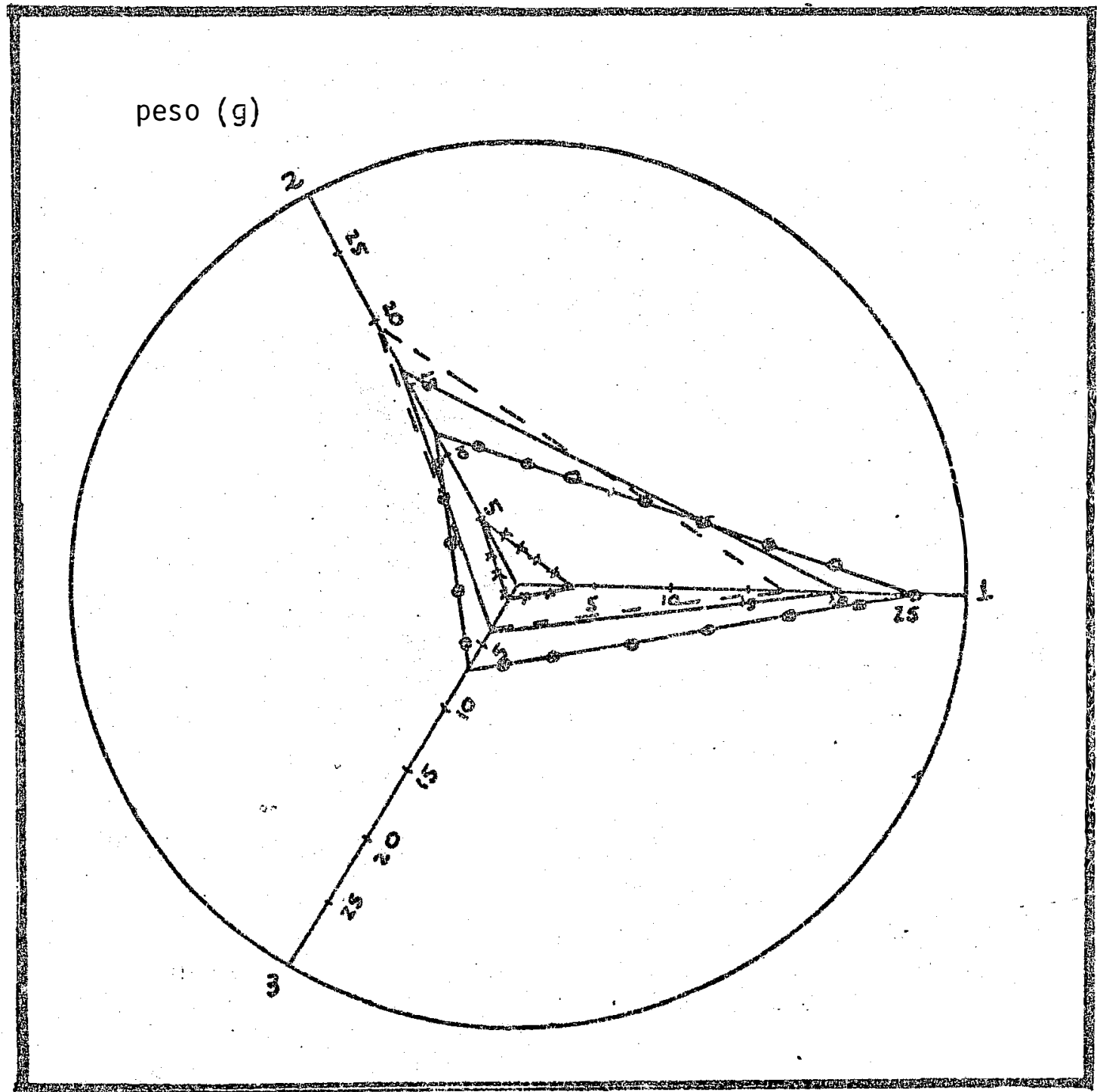

$\rightarrow \rightarrow$ A. viridis

A. hybridus

A. spinosus

...... A. retrofiexus

1. haste

2. inflorescëncia

3. raizes

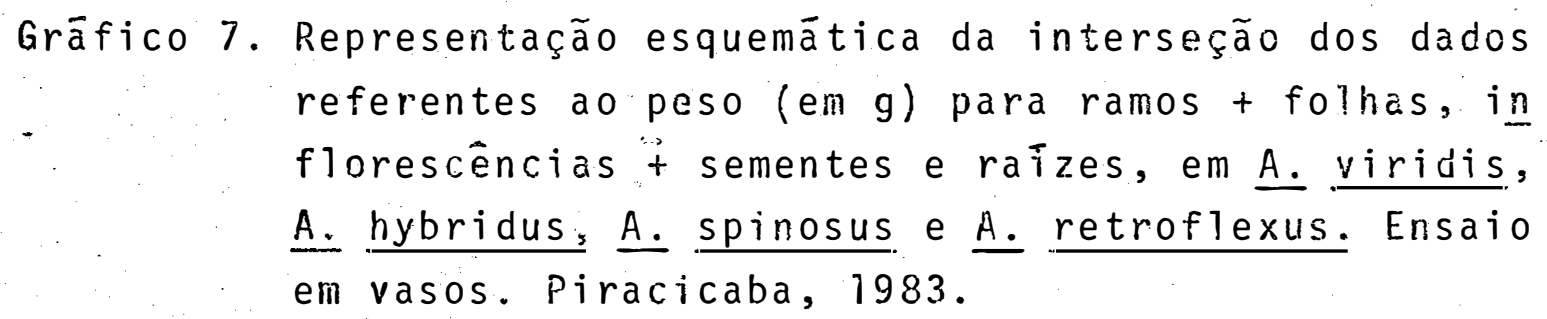




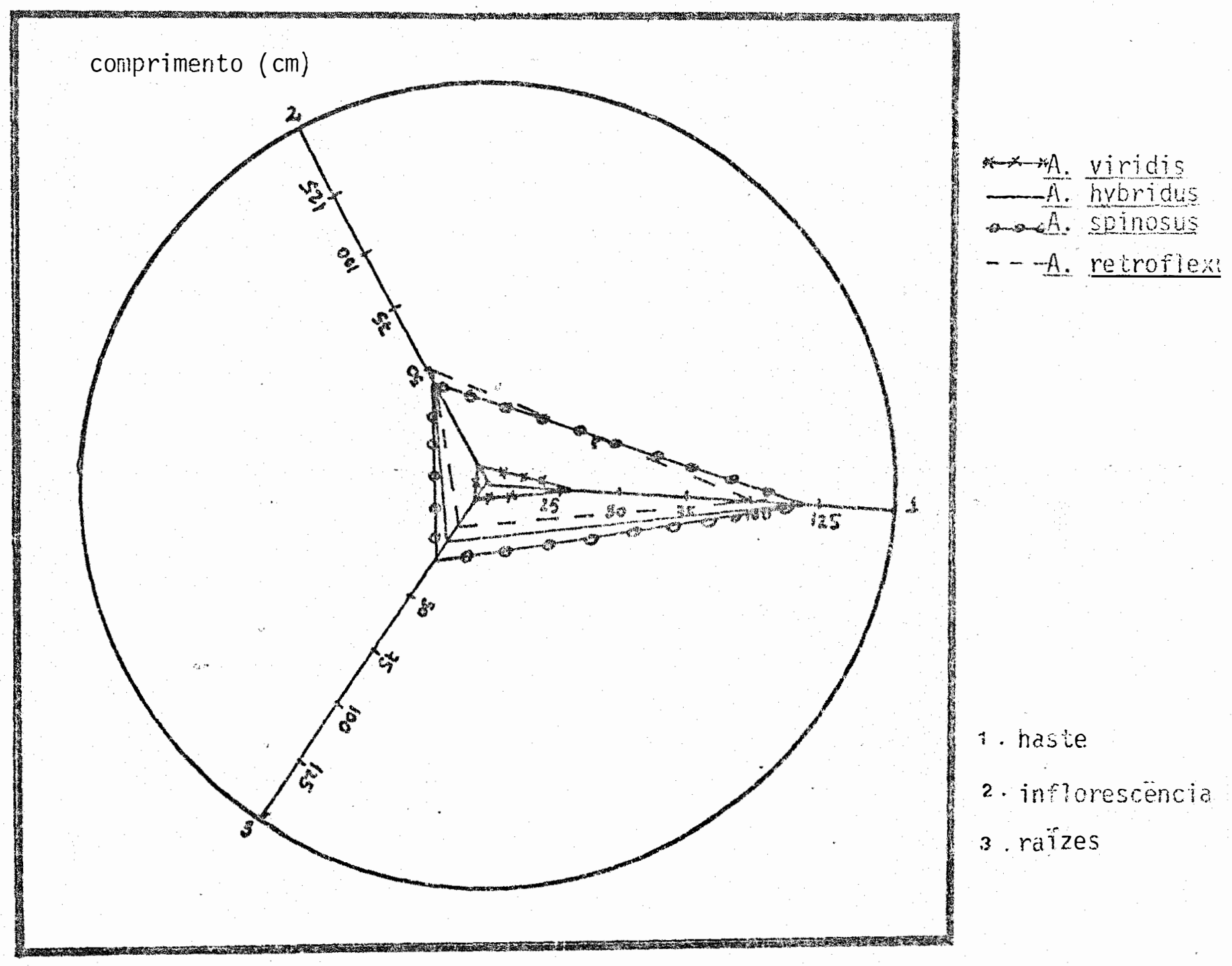

Gräfico 8. Representação esquemātica da interseção dos dàdos referentes a comprimento (em $\mathrm{cm}$ ) para haste, inflorescéncia e raiz principais, em A. viridis, A. hybridus, A. spinosus e A. retroftexus. Ensaio em vasos. Piracicaba, 1983. 


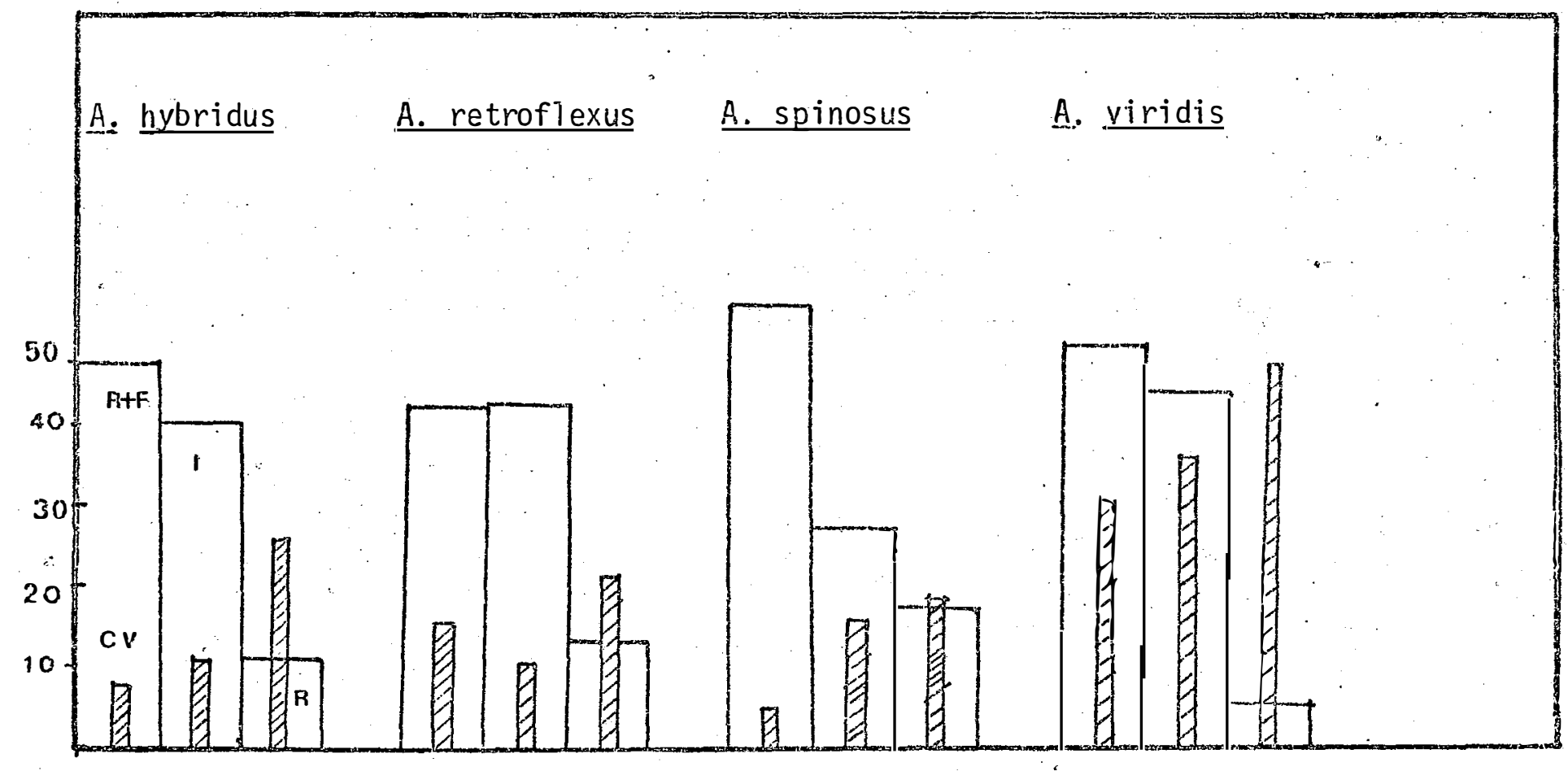

Grāfico 9. Comparação esquemătica da alocação de energia (\%) utilizando-se a média dos dados apresentados na tabela 9 e seus respectivos coeficientes de varia ção. Ensaio em vasos. Piracicaba, 1983. 


\subsection{Estudo de aspectos da dinämica populacional}

4.2.1. Estudo referente a populações naturais de A. hybridus e A. deflexus.

Algumas considerações descritivas resultantes da observação da população natural de A. hybridus e A. deflexus merecem destaque como suporte à compreensão da estru tura populacional destas duas espécies.

$\mathrm{Na}$ população estudada observou-se presença de maior nūmero de individuos de A. hybridus (cerca de 7 plantas $/ \mathrm{m}^{2}$; tabela 10 l, que consistia de plantas bastante vigorosas, caracterizadas por um marcante crescimento vertical e presença de grandes inflorescências. Jā o $\underline{A}$. deflexus apa recia em pequeno nūmero de individuos (aproximadamente 1,3 plantas $/ \mathrm{m}^{2}$, tabela 10 ), ocupando estrato prōximo ao solo e hābito de crescimento prostrado e radial. Na zona central da ārea de distribuição de $\underline{A}$. deflexus, aparecia em pequeno nü mero, "enquanto nas zonas marginais tornava-se mais abunciante.

observa-se que, com relação ao esforço reprodutivo, os valores médios foram maiores para $A$. hybridus do que para $\underline{A}$. deflexus, embora a diferença entre eles seja pe quena (tabela 11). Por outro lado, o coeficiente de variação do esforço reprodutivo em $\underline{A}$. deflexus foi bastante alto $(45,4 \%)$, sendo esta uma indicação da heterogeneidade na constituição da amostragem, que por sua vez, reflete a hete rogeneidade dos indivĩduos na população. Em A. hybridus, 0 çoeficiente de variação do esforço reprodutivo foi pequeno $(10,5 \%)$ indicando uma maior uniformidade dos indivíduos des ta espécie na população estudada.

Foi constatada a presença de muitos insetos voadores pousando nas inflorescéncias de $A_{-}$hybridus, sendo 
que, nas primeiras horas da manhã, havia abundância de peque nas abelhas que, com o passar do tempo, deram lugar a abelhas maiores. Foram observados ninhos de pássaros em A. hybridus, que provavelmente, alimentam-se de suas sementes,bas tante abundantes.

Em trabalho realizado por Bialoskorski e Martin (1981), utilizando espēcies de Amaranthus, foi constatado que a luz e a temperatura são fatores ecológicos importan tes para a germinação das sementes. Os dados obtidos indicaram que, de maneira geral, a ausência de luz e temperaturas alternadas foram as condições que resultaram em maiores porcentagens de germinação: Conseqlientemente, em condições natu rais, é necessārio que a semente atinja uma camada do soro que impeça a presença de luz.

No teste de germinação utilizando as sementes das procedências específicas deste trabalho, em condições de ausência de luz e temperatura constante de $25^{\circ} \mathrm{C}$, ficou constatado que $\underline{A}$. hybridus apresentava um espaço de tempo de 3 dias para iniciar sua germinação e após 15 dias, cerca de $52 \%$ das sémentes haviam germinado. No caso de A. deflexus, 0 inīcio da germinação ocorreu em dois dias e apōs 15 dias,82\% delas haviam germinado.

Por um lado, existe a possibiliciade das sementes de A. hybridus. e A. deflexus terem perdido o seu vigor devido ao armazenamento de aproximadamente um ano e meio, em - câmara seca. Mas, existe tambēm a hipōtese de que a espēcie A. hybridus disponha de mecanismo de dormência em suas semen tes, que influencie na formação e manutenção da estrutura po pulacional, uma vez que os indices de germinação encontrados em A. deflexus, que tambēm sofreu armazenamento, foram signi ficativamente maiores que em A. hybridus. 
4.2.2. Caracterização da competição intraespecîfica

os dados apresentados no presente experimento foram coletados ao final do ciclo vital, quando a hierarquia populacional já estava estabelecida e se constituia de poucas plantas mais "fortes", rodeadas de um grande nümero de plantas pequenas e fracas. Em condições experimentais de va sos, sob pressão de competição intraespecífica, as espēcies A. hybridus e A. deflexus apresentaram arquitetura de planta semelhante à encontrada em condições naturais, embora pro porcionalmente inferiores.

os dados relativos à porcentagem de sobrevi vência (tabela 12, gráfico 10) indicam um aumento da mortalidade devido ao stress populacional, tanto em A. hybridus como-em A. deflexus. Porëm, a severidade do "self-thinning" foi maior em A. hybridus, indicando ter esta espēcie uma mortalidade dependente da densidade mais acentuada em compa ração com o A. deflexus, nas condiçöes experimentais a que foram submetidas:

Na tabela 12, gräfico 11, é possível observar que, na medida em que o número mēdio de plantas sobreviventes aumenta, devido ao aumento da densidade de semeadura, $\underline{0}$ corre uma diminuição do peso médio por planta, nas duas espécies estudadas. Consequentemente, o aumento da densidade acarreta um incremento da mortalidade de plantas e uma redu ção na taxa de crescimento individual (plasticidade) em A. deflexus e A. hybridus.

Porém, no que se refere à produção de matēria seca total (tabela 13), os dados médios obtidos para A. deflexus obedecem a Lei da Produtividade Final Constante de Kira et al (1953). Em contrapartida, a porcentagem de sobre vivencia diminue, indicando uma limitação na disponibilidade clos recursos do meio. No caso do A. hybridus, ocorre um 
aumento da produtividade total de matéria seca em densidade baixa $(d=6)$. Este fato pode encontrar sua justificativa no häbito de crescimento ereto desta espécie, que permite uma maior captura da energia solar, acrescido de uma maior disponibilidade por planta individuai, dos recursos nutricionais do solo, quando em baixa densidade.

A porcentagem de alocação de energia, medida atravēs do peso dos ramos + folhas, infiurescências + semen tes e raizes, indica para A. hybridus (tabeia 14, gräfico 12) um aumento da alocação de energia para ramos t folhas na me dida em que ocorre um aumento da densidade popuracional. Pa ra Abrahamson (1979) a distribuição da biomassa para os diversos ōrgãos vegetativos irā depender, em grande parìe, da natureza dos recursos limitados (ex. nutriente, ägua, luz, etc.). Neste caso, parece evidente que, a nivel intraespecí fico, as espëcies de A. hybridus competem ativamente na bus ca de uma maior captação da energia solar. A consequência desta competição é uma maior alocação de recursos no cresci mento vegetativo da haste principal.

Em contrapartida, pode-se observar a través do gräfico 12, que o aumento da alocação de recursos para ramos + folhas em A. hybridus, submetido a crescentes pressões de densidade, implica numa diminuição do esforço reprodutivo e da energia destinada ao desenvolvimento radicular. Entretanto, conforme se aumenta a densidade, a proporção de $\underline{a}$ locação dos produtos assimilados para os diferentes órgãos - da planta, mida (Harper, 1961). Através do gráfico 12, observa-se, no que se refere à energia alocada para inflorescēncias + sementes e raỉzes, uma tendēncia de $\underline{\text { A. hybridus a }}$ apresentar uma equivalēncia na distribuição dos recursos pa ra estas duas atividades. Na densidade māxima $(d=96)$, as proporções alocadas para raízes ē exatamente a mesma que pa ra inflorescència. 
Em A. deflexus, o comportamento das plantas submetidas a pressões de densidade crescentes, foi o oposto da espëcie A. hybridus (tabela 14, gräfico 12). Com o aumen to da densidade, ocorreu uma progressiva diminuição da ener gia alocada para ramos + folhas, enquanto o esforço reprodu tivo aumentou.

Analisarido este resultado atravēs da ótica do conceito de estrategista - $r$, e de que diferenças no esforço reprodutivo indicam diferentes compromissos adaptativos. (Harper, 1977), a espécie A. deflexus apresenta comportamen to tipico de estrategista $r$. Vem colaborar com esta premissa o fato de que $\underline{A}$. deflexus apresentou durante o seu ciclo vital precocidade na germinação, florescimento e duração do ciclo vital, quando em comparação com A. hybridus. Por outro lado, a espécie A. hybridus apresenta uma tendência em alocar recursos para atividades competitivas (ramos + folhas) em detrimento das atividades reprodutivas (estratiegista-k) na medida em que ocorre um aumento ca densidade popuiacional intraespecífica.

4:2.3. Caracterização da competição interespecîfica

Com o desenvolvimento do ciclo vital das pian tas, as relações de vizinhança, a distância entre os indivi duos e o tempo no qual eles se estabeleceram, são variáveis dificeis de serem analisadas experimentalmente. No presente experimento, os dados foram tomados ao final do ciclo vital -e pretendem estabelecer as tendéncias manifestadas pelas es pécies A. deflexus e A. hybridus, quando em competição interespecīfica em vasos. A variāvel básica utilizada foi o peso seco medido em gramas, destinado à parte vegetativa (ra mos + folhas) e parte reprodutiva (inflorescência + semen tes). Destes dados, foram obtidos a porcentagem de alocação de energia para atividades vegetativas, o esforço reproduti 
vo e a produtividade relativa individual e total.

No que se refere à porcentagem de sobrevivència (tabela 15, grāfico 13) observa-se que a espēcie A. deflexus foi mais afetada devido a pressões de competição interespecífica. Por outro 1 ado, a espécie $A$. hybridus manteve uma porcentagem de sobrevivencia relativamente constante, mesmo com o aumento da competição interespecîfica. Una vez que estes dados foram obtidos ao final do ciclo vital, seria necessārio conhecer em qual fase do ciclo que a competi ção interespecífica estaria agindo no sentido de diminuir a sobrevivencia de A. defiexus:

Para Grime e Jeffrey (1965), citados por Parsons (1968), a sobrevivência de plàntulas tolerantes à sombra, em baixa intensidades de luz, está correlacionada a bej xas taxas de crescimento. Ele sugere que a adaptação ä sonj-bra envolve seleção para baixa respiração e baixas taxas me tabōlicas:

Este caso se apresenta importante, pois o A. deflexus é a espécie que habita os estratos inferiores, prö ximos ao solo, que são sombreados, enquánto o A. hybridus, com seu crescimento tipicamente vertical, ocupa os estratos superiores, captando maior quantidade cie energia solar.

Analisando-se a produtividade média de matēria seca total, para ramos + folhas e inflorescências + sementes (tabela 16, gráfico 14), observa-se que a produção de biomassa de A. deflexus $_{\text {d }}$ caiu devido a crescentes pressões competitivas interespecifficas, enquanto 0 A. hybridus manteve sua produção de bỉomassa relativamente estāvel na presença das mesmas pressões.

Porēm, o grāfico obtido (grāfico 16) encaixa-se no modelo IV proposto por Harper (1977), Wit (1960) co 
mo metodologia de anālise de experimentos por substituiçäo. Este modelo descreve situações em que, por uma razão ou outra, as espëcies escapam da competição. Significa que o cres cimento de $A_{0}$ deflexus requer recursos limitantes do ambien te diferentes dos requeridos pelo A. hybridus.

Porēm, o estudo de algumas espécies sob diver sas condições amientais demonstrou que a produtividade áa mistura comumente excede levemente a produtividade média dos stands puros. Entretanto, o cultivo em vasos quase certamen te força a espëcie a usar o mesmo espaço e recursos do solo, enquanto no campo, diferentes espëcies podem penetrar diferentes zonas com suas raizes e escapar de alguma forma do stress interespecifico (Harper, 1977).

Os dados mëdios percentuais da alocação de energia para atividades vegetativas e reprodutivas (tabela 17, grä́fico 15) revelam para A. deflexus uma certa constäncia neste padrão de alocação para as duas atividades, em decorrência do aumento do stress competitivo interespecifico, enquanto A. hytridus manifesta uma maior variação neste padrão. A média do esforço reprodutivo nos quatro tratamentos evidencia para A. deflexus um maior valor $(35,8 \%)$ do que pa ra A. hybridus $(25,7 \%)$. Para Harper (1977), as diferenças nas capacidades reprodutivas das plantas representam diferen tes compromissos adaptativos. A seleção natural age de forma a otimizar estes compromissos e maximizar a adaptabilida de individual.

0 caso estudado constitue--se da adaptabilidade das espécies a diferentes estratos espaciais, visando a captura da energia solar, sendo que a espēcie que ocupa os estratos superiores (A. hybridus) deverä conseqüentemente, a locar mais energia para atividades vegetativas, em detrimento das atividades reprodutivas. 
0 A. deflexus, alëm de apresentar uma maior fração de seus recursos para atividades reprodutivas, apresenta uma precocidade na germinação, inĩcio de florescimento e duração do ciclo vital quando em competição intra e in terespecifica com A. hybridus.

A tabela 18, grāfico 15, revela para $\underline{A}$. defle xus e A. hybridus, valores médios de PTR $>1,0$. De acordocom metodologia de anālise proposta por Wit (1960) e Harper (1977), valor de PTR = 1,0 implica que as duas espécies es:tão demandando os mesmos recursos limitados do ambiente.

Quando PTR > 1,0 , sugere que as espëcies deman dam recursos diferentes do ambiente, evitando çompetição en tre elas e o valor de $P T R<1,0$ implica em antagonismo mútuo.

0 modelo grāfico da produtividade totà de ma téria seca (grāfico 14) está em concordānciá com a metodoló gia de anālise através da produtividade cotal relativa. Estes dọis modelos descrevem situações em que as espécies se harmonizam na medida em que expioram recursos diferentes do ambiente. No caso, o A. hybridus apresenta crescimento vertical e consequentemente, capta maior quartidade de energia solar, enquanto o A. deflexus, através do crescimento radial e ocupando estratos próximos ao scio, deve ter desenvol vido mecanismos de adaptabilidade a condições de sombra.

Merece destaque o fato de que, quanto à estru tura radicular, nada foi observado criteriosamente neste trabalho. E provāvel que existam interações a nível de distribuição do sistema radicular que acrescente dados para compreensão de como as espécies A. deflexus. e A. hybridus de mandam diferentes recursos do meio e escapam da competição interespecifica.

Um outro fato que deverā ser analisado $\bar{e} \quad$ a 
baixa sobrevivência de A. deftexus (tabela 15, gräfico 13). Este dado estā de acordo com as observações de populações naturais (tabela 10 ) onde se evidenciou a presença mais den sa de A. hybridus do que A. deflexus. 


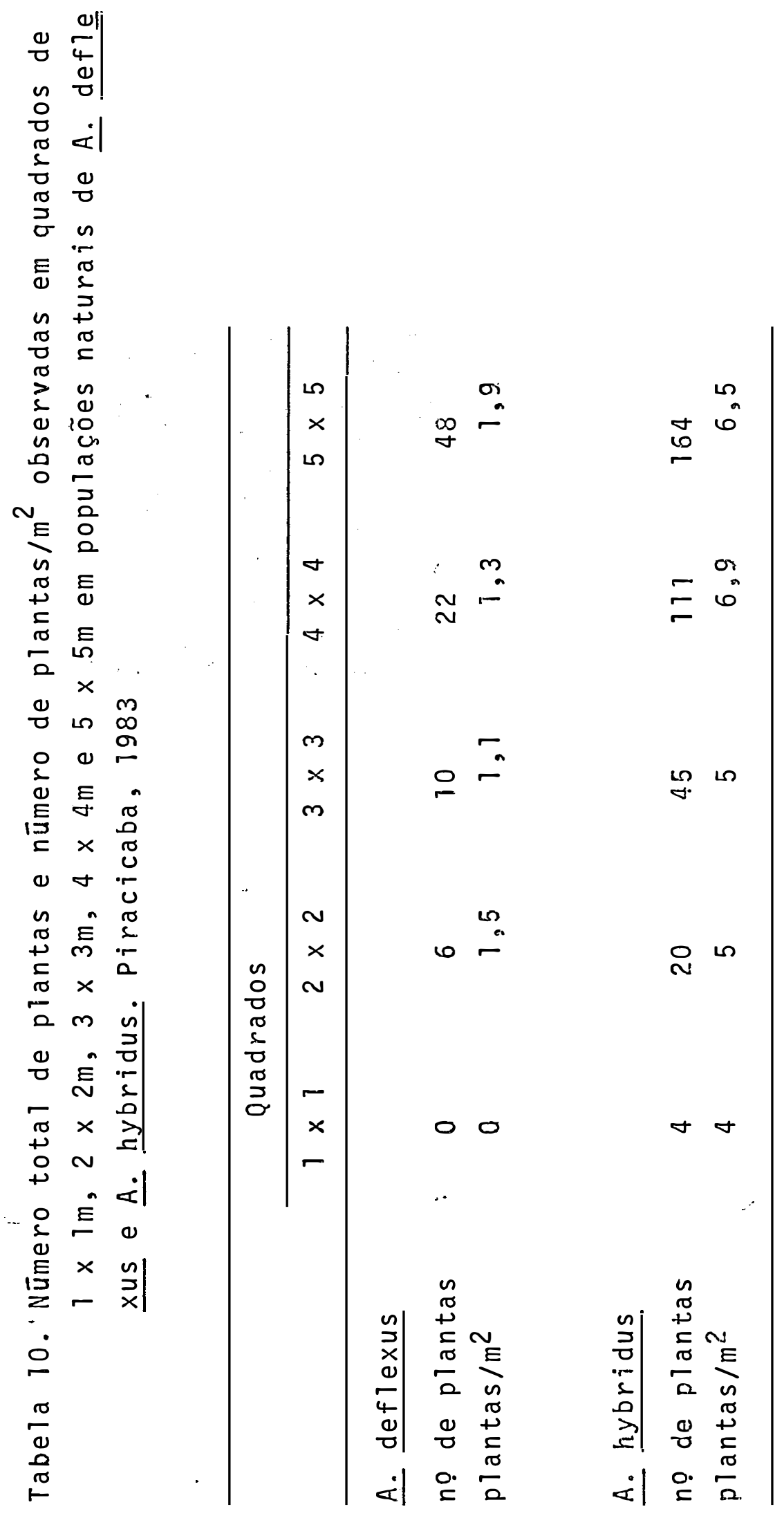




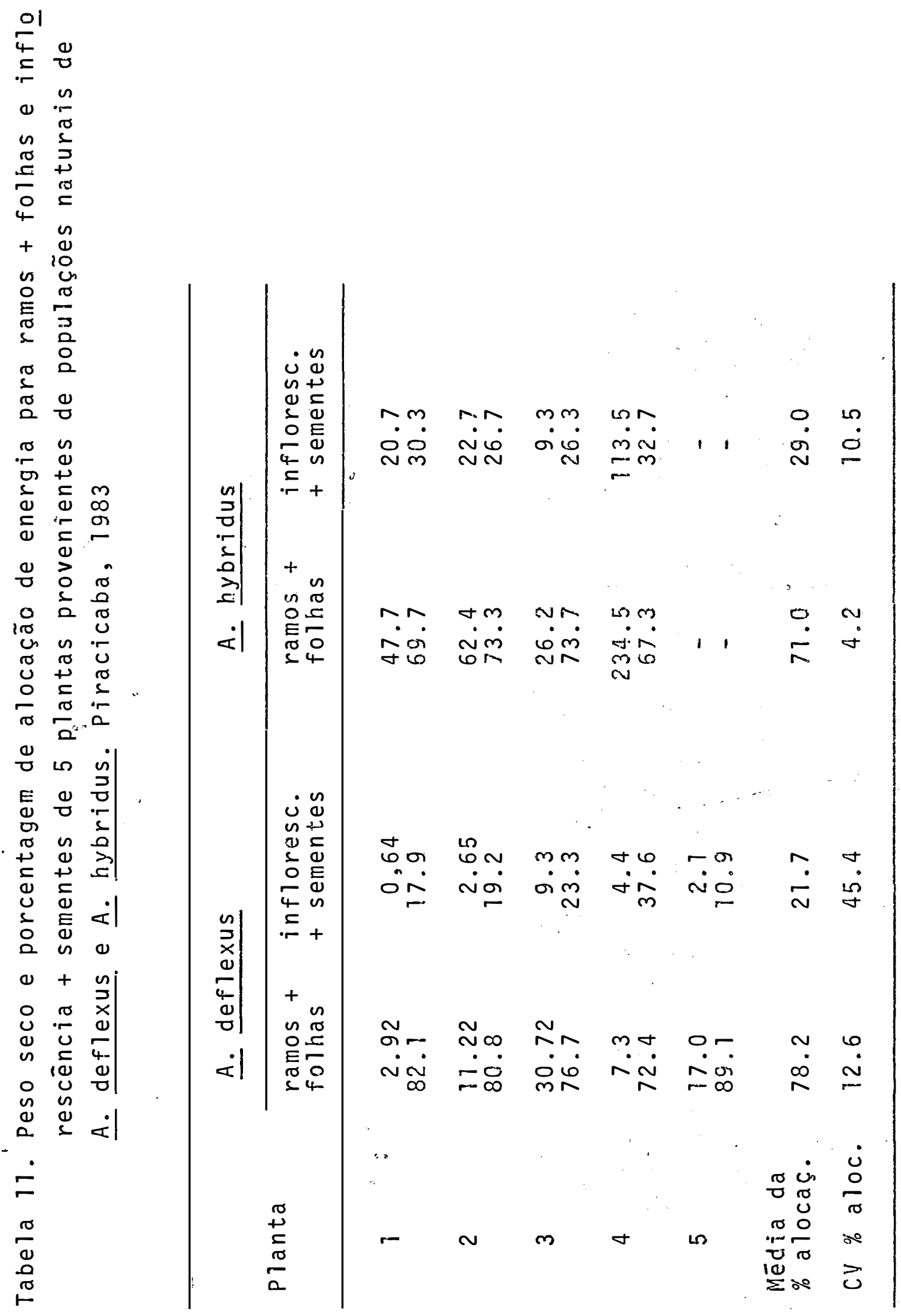




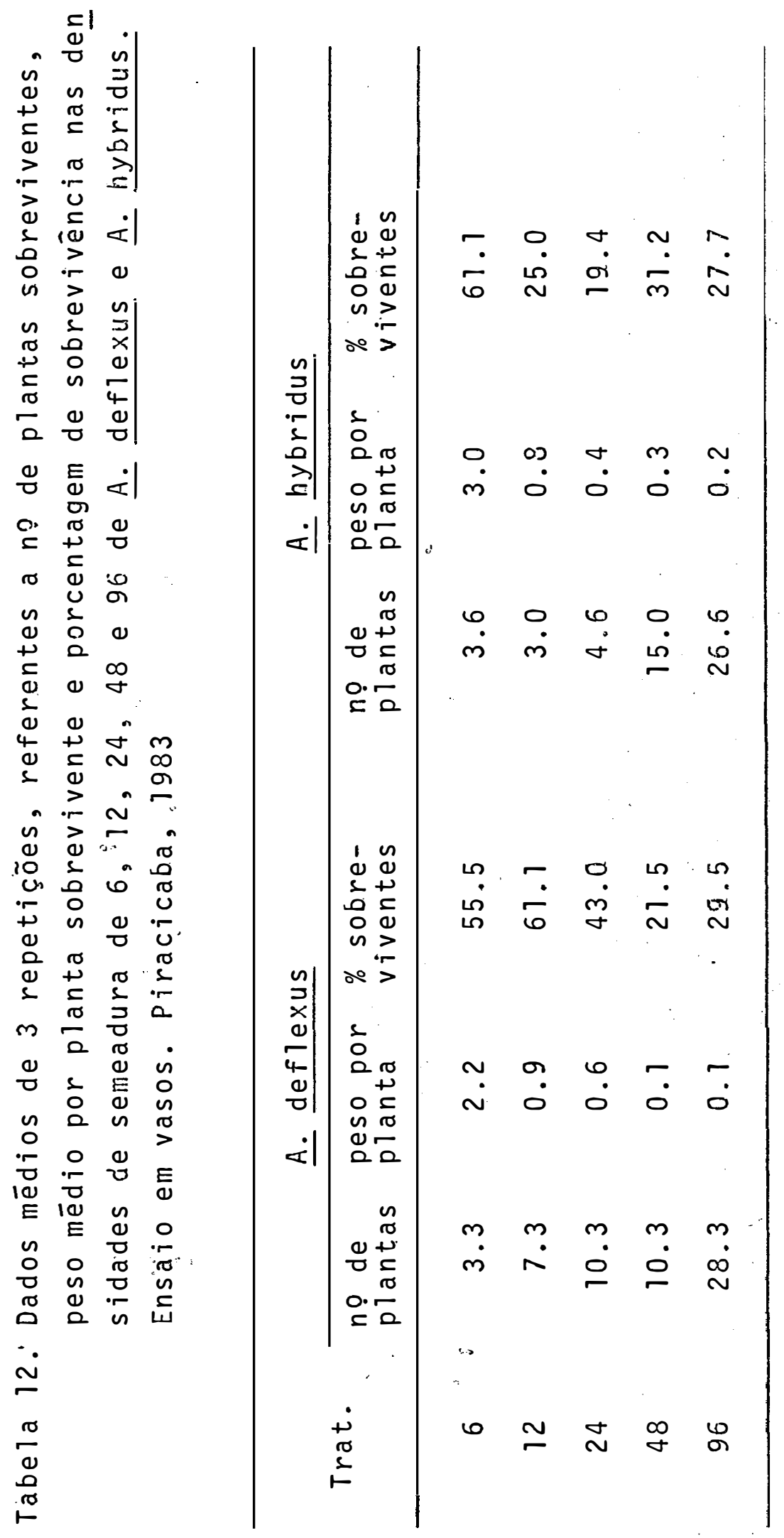




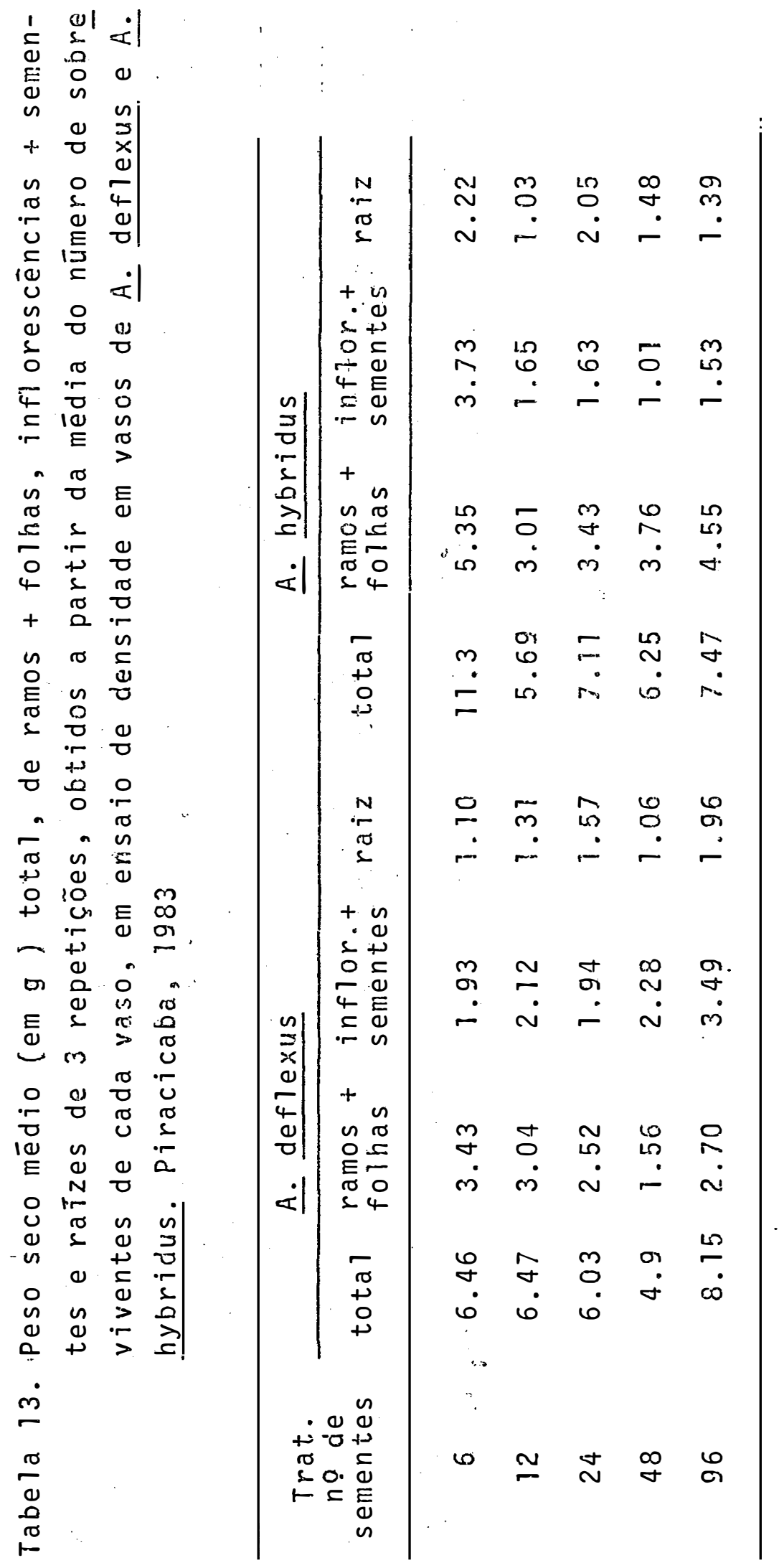



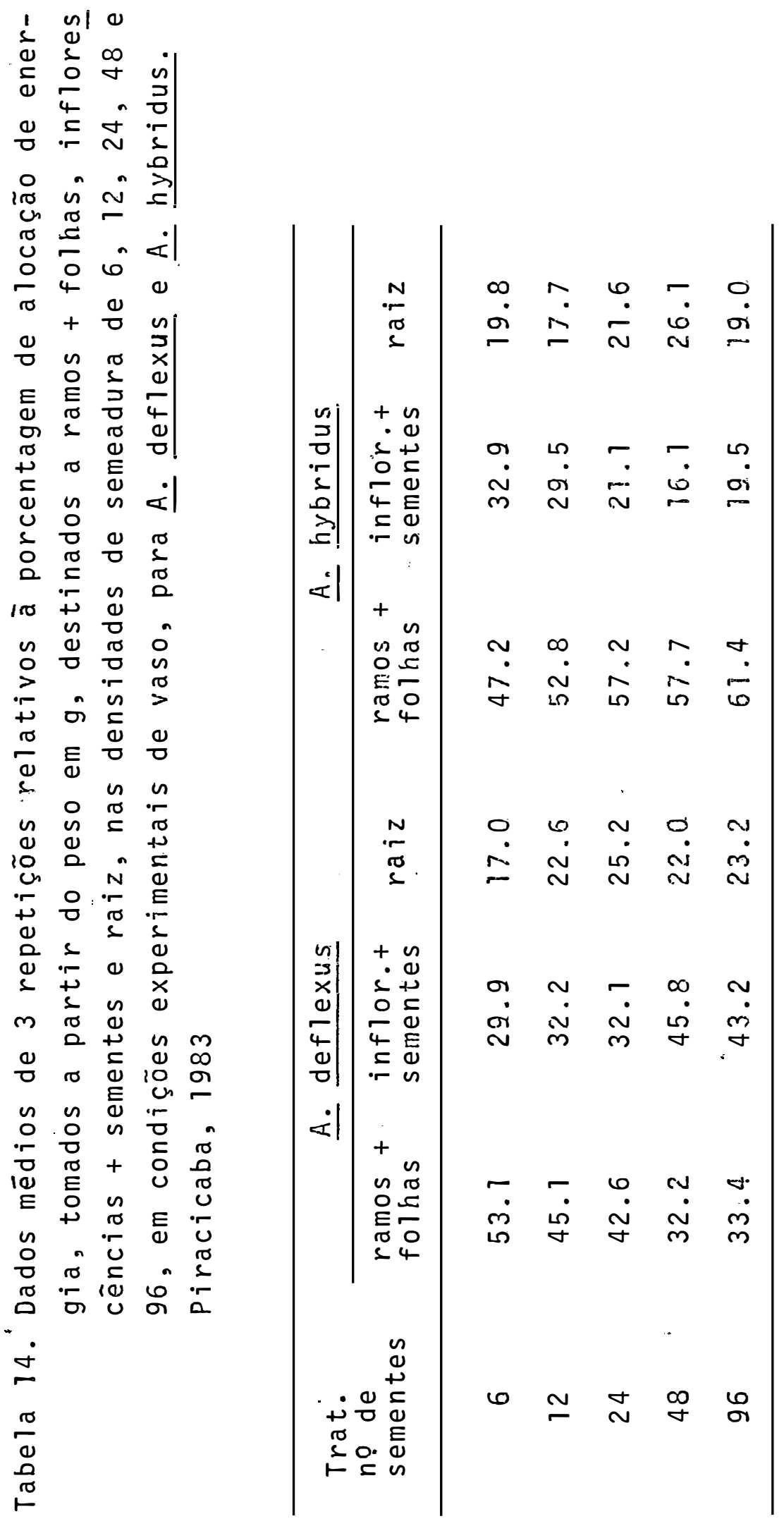


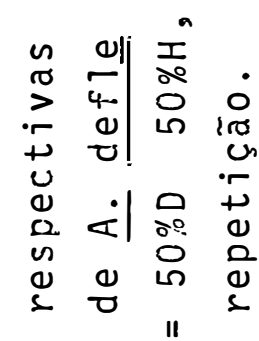

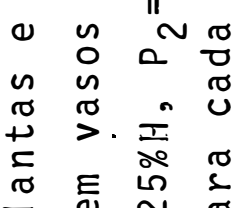

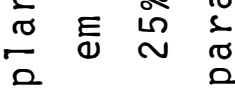

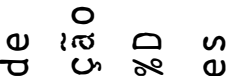

0 म $N$ 开

\&

E

: 웡응

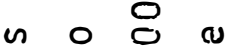

0
0

ir

r.

Q E $\triangle$ H

s. 10 U

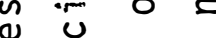

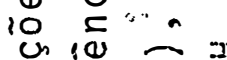

i 10 工

(1) $>0$

으 인

\begin{tabular}{lll|l}
2 & 2 & 0 \\
0 & 0 & 0
\end{tabular}

$m$ u 12

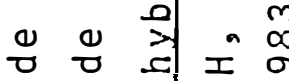

क ज行

न

Id

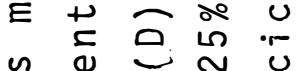

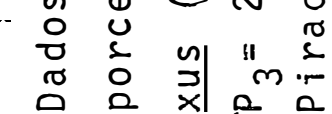

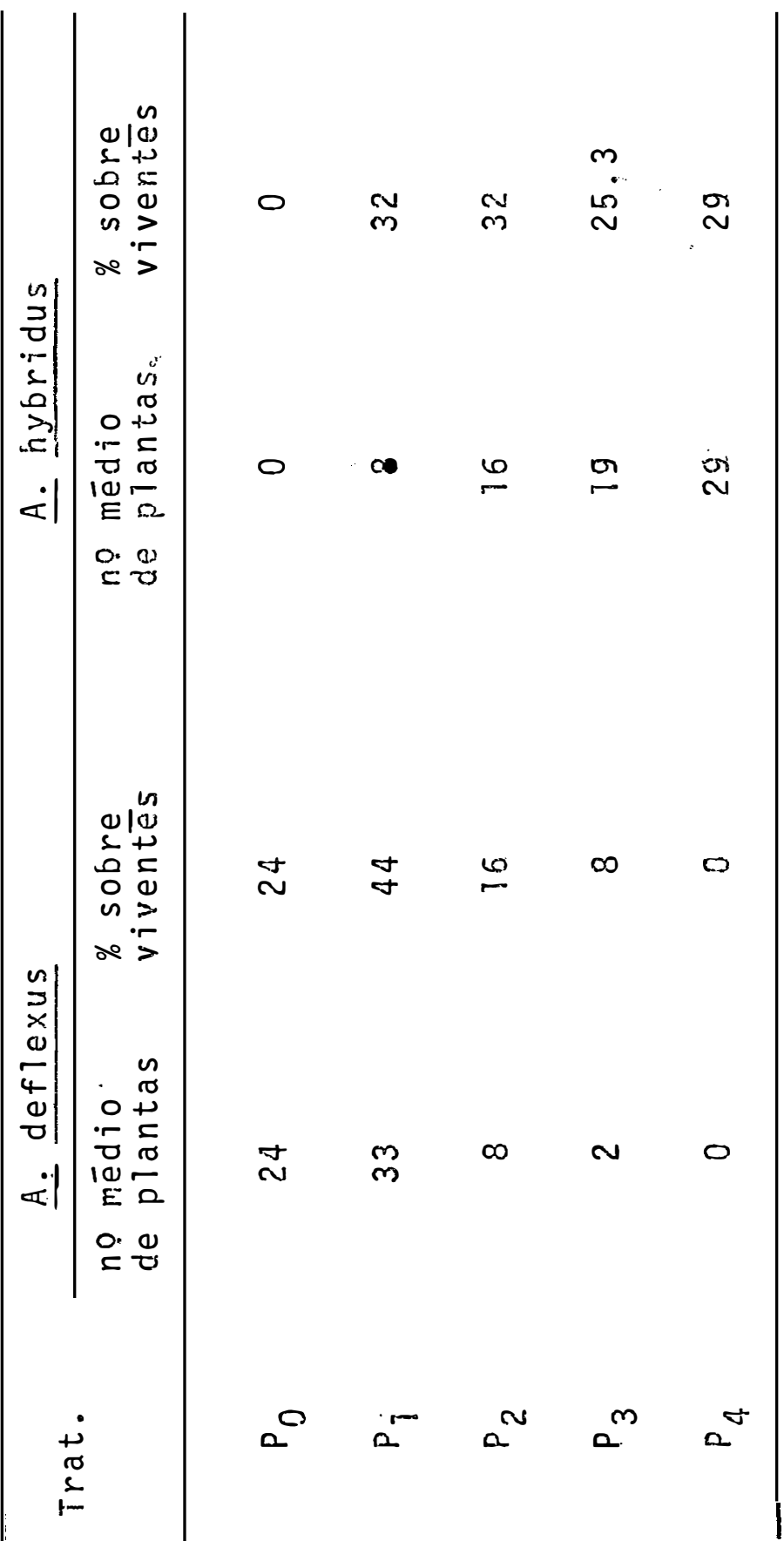

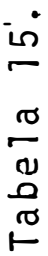




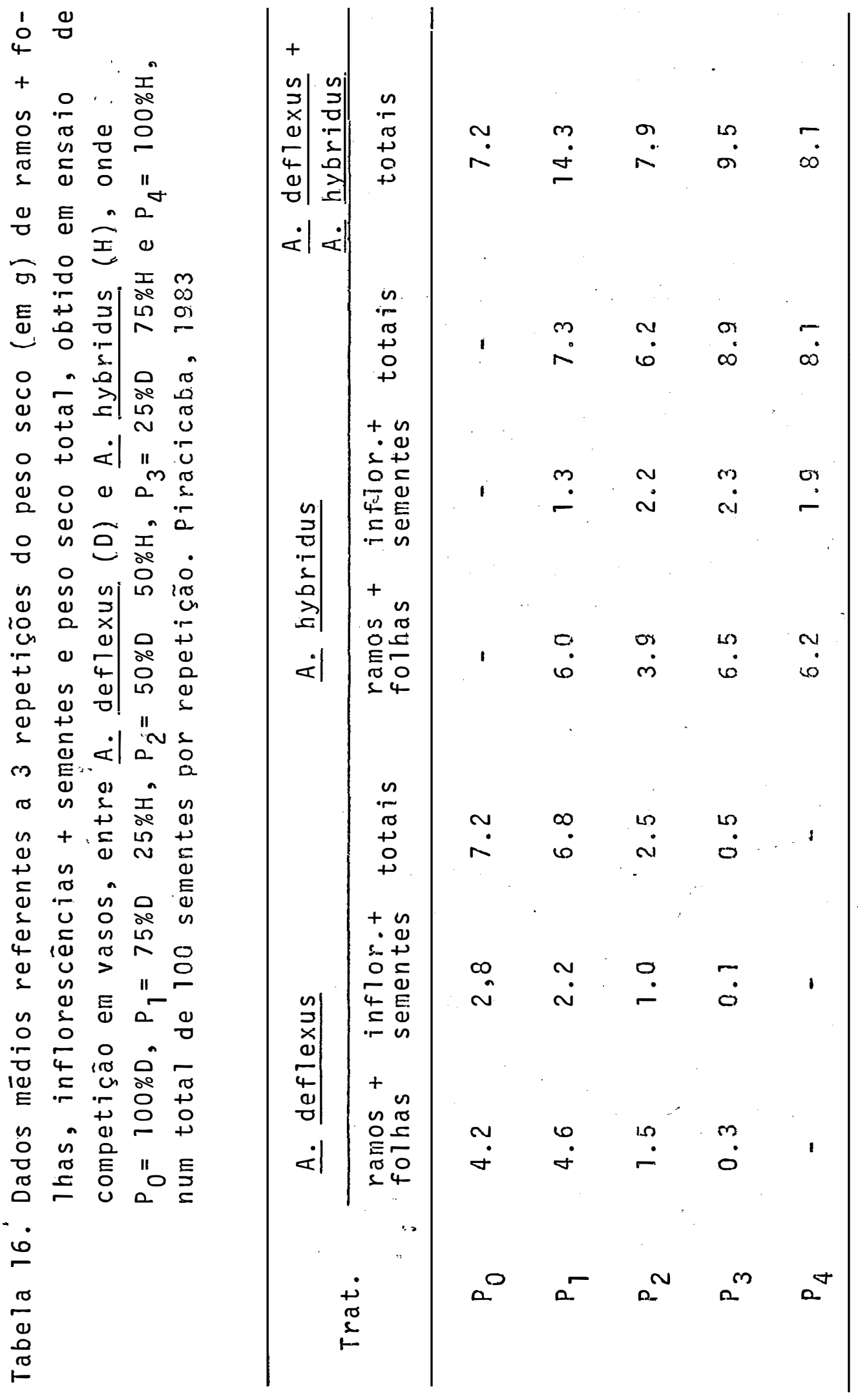



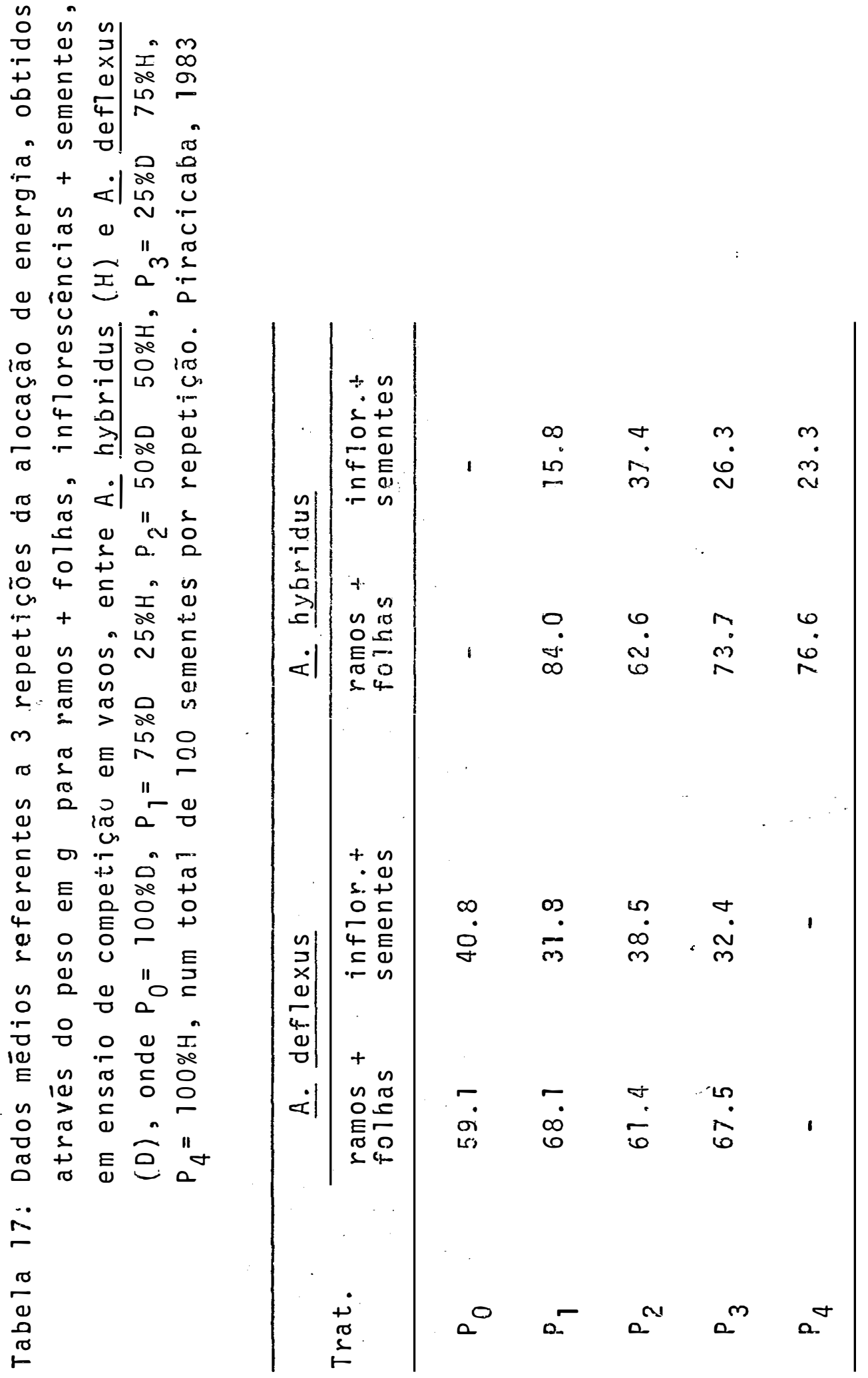


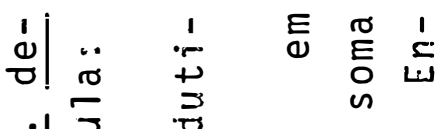

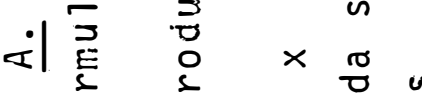

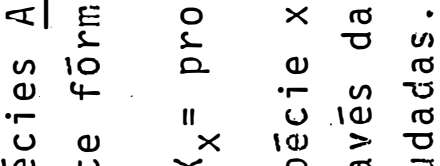

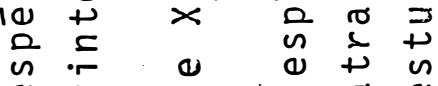

ब כ

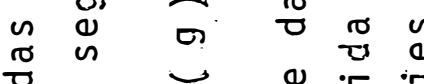

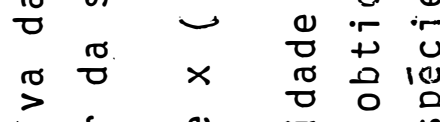

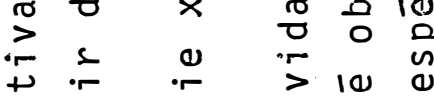

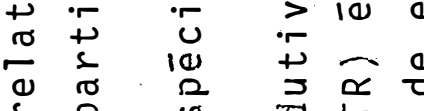

$\therefore$ व ज

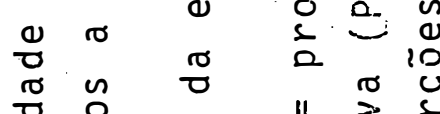

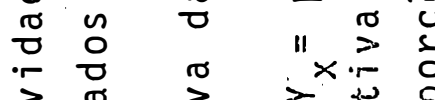

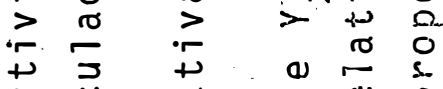

ว 0 r

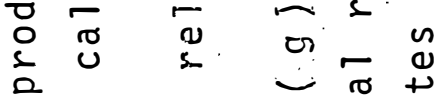

$\therefore$ -

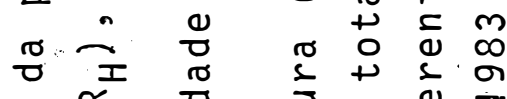

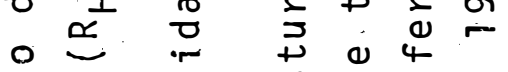

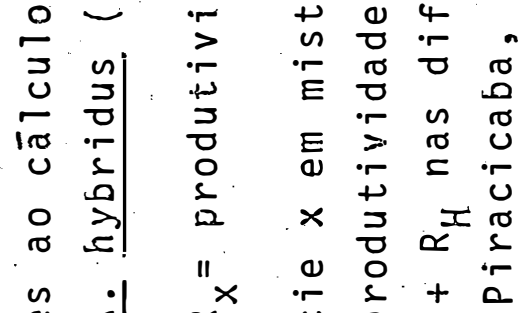

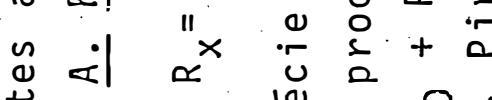

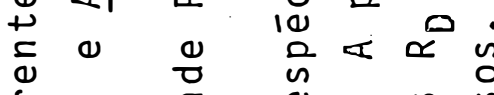

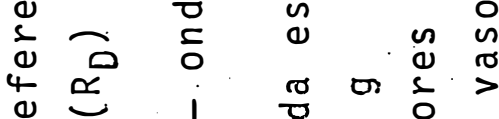

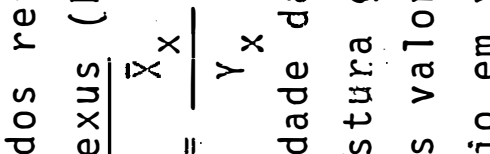

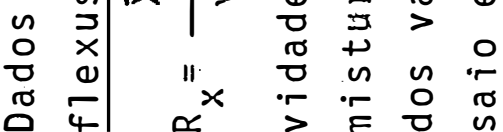

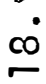

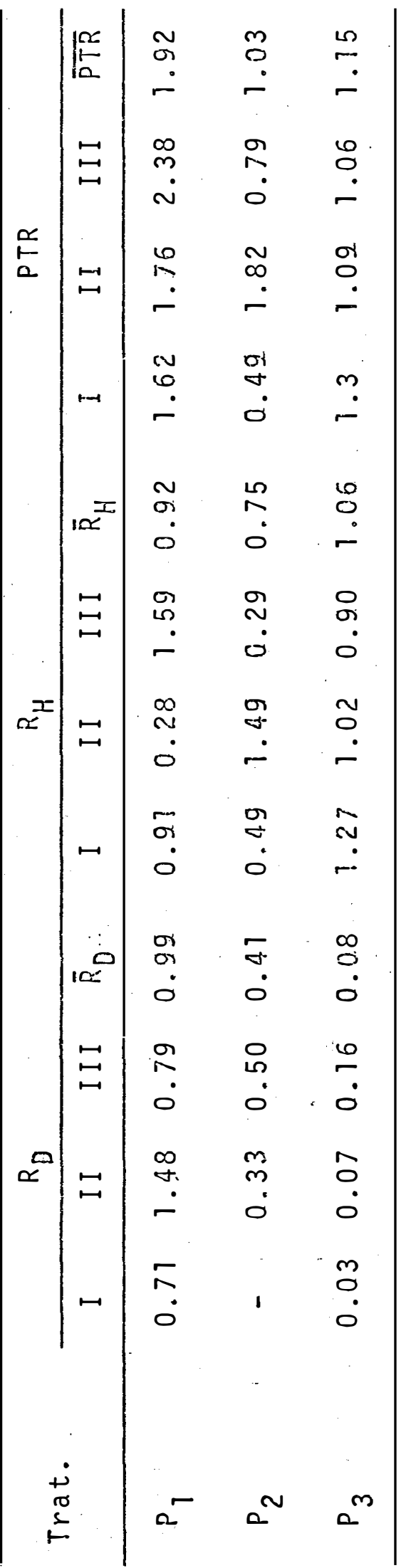

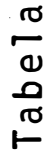




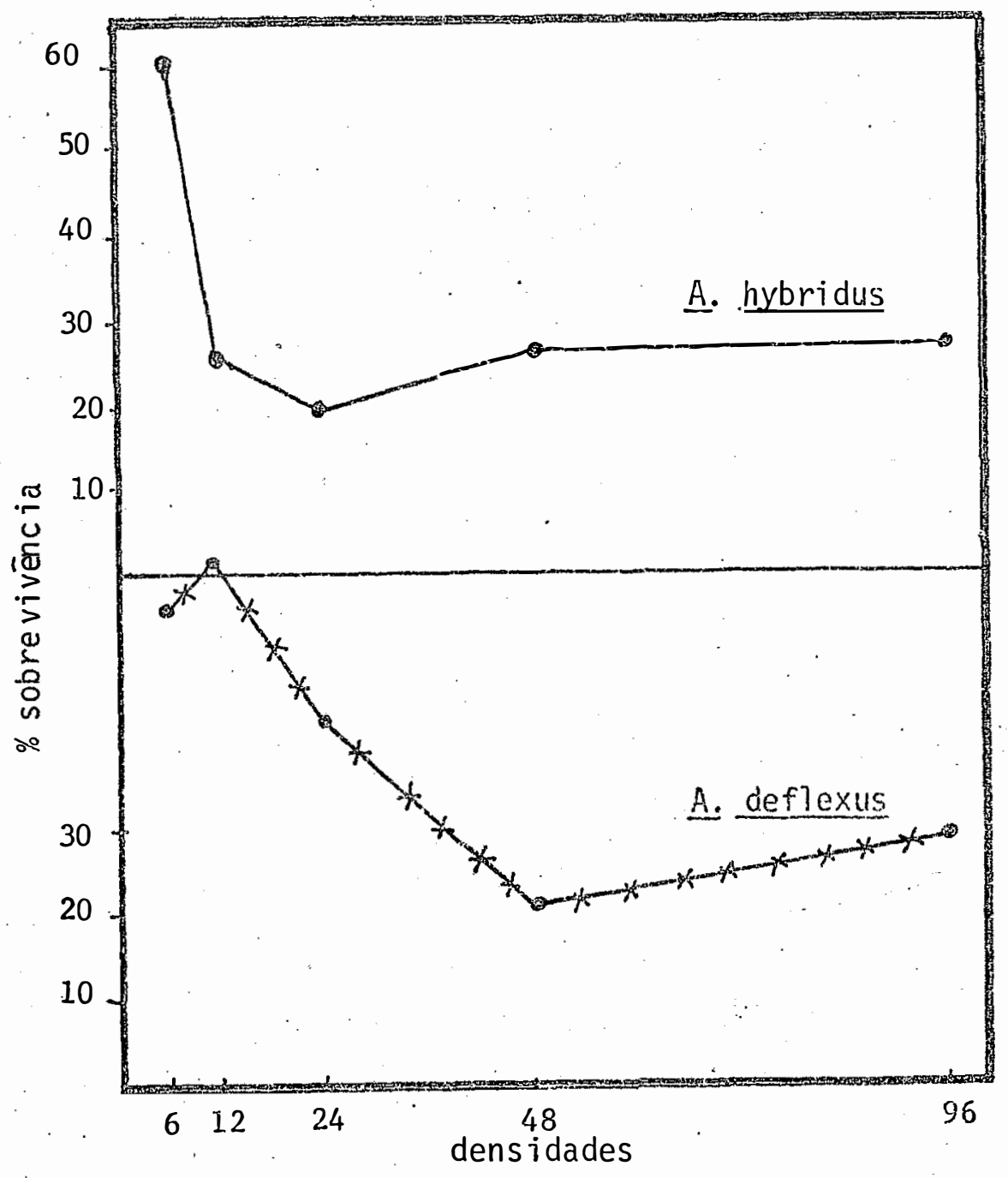

Grāfico 10. Representação grāfica da mēdia da porcentagem de sobrevivência de 3 repetições, em ensaio de densidade em vasos, de A. hybridus e A. deflexus, cujas densidades de semeadura foram $6,12,24$, 48, 96. Piracicaba, 1983. 


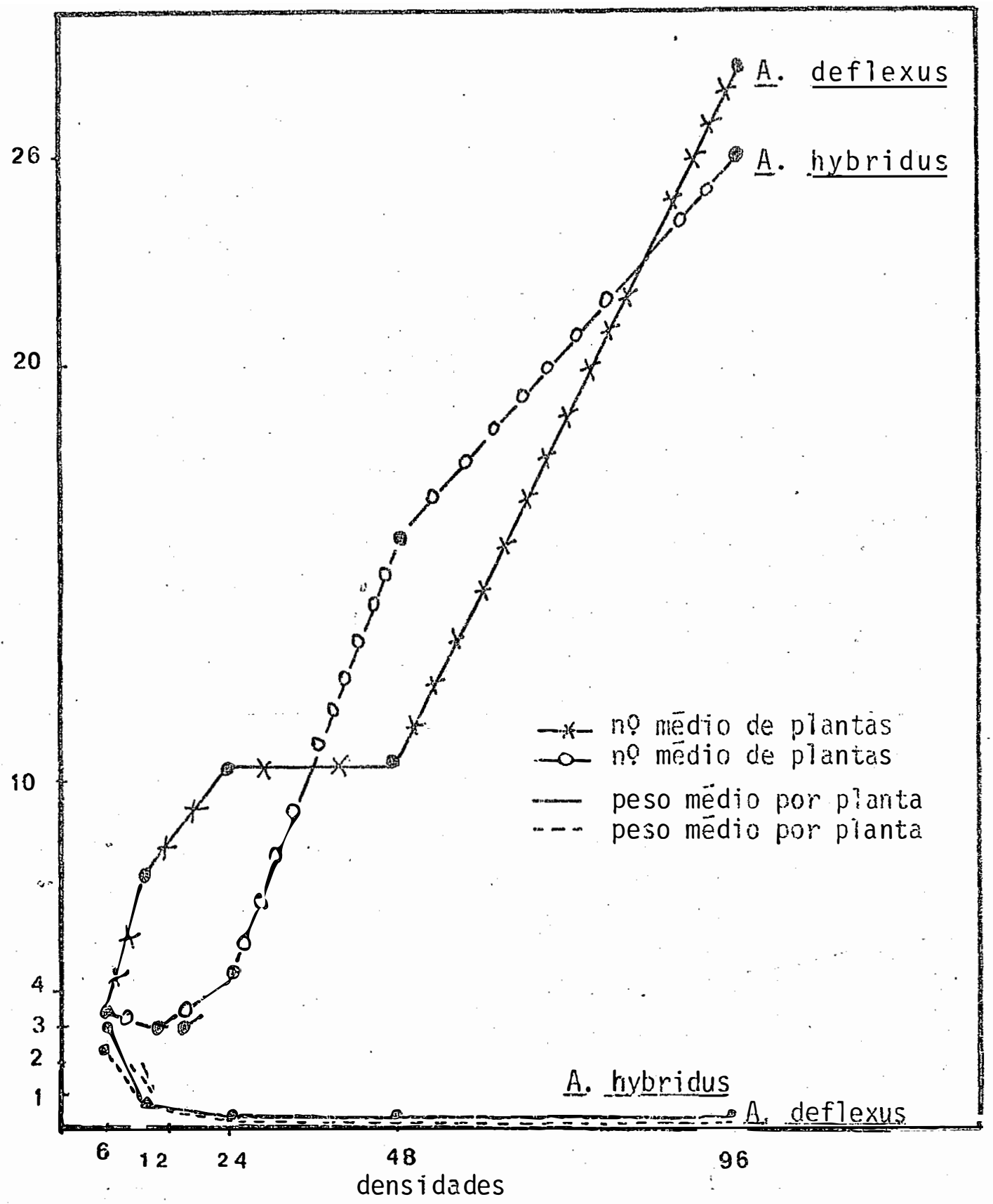

-Grāfico 11. Grā́fico comparativo do nūmero médio de plantas é peso mēdio por planta, referentes à media de 3 re petições, em ensaio de densidade em vasos, de $\underline{A}$. deflexus e A. hybridus, cujas densidades de semea dura foram 6, 12, 24, 48, 96. Piracicaba, 1983. 


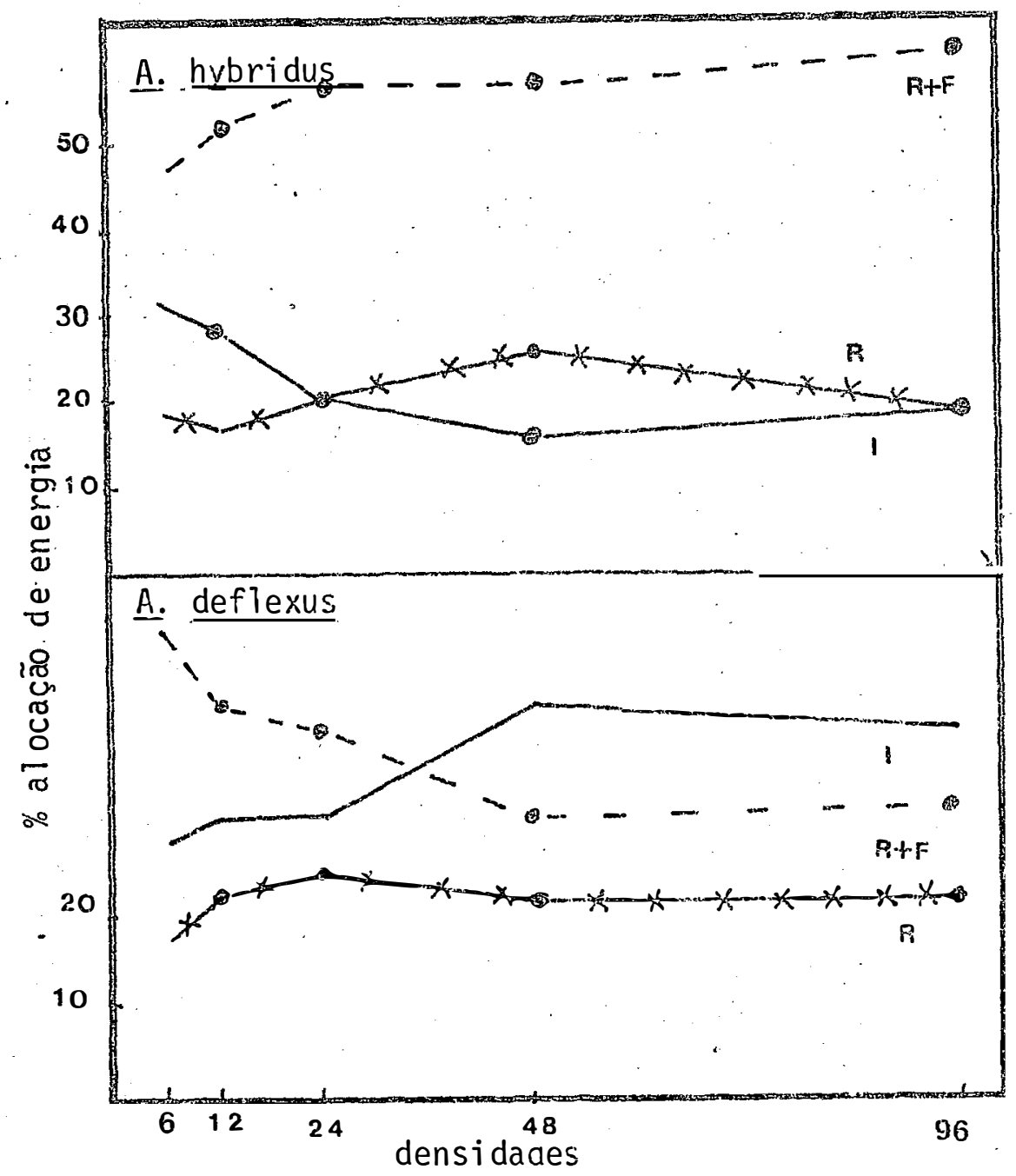

Grāfico 12. Comparação gráfica da alocaçắo de energia em por centagem, obtida atravēs do peso seco médio de 3 repetições, nas diferentes densidades de semeadu ra, em vaso, de $6,12,24,48,96$, para ramos + folhas, inflorescēncia + sementes e raizes de $A$. deflexus e A. hybridus. Piracicaba, 1983. 


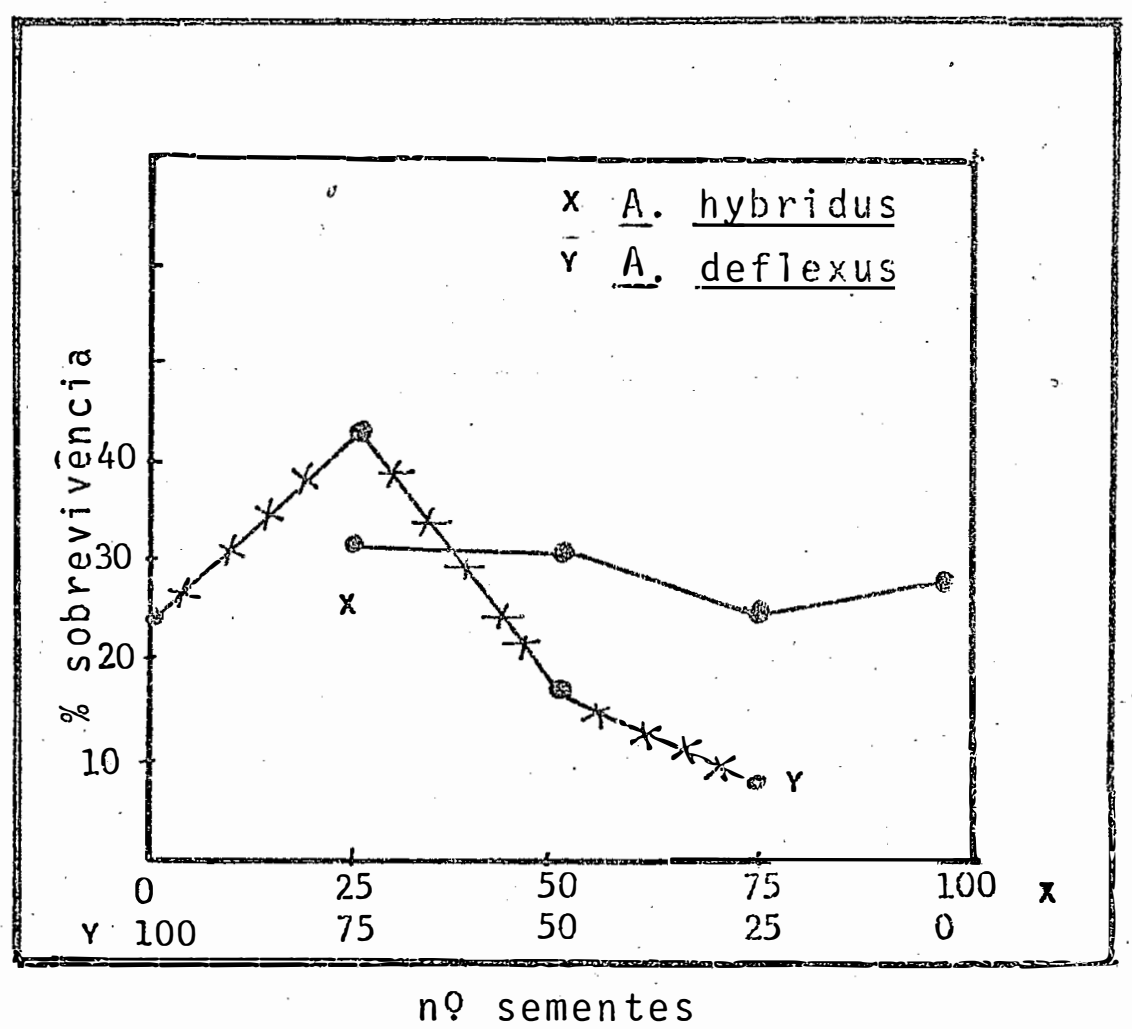

Gräfico 13. Horcentagem de sobrevivēncia mēdia de 3 repetições, ao final. do ciclo em ensaio de competição em vasos de A\% deflexus. (D) e A. hybridus. (H), onde $\mathrm{P}_{0}=100 \% \mathrm{D}, \mathrm{P}_{1}=75 \% \mathrm{D} 25 \% \mathrm{H}, \mathrm{P}_{2}=50 \% \mathrm{D} 50 \% \mathrm{H}, \mathrm{P}_{3}=$ $25 \% \mathrm{D} 75 \% \mathrm{H}, \mathrm{P}_{4}=100 \% \mathrm{H}$, num total de 100 sementes para cada repetição. Piracicaba, 1983. 


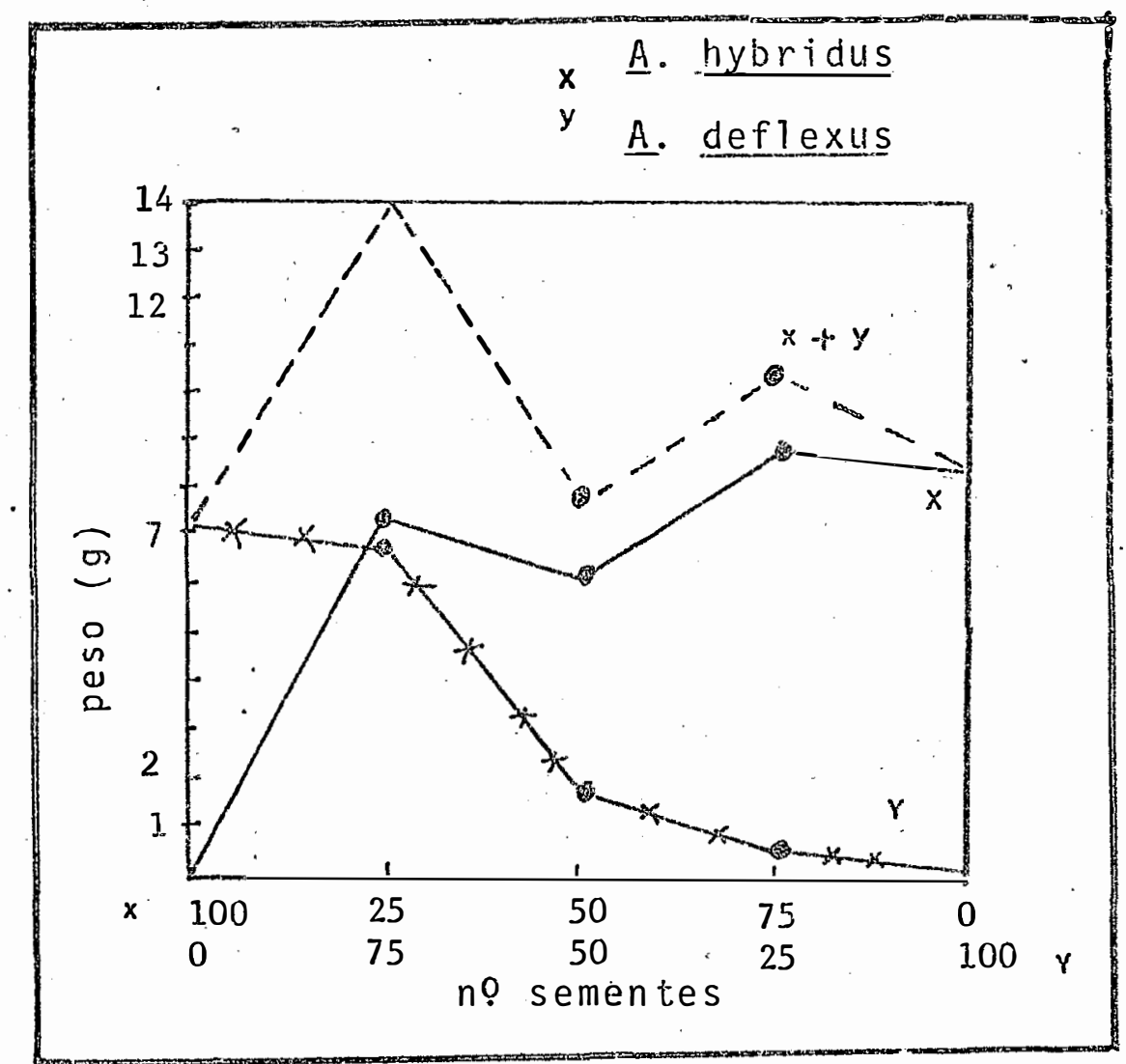

Grāfico 14. Produtividade média de matéria seca total, em gramas, medida ao final do ciclo em ensaio de competição em vasos de A. deflexus (D) e $\underline{A}$. hybridus $(H)$, onde $P_{0}=100 \% \mathrm{D}, P_{1}=75 \% \mathrm{D} 25 \% \mathrm{H}$, $\mathrm{P}_{2}=50 \% \mathrm{D} 50 \% \mathrm{H}, \mathrm{P}_{3}=25 \% \mathrm{D} 75 \% \mathrm{H}, \mathrm{P}_{4}=100 \% \mathrm{H}$, num total de 100 sementes para cada repetição. P $\underline{i}$ racicaba, 1983 . 


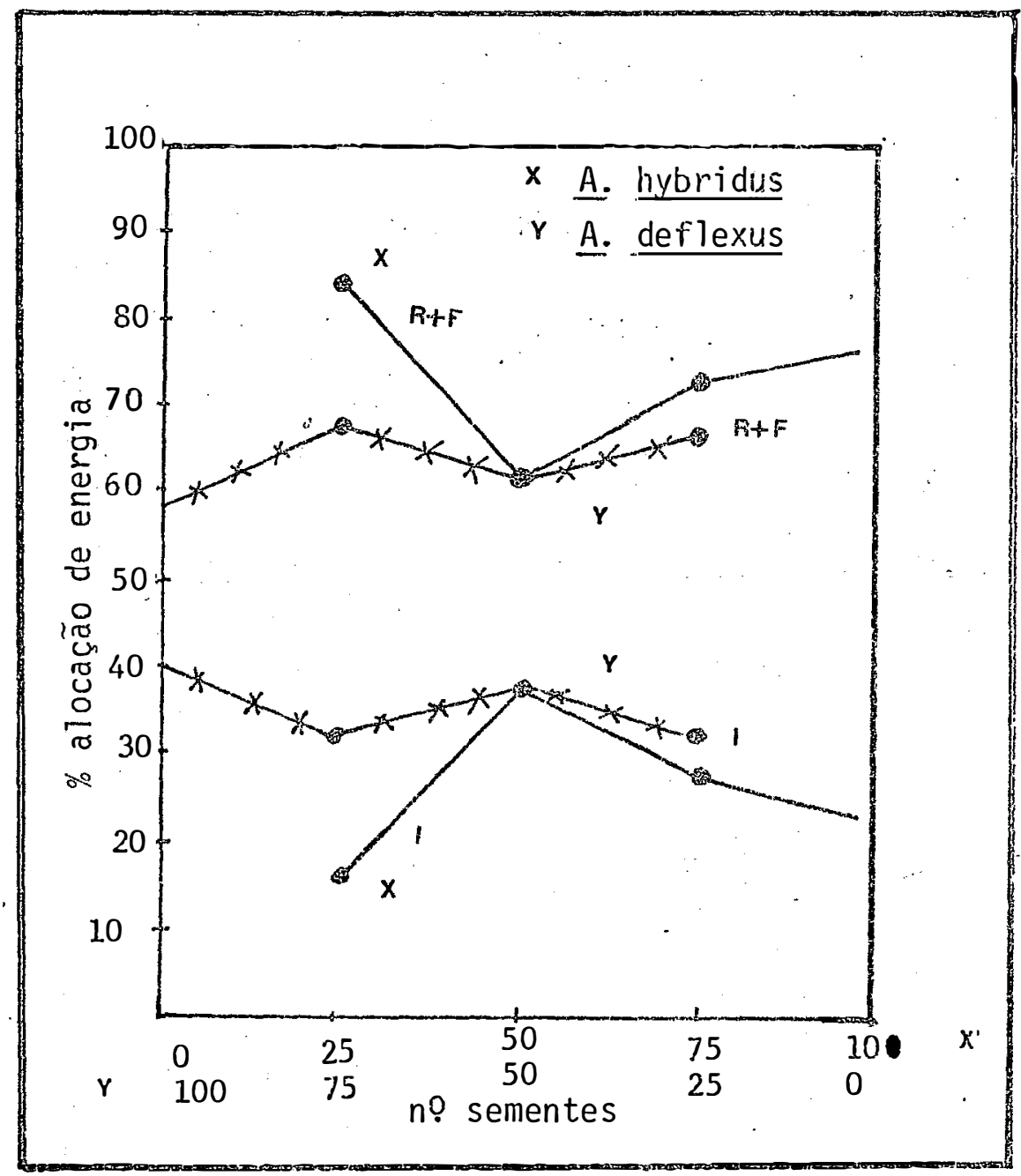

Grāfico 15. Porcentagem média da alocação de energia de 3 repetições, obtidas atravēs do peso seco em gramas, em erisaios de competição, em vasos, entre A. defle. xus (D) e A. hybridus $_{\text {ny }}$ (H), onde $P_{0}=100 \% \mathrm{D}, \mathrm{P}_{1}=75 \% \mathrm{D}$ $25 \% \mathrm{H}, P_{2}=50 \% \mathrm{D} .50 \% \mathrm{H}, P_{3}=25 \% \mathrm{D} 75 \% \mathrm{H}, P_{4}=100 \% \mathrm{H}$, num total de 100 sementes para cada repetição. Piracicaba, 1983. 


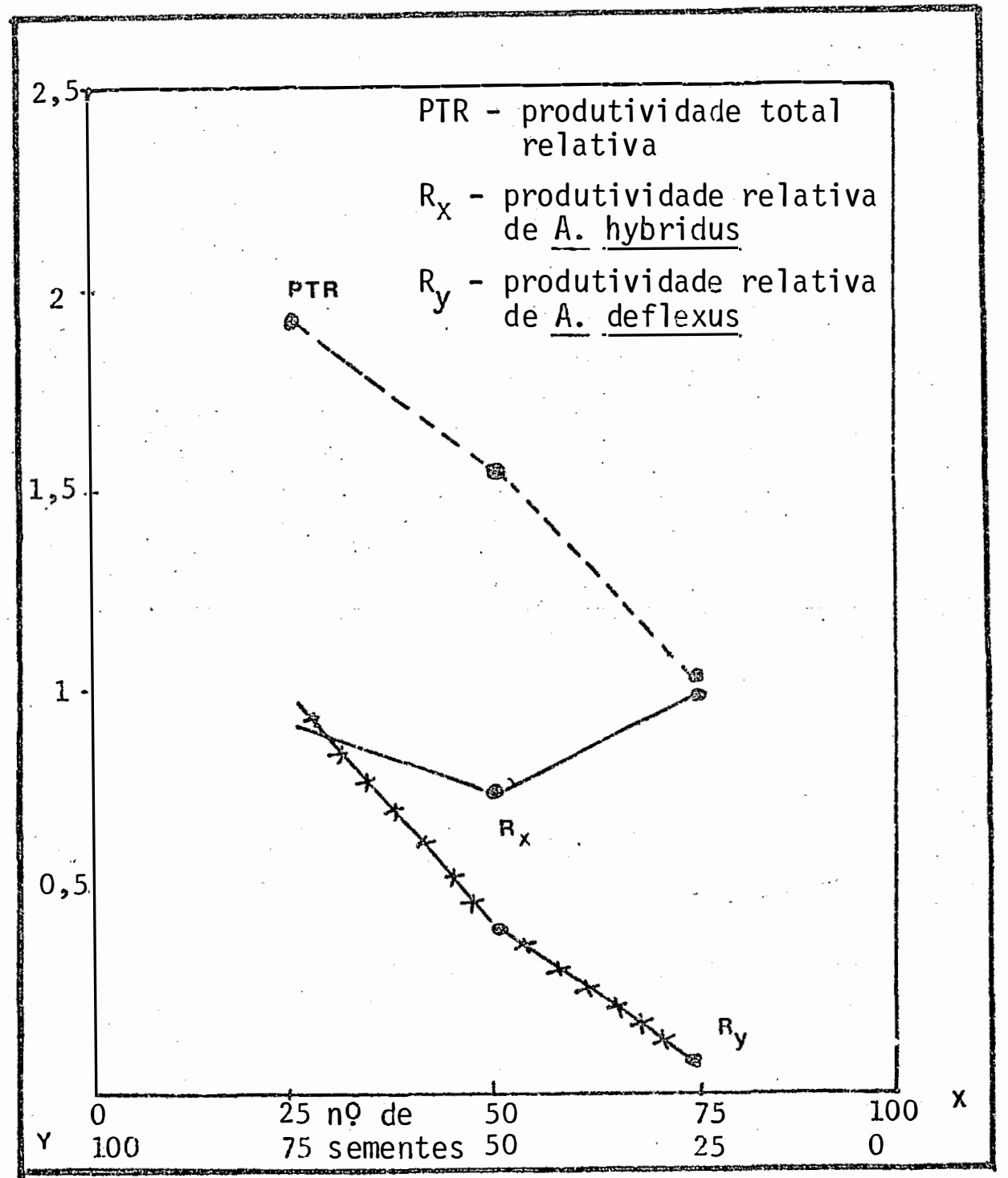

Grāfico. 16. Comparação grāifica da produtividade total relatị va (PTR), produtividade relativa de A. hybridus. (Rx) e produtividade relativa de A. deflexus. (Ry). Ensaio em vasos. Piracicaba, 1983. 
5. CONCLUSÖES

os resultados obtidos no presente trabalho per mitem concluir que:

a. existem semelhanças na duração do ciclo vị tal e época de florescimento para as espécies A. hybridus é A. retroflexus. A espëcie A. viridis caracterizou-se como sendo a espécie mais precoce e a espécie A. spinosus, como a mais tardia, tanto na duração do ciclo vital como no início do fiorescimento;

b. os maiores esforços reprodutivos foram apresentados pela espécie mais precoce (A. viridis), enquanto os menores esforços foram da espécie mais tardia (A. spi nosus):

c. existem populações naturais contituĩdas das espécies A. deflexus e A. hybridus. Nestas, são encontrados maiores números de individuos de $\underline{A_{2}}$ hybridus do que de $\underline{A_{\text {c de }}}$ flexus;

d. nos ensaios de densidade em vasos, a espēcie A. deflexus mostrou precocidade no início da germinação, florescimento e duração do ciclo vital, em comparação com a espécie A. hybridus; 
e. a severidade do "self-thinning" é mais acen tuada para o $\underline{A}$. hybridus em condições de crescentes pressões intraespecíficas em vasos, do que para o A. deflexus;

f. a espécie A. deflexus responde ao stress in traespecifico alocando maiores quantidades de biomassa para atividades reprodutivas, enquanto o A. hybridus responde alo cando frações maiores de sua biomassa para atividades vegeta tivas;

g. a severidade do "self..thinning" em condições de competição interespecĩfica em vasos, ē mais intensa para 0 A. deflexus;

h. as espécies A. deflexus e A. hybridus deman dam, para sua sobrevivência, de diferentes recursos limitantes do ambiente,

i. no que se refere à captação da energia solar, as duas espëcies se posicionam espacialmente de tal for ma que o A. hybridus ocupa estratos superiores, atravēs de um marcante crescimento vertical e o A. deflexus, um posicio namento prōximo ao solo e crescimento do tipo radial, que per mite uma menor captura da energia solar. 


\section{LITERATURA . CITADA}

ABRAHAMSON, W. G., 1979 - Patterns of resource allocation in wild flower populations of fields and woods. American Journal of Botany, 66, 71-79.

ABRAHAMSON, W. G. e M. GADGIL, 1973 - Growth form and reproductive effort in golden rods (Solidago, Compositae). American Naturalist, 107, 651-661.

BARRIGA, J. P., 1979. Autoecologia de Stylosanthes humilis HBK: Avaliação da variabilidade morfológica e estudos de biologia da semente. Piracicaba, ESALQ, 90 p. (Dissertação de mestrado).

BERENDSE, F., 1981 - Competition between plant population with different rooting depths II. Pot. Experiments. 0ecologia, 48, 334-341.

BIALOSKORSKI, S. e P. S. MARTINS, 1981 - Influência de alguns fatores ecológicos na germinação de espécies de Amaranthus. Relatório Científico do Departamento de Genētica - ESALQ - Piracicaba, 1ㄷ, 29-34. 
BRADSHAW, A. D., M. J. CHADWIDK, D. JOWETT E R. W. SNAYDON, 1964 - Experimental investigations into the mineral nutrition of several grass species. IV.J. Ecol., 52, $665-676$.

CLEMENTS, F. E. e G.W. GOLDSMITH, 1924 - The phytometer method in ecology. Carnegie Inst. Wash. Publ., 356 , $1-106$.

CLEMENTS, F. E. e J. E. WEAVER, 1924 - Experimental vegetation. Carnegie Inst. Wash. Publ. 355, $1-172$.

COONS, M. P., 1981 - 0 gênero Amaranthus em Minas Gerais. Experientiae, 27, 115-158.

DONALD, C. M., 1951 - Competition among pasture plants. I Intra-specific competition among annual pasture plants. Aust. J. Agric. Res., 2, 355-376.

DOWNTON, W. J., 1973 - Amaranthus edulis a high iysine grain amaranth. World. Crops, 25. (1), 20.

ELIAS, J., 1977 - Food value of amaranth greens and grains. In Proceedings of the First Amaranth Seminar, Maus., Pensylvania, EUA. Rodale Press, p. 17-31.

ELLERN, S. J., J. L. HARPER e G. R. SAGAR, 1970 - A - comparative study of the distribution of the roots of Avena fatua e A. strigosa in mixed stands using a. ${ }^{14} \mathrm{C}$ labelling technique. J. Ecol. 58, 865-868.

EVANS, G. C., 1972 - The quantitative analyses of plant growth Univ. Calif. Press, p. 734.

GADGIL, M. e 0. T. SOLBRIG, 1972 - The concept of $r$ and $k$ 
selection: evidence from wild flowers and some theoretical considerations. American Naturalist, 106, 592-597.

GAINES, M. S.; K. J. VOGHT; J.L. HAMRICK e J. CALDWELL, 1974 - Reproductive strategies and growth patterns in sunflowers (Helianthus). American Naturalist, 108; 889-894.

GIBSON, I. A. S., 1956 - Sowing density and damping-off in pine seedlings. E. Afr. Agric. J., 21, 183-188.

GOMES, P. F., 1978 - Curso de Estatĩstica Experimental, 8a. ed. Piracicaba - Livraria Novel S/A, $430 \mathrm{p}$.

GREEN, J. 0., H. J. LANGER e T. E. WILLIAMS, 1952 - Sources and magnitudes of experimental errors in grazing trials. In: Proceedings of the VI International Grassland Congress, State College, Penn, V. a, p. 1374.

GREEN, R. F., 1980 - A note on k-selection. American Naturalist, 116, 291-296.

GRIME, J. P. e D. W. JEFREY, 1965 - Seedling stablishments in vertical gradients of sun light. J.Ecol. $\underline{5}$, $621-642$.

GRIME, J. P. e R. HUNT, 1969 - Relative growth rate comparisons for plant ecology. American Naturalist, 102 , 595-597.

GRUBBEN, G. J. H., 1976 - The cultivation of amaranth as a tropical leaf vegetal with special reference to South Dohomey. Amsterdan, Netherland, Dept. of Agricultural Research. Koninkliijk. Instituut voor de Tropen, $207 \mathrm{p}$. (Communication 67). 
HARPER, J. L., 1961 - Aproaches to the study of plant competition. Symp. Soc. Exp. Biol., 15, 1-39.

HARPER, J. L. e D. GADGIL, 1961 - Experimental studies of the mortality and plasticity of a weed. Weeds Res. I, 91-104.

HARPER, J. L. e J. OGDEN, 1970 - Reproductive strategy of higher plants. The concept of strategy with special reference to Seneciovulgaris L. J. Ecol. 58, 681-698.

HARPER, J. L., 1977 - Fopulation Biology of plants. American Press, $862 \mathrm{p}$.

HAUPTLI, H. e S. K. JAIN, 1978 - Byosystematics and agronomic potential of some weedy and cultivated amaranth. Theor. App 1. Genet. 52, 177-185.

HAUPTLI, H. e S. K. JAIN, 1980 - Potential of Amaranth as human and animal food. Western Chapter Meeting

HICKMAN, J. C., 1975 - Environmental unpredictability and plastic energy allocation strategies in the annua? Polygonum cascadense (Polygonaceae). J. Ecol. 63, $689-701$.

HICKMAN, J. C.e L. F. PITELKA, 1975 - Dry weight indicates energy allocation in ecological strategy of plants. 0ecologia, 21, $117-121$.

HOLLIDAY, R. J., 1960 - Plant population and crop yiel. Fld. Crop Abstr. 13, 159-167.

HIROI, T. e M. MONSI, 1966 - Dry-matter economy of Helianthus annuus communities grown at varyng densities and light intensities. J. Fac. Sci. Univ. of Tokyo, 9, 241-285. 
HUNZIKER, A. T.,., 1943 - Las species alimenticias de Amaranthus y Chenopodium cultivadas por los indios da América. Revista Argent. Agron., 10, 297 …355.

KIRA, T., H. OGAWA e K. SHINOZAKI, 1953. Intraespecific competition among higher plants. I. Competition density - yield inter-relationships in regularly dispersed populations. J. Inst. Polytech. Osaka, Cy. Univ. 4, 1-16.

KOYAMA, h. e T. KIRA, 1956 - Intraspecific competition among higher plants: VIII Frequency distribution of individual plant weight as affected by the interaction between piants. J. Inst. Polytech. Osaka Cy. Univ. ㄱ, 73-93.

LEITAO FILHO, H., 1968 - Espëcies de Amaranthus que ocorrem como invasoras no município de Campinas. Bragantia 27, 477-497.

MCARTHUR, R. H. e E. O. WILSON, 1967 - The teory of Island Biogeography, Princepton University Press, $149-750$.

MCGILCHRIST, C. A., 1965 - Analyses of competition experiments. Biometrics, 21, 975-985.

McGILCHRIST, C. A. e B. R. TRENBATH, 1971 - A revised analyses of competition experiments. Biometrics, 27 , $659-671$.

MARTINS, P. S. e N. A. VELLO. 1983. Performance and variability of agronomic characters in populations of Stylosanthes guianensis. (Aubl). S. W. In. Proceedings of the XIV International Grassiand Congress, Lexington, Kentucky, 196-198. 
MARX, J. L., 1977 - Amaranth: a comeback for the food of the Aztecs? Science, $\underline{198,40 .}$

NAYLOR, R. E. L., 1972 - Aspects of the population dynamics of the weed Alopecurus myosuroides. Huds. in winter cereal crops. J. Appl. Ecol., 9, 127-139.

OBEID, M.; D. MACHIN e J. L. HARPER, 1967. Influence of density on plant to plant variation in Fiber Flax, Linum. usitatissimum L. Crop Science, $7,471-473$.

OGDEN, J., 1970 - Plant population structure and productivity Proc. N. Z. Ecol. Soc. 17, 1-9.

OGDEN, J., 1974 - The reproductive strategy of higher plants. II. The reproductive strategy of Tussilago farfara L. Journal of Ecology, 62, 291-324.

PAL, M. F., 1972 - Evolution and improvement of cultivated amaranthus. I Breeding system and infiorescence structure Proc. Indian Nat1. Sci. Acad. 38-8, 28-37.

PAL, M. e T. N. KHOSHOO, 1973 - Evolution. and improvement of cultivated amaranth. VI Cytogenetic relationships in grain types. Theor. Appl. Genetics, 43, 242-251.

PAL, M. e T. N. KHOSHOO, 1974 - Evolutionary studies in world crops: diversity and change in Indian Sub. continent. J. B. Hutchinson. Ed. Cambridge Univ. Press p. $129-137$.

PARSONS, R. F., 1968 - The significance of growth rate comparisons for plant ecology. American Naturalist, 102, 595-597. 
PIANKA, E. R., 1970 - On $r$ and $k$ selection. American Naturalist, 104, 592-597.

PITELKA, L. F., 1974 - Comparative energy allocation in annual and perenial lupines (lupinus: leguminosae)

PhD. Dissertation, Stanford University.

SAKAI, K. I., 1953 - Studies on competition in plants. I analyses of the competitional variance in mixed plant population. Jap. J, Bot. 14, 161-168.

SAKAI, K. I., 1955 - Competition in plants and its relation to selection. Cold Spring Harbor Symp. Quant. Biol. 20, $137-157$.

SAUER, J. D., 1950 - The grain Amaranth: a survey of their history and classification. Ann. Mo. Bot. Gard., 37, $561-623$.

SAUER, J. D., 1967 - The grain Amaranths and their relatives: a revised taxonomic and geografic survey. Ann. Mo. Bot. Gard., 54, 103-137.

SCHAFFER, M. W., 7974 - Optimal reproductive effort in fluctuating environments. American Naturalist, 108 , $782-817$.

SHINOZAKI, K. e KIRA, T., 1956 - Intraspecific competition among higher plants. VII. Logistic theory of the $\mathrm{C}-\mathrm{G}$

- effect. J. Int. Polytech Osaka, Cy Univ. I, 35-72.

SOARES, R. S., 1980 - Ecologia de populações de Stylosanthes guianensis. (Aubl.) S. W. (Leguminosae Papilionoideae). Piracicaba, ESALQ, 96 p. (Dissertação de doutorado). 
STANDLEY, P. C., 1917 - Amaranthus North Amer. Flora 21 (pt 2), 99-119.

SMITH, L. B. e R. J. DOWNS, 1972 - Amarantāceas. Em Reitz, R. ed. Flora Ilustrada Catarinense. Pt I. AMAR. Itajai, $110 \mathrm{p}$.

SUKATSCHEV, W. N., 1928 - Plant communities. Nauk, Moscow.

THELLUNG, A., 1914 - Amaranthus. Em Ascherson, P. e Graeber,P. Eds. Synopsis DER. Mitteleuropäischen Flors $\underline{5}$ (I), 255-356.

TREMBATH, B. R. e J.L. HARPER, 1973 - Neighbour effects in the genus Avena. I. Comparison of crop species. J. Appl. Ecol., 10, 379-400.

WILLIAMS, E. J., 1962 - The analyses of competition experiments. Aust. J. Biol. Sci. 15, 509-525

WIT, C. T: de, 1960 - On competition.Versl. Landbouwk. ourderz, $66,1-82$.

WIT, C. T. de; P. G. TOW e G. C. ENNIK, 1966 - Competition between legumes and grasses. Versl Lanabouwt Ouderz, $687,3-30$

YODA, K., T. KIRA, H. OGAWA e K. HOZUMI, 1963 - Self thinning in overcrowded pure stands under cultivated and natura?

- conditions. J. Biol. 0saka Cy. Univ. 14, 107-129. 